\title{
UNODC
}

United Nations Office on Drugs and Crime

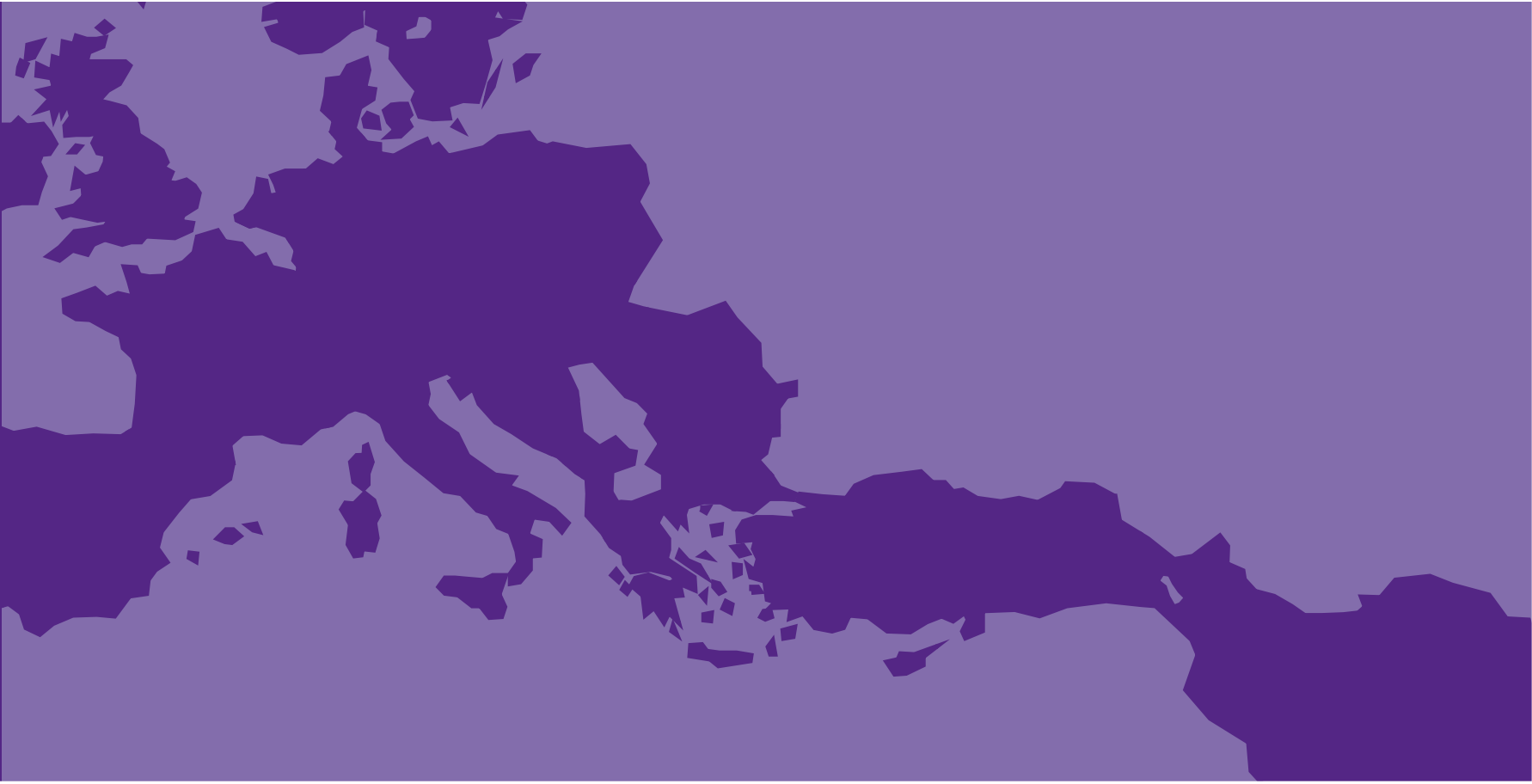

Drug Money: the illicit proceeds of opiates trafficked on the Balkan route 



\section{Drug Money: the illicit proceeds of opiates trafficked on the Balkan route}




\section{UNODC Disclaimers}

In this document, South-Eastern Europe is understood to include the following: Albania, Bosnia and Herzegovina, Croatia, Montenegro, Serbia, the former Yugoslav Republic of Macedonia and Kosovo under United Nations Security Council Resolution 1244.

All references to Kosovo in the present document should be understood in the context of the UN Security Council resolution 1244 (1999). All references to Macedonia in the present draft document should be understood in the context of the UN Security Council resolution 817 par.2.

This document has not been formally edited. The contents do not necessarily reflect the views or policies of UNODC or contributory organizations and neither do they imply any endorsement.

The designations employed and the presentation of material in this document do not imply the expression of any opinion on the part of UNODC concerning the legal status of any country, territory or city or its authorities, or concerning the delimitation of its frontiers or boundaries.

Comments on this study are welcome and can be sent to:

Division for Policy Analysis and Public Affairs

United Nations Office on Drugs and Crime

P.O. Box 500

1400 Vienna

Austria

Tel: (+43) 1260600

Fax: (+43) 1260605827

E-mail:rab@unodc.org

Website: www.unodc.org 


\section{Preface}

This study focuses on a vital aspect of illicit drug trafficking: the huge profits that flow from this trade into the hands of criminals and their networks. South-Eastern Europe, through the so-called Balkan route, is a key pathway for the delivery of opiates from Afghanistan into Western and Central Europe.

The present study estimates that the total monetary value of illicit opiates trafficked along the route is worth an average of $\$ 28$ billion per annum. Such funds are, tragically, greater than the entire GDP of Afghanistan; a finding that highlights the scope of the trafficking that occurs through the Balkan route. But the acknowledgement of the problem, and its scale, is only the first step in defining clear and comprehensive solutions.

The recent UNODC Afghanistan Opium Survey 2015 has shown that cultivation and production of opium in the country has declined. This is indeed welcome news. But if we are to capitalise on this, there is a real need for the Afghan Government and the international community, including every country along the Balkan route, to commit themselves to close cooperation.

UNODC is helping through a number of initiatives that seek to promote partnerships, information sharing and joint operations. These are as essential in the Balkans as they are along the other routes moving opiates out of Afghanistan.

As part of our Inter-Regional Drug Control Approach, one such project is our "networking the networks" initiative, which is building greater connectivity. It offers an opportunity to bring together real-time coordination, and a focus on strategy and operational efforts.

Networking the networks has already brought together agencies including CARICC, JPC and GCC CIC, as well as Europol, INTERPOL, the WCO, ASEANAPOL, the Egmont Group and the OSCE. The container control programme, comanaged by UNODC and the World Customs Organization, as well as the Maritime Crime Programme are adding to these efforts to help States disrupt the trafficking flows. Central to this work is chasing down the illicit funds.

Drug Money: the illicit proceeds of opiates trafficked on the Balkan route is essential for our comprehensive response to opiates trafficked in the Balkans and to appreciate the volume of money laundered annually as a result of this trafficking.

Thanks to this study we now have a clearer understanding of illicit funds. We must use it to sharpen our focus on breaking up the criminal networks, seizing their profits before they are laundered and countering the flow of opiates from Afghanistan in full cooperation with Member States.

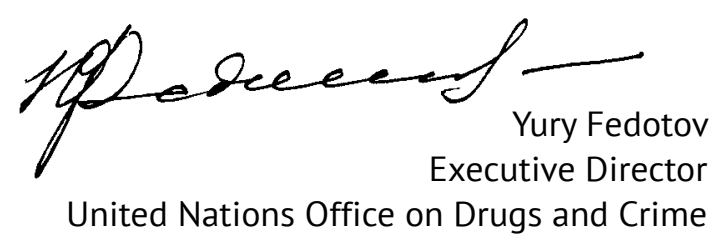




\section{Acknowledgements}

Drug Money: the illicit proceeds of opiates trafficked on the Balkan route was prepared by the Research and Trend Analysis Branch, Division for Policy Analysis and Public Affairs, United Nations Office on Drugs and Crime, in collaboration with the Regional Section for Europe, West and Central Asia, Division for Operations. Supervision was undertaken by JeanLuc Lemahieu, Director of the Division for Policy Analysis and Public Affairs, Angela Me, Chief of the Research and Trend Analysis Branch.

Transcrime, the Joint Research Centre on Transnational Crime of Cattolica and Trento Universities, developed the methodology used in this study and prepared the first draft under the supervision of Prof. Ernesto Ugo Savona.

Within the objectives followed by UNODC's Inter-Regional Drug Control Approach, this study is a joint activity funded and implemented through the UNODC Regional Programme for Afghanistan and Neighbouring Countries and the Regional Programme for South-Eastern Europe.

Core team, Research and Trend Analysis Branch

Chloé Carpentier

Hamid Azizi

Thomas Pietschmann

Irmgard Zeiler

Core team, Regional Section for Europe, West and Central Asia

Alexandre Schmidt

Core team, Transcrime

Alberto Aziani

Valentina Giampietri

Luca Giommoni (Cardiff University)

Editing

Jonathan Gibbons

Coordination

Benjamin Crabtree

Graphic design and layout

Bekbolat Kubeev

Suzanne Kunnen

Kristina Kuttnig

Ilaria Mastro (Transcrime)

Mapping support

Irina Tsoy

The Research and Trend Analysis Branch is grateful for the review of the methodology used in this study by the following experts:

Victoria Greenfield

Michael Osman

Hayley Pisano 


\section{Contents}

Preface $\quad 3$

$\begin{array}{ll}\text { Introduction } & 7\end{array}$

$\begin{array}{lr}\text { Executive summary } & 9\end{array}$

$\begin{array}{ll}\text { The way forward } & 13\end{array}$

1. The Balkan route $\quad 17$

1.1. Source, transit and final destination countries $\quad 18$

$\begin{array}{ll}\text { 1.1.1. Source } & 19\end{array}$

1.1.2. Transit countries $\quad 20$

1.1.3. Final destination countries $\quad 21$

2. The monetary value of illicit opiates trafficked on the Balkan route $\quad 25$

2.1. Estimating the total quantity of illicit Afghan opiates trafficked on the Balkan route 25

2.1.1. Consumption of opiates in the Balkan route countries $\quad 27$

2.1.2. Seizures of opiates in the Balkan route countries $\quad 29$

2.1.3. Total combined quantity of illicit opiates consumed and seized in the Balkan route countries 32

2.1.4. Combined quantity of illicit opiates consumed and seized by sub-region and country 32

2.2. Assessing the flow of illicit opiates on the Balkan route $\quad 35$

2.2.1. Country connections $\quad 36$

2.2.2. Flow of opiates $\quad 36$

2.2.3. Interception rates $\quad 39$

2.3. Estimating the gross profit made from the trafficking of illicit opiates on the Balkan route 40

2.3.1. Breaking gross profit down into its components 40

2.3.2. Gross profit by sub-region and country $\quad 41$

\begin{tabular}{ll} 
3. The monetary value of opiate trafficking relative to GDP & 47 \\
\hline
\end{tabular}

3.1. Total gross profit made from the trafficking of illicit opiates relative to GDP 47

3.2. Total gross profit made from illicit opium trafficking relative to drug-related public expenditure $\quad 49$

Annex 1. Estimating the gross profit made from the trafficking of illicit opiates on the Balkan route $\mathbf{5 5}$

Annex.1.1. The total quantity of opiates trafficked on the Balkan route - Step 1

Annex.1.2. The country network of illicit opiate trafficking on the Balkan route - Step $2 \quad 64$

Annex.1.3. The gross profit of illicit opiate trafficking - Step $3 \quad 72$

Annex 2. Estimating the monetary value of illicit opiate trafficking on the Balkan route 81

\begin{tabular}{lc} 
Annex 3. Estimating purities & 83 \\
\hline
\end{tabular}

Annex 4. Estimating prices $\quad \mathbf{8 5}$

Annex.4.1. International trade prices 86

Annex.4.2. Wholesale prices 87

Annex.4.3. Retail prices 89 


\title{
Abbreviations
}

\author{
EMCDDA European Monitoring Centre for Drugs and Drug Addiction \\ FATF \\ GDP \\ Financial Action Task Force \\ IVTS \\ Gross Domestic Product \\ SELEC \\ Informal Value Transfer Systems \\ UNODC \\ Southeast European Law Enforcement Centre \\ United Nations Office on Drugs and Crime
}




\section{Introduction}

In the context of controlling the supply and demand of illicit drugs, and lessening their burden on the social and economic fabric and stability of United Nations Member States, UNODC has set itself the goal of improving understanding of the economics behind the illicit trafficking of opiates originating in Afghanistan, the source of the vast majority of the world's illicit opiates.

To that end, this study estimates the monetary value (value added) of illicit opiates trafficked on the main conduit for illicit Afghan opiates to Europe, the so-called "Balkan route". Accounting for a significant portion of global consumption of illicit opiates, the Balkan route (through the Islamic Republic of Iran and Turkey via South-Eastern Europe to Western and Central Europe) is one of the most important heroin trafficking routes in the world. For the purposes of this study, the 31 countries (not including Afghanistan) that make up the Balkan route, as well as the territory, Kosovo under United Nations Security Council Resolution 1244, are collectively referred to as the "Balkan route" or the "Balkan route countries".

Using data reported during the 2009-2012 period, this study estimates the monetary value of Afghan opiates trafficked on the Balkan route by estimating the combined quantity of illicit opiates consumed and seized in the Balkan route countries and by assessing the trafficking networks that link them in order to calculate the gross profit made from opiate trafficking at the country level. This study also explores the monetary value of these illicit proceeds in relation to the GDP of the countries involved.

Chapter 1 provides an overview of the Balkan route, in which the Balkan route countries are clustered into three groups according to their geographical position and their role in the trafficking of illicit Afghan opiates.

Chapter 2 estimates the total quantity of opiates trafficked on the Balkan route, defines the trafficking network linking the Balkan route countries and estimates the gross profit made from opiate trafficking at the country level.

Chapter 3 looks at the monetary value of opiates trafficked on the Balkan route in relation to the GDP of the Balkan route countries. 



\section{Executive summary}

The cultivation, production and trafficking of illicit opiates accounted for almost an eighth of the Gross Domestic Product (GDP) of Afghanistan in 2014. Yet the profit made from illicit opiates that actually remains in Afghanistan is only a fraction of the illicit profit made by those who traffic Afghan opiates on the Balkan route.

This study estimates that the total monetary value (value added) of illicit opiates trafficked on the Balkan route amounts to an average of $\$ 28.0$ billion per annum. Even though the Balkan route only accounts for a part of all the opiates trafficked from Afghanistan to markets around the world, this sum is still roughly a third bigger than the entire GDP of the source country ( $\$ 21.2$ billion in 2014). While much attention is focused on the production of illicit opiates in Afghanistan, this shows that, in economic terms, Afghanistan is just one element of a much bigger problem, as the negative economic impact of illicit opiates is actually greater in the Balkan route countries than in Afghanistan itself. The fact that opiates are only one of several types of illicit drug available in the marketplace underlines the magnitude of the economic value of illicit drugs in those countries.

It is not the intention of this study to rank the individual Balkan route countries in terms of the monetary value of the trafficking of illicit opiates. Every country faces different problems and a unique set of circumstances, which are partly a function of the geographical location of each country on the Balkan route and the principal role it plays, be it as a transit or consumer country of illicit opiates.

Retail, international trade and wholesale are the main components that govern the total gross profit made from illicit opiate trafficking. The importance of these components varies according to the role a country plays in international trade, the number of opiate consumers, the intensity of law enforcement counter-measures, and purity-adjusted prices, but analysis of the components of monetary value confirms the centrality of retail sale in the illicit opiate economy.

The large quantity of opiates trafficked across the Islamic Republic of Iran and the country's high domestic consumption of opiates mean that, at $\$ 7.5$ billion and accounting for 27 per cent of the total monetary value of opiates trafficked on the Balkan route, the gross profit made by traffickers of illicit opiates in the Islamic Republic of Iran is the highest of any single country on the Balkan route.

It is, however, the large consumer markets in the countries at the western end of the Balkan route that together account for the largest share of total gross profit made by the traffickers of illicit opiates. Totalling 64.7 per cent of the total gross profit generated on the entire route, a combined annual gross profit of $\$ 18.1$ billion is made by traffickers of illicit opiates in the countries of Western and Central Europe - more than the entire GDP of Bosnia and Herzegovina.

The four largest European markets together account for nearly half of the annual gross profit generated by the trafficking of opiates on the entire Balkan route. This figure is roughly $\$ 5.1$ billion in France, $\$ 3.4$ billion in the United Kingdom, $\$ 2.6$ in Germany and \$1.5 in Italy. High levels of opiate consumption and high purity-adjusted prices at retail explain the magnitude of the illicit gross profit in those countries.

Despite being the second main transit country on the Balkan route, and the large amount of opiates flowing through the country, Turkey has a low prevalence of opiate use. The retail market for opiates in Turkey is therefore relatively small, as is, at $\$ 0.8$ billion, the annual gross profit made by opiate traffickers in the country.

The total gross profit made by opiate traffickers in the countries of South-Eastern Europe amounts to $\$ 1.7$ billion per annum. This value is less than a tenth of the total gross profit made from opiate trafficking on the entire Balkan route. Opiate traffickers in Bulgaria, with a gross profit of $\$ 0.6$ billion, made the highest gross profit in the sub-region.

Another way of looking at the magnitude of the monetary value of illicit opiates trafficked on the Balkan route is to compare it with GDP. This indicator varies considerably across countries according to the role they play in opiate 
trafficking and the size of their economies, but it is equal to 0.15 per cent of the combined GDP of all the Balkan route countries. At first glance not a significant share, yet only slightly less than the percentage of GDP that some of the world's wealthiest countries spend on foreign aid (United States: 0.19 per cent; Spain: 0.16 per cent: OECD 2013).

If the monetary value of illicit opiates trafficked accounts for a sizeable share of a country's GDP, the capital generated may compete with that made from licit economic activities by introducing significant macroeconomic distortions. It is therefore important to determine the relative economic scale of the trafficking of illicit opiates since its potential economic consequences depend not only on the amount of money that opiate trafficking generates, but also on its magnitude with respect to national economies.

Accounting for 1.66 per cent of GDP and corresponding to an annual figure of $\$ 98.4$ per inhabitant, the monetary value of the illicit opiate trade is significant for traffickers in the Islamic Republic of Iran. By contrast, although Turkey also plays a pivotal role in opiate trafficking on the Balkan route, the country has a relatively low opiate consumption rate as well as a GDP (an annual average of $\$ 727$ billion in 2009-2012) far larger than that of the Islamic Republic of Iran, therefore the gross profit made from illicit opiate trafficking in Turkey accounts for less than 0.11 per cent of GDP.

The monetary value of opiate trafficking is considerable in several countries in South-Eastern Europe. Albania (2.60 per cent of GDP) and Bulgaria (1.22 per cent of GDP), in particular, are the two countries with the highest ratio between gross profit and GDP on the Balkan route, which can be explained by the strategic location of those countries in the trafficking of opiates on the route. The monetary value of opiate trafficking is less significant in the largest countries in the sub-region, such as Serbia (0.08 per cent), Romania (0.08 per cent) and Greece (0.08 per cent).

As to be expected, it is in the countries with smaller GDPs on the Balkan route that opiate trafficking has the greatest relative monetary value. This is underlined by the fact that, overall, the monetary value of illicit opium trafficking is 0.11 per cent of the combined GDP of the Western and Central European countries, and while this sub-region is where the largest amount of gross profit is made on the Balkan route, it is where the monetary value of the opiates trafficked is the smallest relative to national economies.

The countries of Western and Central Europe, most of which have sizeable licit economies, are the main destination markets for Afghan opiates trafficked on the Balkan route. Yet the monetary value of those illicit opiates is quite different among the four main European markets. The gross profit made from illicit opiates is relatively high in France (0.19 per cent of GDP) and in the United Kingdom ( 0.14 of GDP), whereas it is 0.07 per cent in Italy and 0.08 per cent in Germany.

The Netherlands and Belgium are among the countries with the lowest ratios of gross profit to GDP on the Balkan route $(0.02$ and 0.03 per cent, respectively), notwithstanding their position as international trade hubs. In countries such as Ireland ( 0.31 per cent of GDP) and Austria ( 0.26 per cent of GDP), the potential spillover from the profit made from illicit opiate trafficking may be significant.

The above figures are the results of a model that calculates the monetary value of opiates trafficked on the Balkan route from the combination of total consumption and seizures of opiates at the national level and the flow of opiates trafficked through each country. Based on this approach, the combined quantity of illicit opiates consumed and seized in the Balkan route countries is estimated to be an annual average of 170.0 tons of pure heroin equivalent. The best estimate of the total annual consumption of illicit opiates is 111.3 tons in pure heroin equivalent, while an annual average of 58.7 tons of illicit opiates was seized in the Balkan route countries in the period 2009-2012. The volume seized corresponds to more than 80 per cent of global seizures of illicit opiates. Overall, 60 per cent of the seizures concerned heroin (including morphine), the rest concerned opium.

Quantities seized and interception rates vary considerably across countries. The Islamic Republic of Iran seizes an annual average of 46.7 tons of illicit opiates in pure heroin equivalent and has the highest interception rate on the Balkan route. The Iranian authorities intercepted an annual average of 30 per cent of all illicit opiates entering their territory in 2009-12, while Turkey also has a high interception rate, with the authorities intercepting 17 per cent 
of opiates entering the country, an annual average of 8.4 tons. All other Balkan route countries seized a combined annual average of 3.6 tons of illicit opiates or 6 per cent of illicit opiates entering those countries.

Far greater shares of opiates are therefore intercepted close to source, presumably because the flow of opiates is greater there than in the countries further along the Balkan route and because international trade and wholesale play a bigger role. The resulting large shipments of opiates lead to bigger seizures and higher interception rates. By contrast, retail dominates in the large consumer markets in the final destination countries at the western end of the Balkan route, meaning that shipments are smaller than in the countries closer to source and so are seizure quantities and interception rates. Traffickers therefore not only make more income in the large consumer markets, they also run a lower risk of arrest than in the countries closer to source, where the greater flow of illicit opiates leads to greater pressure being placed on law enforcement than further along the Balkan route.

In order to assess the flow of opiates trafficked through each country, this study defines a network that consists of countries and connections between them. By combining this network with the total combined consumption and seizures of illicit opiates in each country it is also possible to estimate the quantity of opiates trafficked from one country to another, which is a function of the quantity of illicit opiates that enter and exit previous countries in the chain. Among the 1,056 possible connections between the Balkan route countries, only 98 were actually identified, showing that opiate trafficking is concentrated into just a few specific paths, or chains of countries, on the Balkan route.

Afghanistan is the producer of all the illicit opiates consumed in the countries along the Balkan route. A small quantity of Afghan opiates destined for the Balkan route reaches the Islamic Republic of Iran through Pakistan, but the vast majority of them reach the Islamic Republic of Iran directly from Afghanistan. In 2009-2012, an average of 154.8 tons of illicit opiates in pure heroin equivalent per year crossed the border from Afghanistan to the Islamic Republic of Iran.

Between 42.3 and 59.1 tons of illicit opiates were trafficked annually from the Islamic Republic of Iran to Turkey in 2009-2012. Turkey is also a key transit country on the Balkan route, with shipments reaching hubs such as Bulgaria (10.3 tons), the Netherlands ( 4.4 tons) and Albania (1.4 tons) as well as main consumer markets such as Germany (6.1 tons), France (5.6) and Italy (2.4 tons).

After Turkey, Bulgaria has a pivotal position in the opiate trade, both in terms of the volume of illicit opiates trafficked (an annual average of 11.5 tons of illicit opiates entering the country and 10.1 tons leaving the country) and the number of country connections. Indeed, most countries in South-Eastern Europe export the majority of the illicit opiates that enter them, making the sub-region an important transit point for opiates bound for Western and Central Europe.

Belgium and the Netherlands also act as hubs for the trafficking of illicit opiates, with more than three quarters of the illicit opiates that enter those countries being subsequently trafficked to other countries. In fact, an annual average of 4.7 tons of pure heroin are subsequently trafficked out of the Netherlands, the fourth-largest quantity of opiates trafficked from a country on the Balkan route. However, most Western and Central-European countries consume the majority of the illicit opiates that make it onto their territory, with only very small amounts being subsequently trafficked elsewhere.

The comparison of the gross profit made by the traffickers of illicit opiates with the drug-related public expenditure dedicated to the implementation of drug policies in those and other Balkan route countries offers a different perspective of the magnitude of the monetary value of illicit opiates trafficked on the route. In all the countries for which data are available, these two values are similar, but in some countries (Czech Republic, France, Ireland, Slovakia, Spain and Turkey) gross profit actually exceeds drug-related public expenditure. In other words, drug traffickers make as much money purely from illicit opiates, as many countries spend on addressing the drug problem. 



\section{The way forward}

This study provides six points for discussion on how law enforcement authorities can effectively tackle trafficking on the Balkan route.

Point 1. Illicit opiate trafficking on the Balkan route is opportunity driven. Trafficking is concentrated in a few specific paths among all the possible connections that may convey opiates from Afghanistan to the final destination markets. Traffickers probably perceive these paths to be the least risky and most convenient ways to bring illicit opiates into the final markets. Indeed, criminals may consider all the alternative paths in their decision-making process and opt for those that maximise their expected returns. Several factors may influence this reasoned decision, such as the possibility to corrupt customs officials, connections with local criminal groups, the general level of enforcement, the prices of illicit opiates in the country, etc.

Point 2. In order to increase the interception of opiate traffickers, law enforcement authorities could focus on these specific paths instead of randomly controlling borders. ${ }^{1}$ For instance, they could develop risk assessment models by creating heat maps of the most vulnerable cross-border paths and identify patterns of the means of transport most frequently used to traffic opiates that correspond to the trafficking hotspots on the Balkan route. If law enforcement authorities used models of this kind, they would be able to employ their resources more efficiently and be more effective in disrupting international opiate trafficking. Within this framework, all countries on the Balkan route would need to share their information, thereby enhancing their analytical capacity to detect illicit trafficking.

Point 3. Changes in opportunity structure may also create changes in illicit opiate trafficking, and law enforcement agencies should consider adjusting their strategy accordingly. Globalization, the abolition of border controls within the European Union, and the ease of movement by criminal groups across countries have facilitated the evolution and adaptation of illicit markets. For instance, the analysis in this study shows the shortcomings of the traditional division among producing, consuming and transit countries. This sub-division is becoming increasingly blurred as European countries assume a pivotal role in international trafficking, and countries at the start of the Balkan route have a large share of consumption.

Point 4. In order to detect changes in illicit opiate trafficking, law enforcement authorities may need to monitor drug supply trafficking in near real-time. This requires the collection and prompt analysis of information on prices, purity, seizures, actors, and modi operandi. Regarding seizures, in particular, it would be necessary to collect and report specific data concerning:

- quantities of opiates seized;

- purity;

- coordinates of the seizure (i.e. latitude and longitude);

- number of traffickers arrested during the seizure; and

- origin/transit/destination countries of the opiates seized.

The annual seizure report of UNODC and the Drug Monitoring Platform may represent the prototypes of such a database. All the Balkan route countries would need to collaborate in the creation of this common protocol for seizure data.

Point 5. Reducing opiate trafficking requires reducing the opacity of the financial system, which facilitates the reinvestment of illicit proceeds in the legitimate economy. The still large presence of cash-based economies, tax havens, secrecy jurisdictions, anonymous companies or other legal entities, and the vulnerabilities intrinsic to some specific economic

\footnotetext{
${ }^{1}$ Edward Kleemans, Melvin R. J. Soudijn, and Anton W. Weenink, "Situational Crime Prevention and Cross-Border Crime," in Situational Prevention of Organized Crimes, ed. Ronald V. Clarke and Nick Tilley (Cullompton, Devon: Willan Publishing, 2010); David Weisburd, "Policing Drug Hot Spots: The Jersey City Drug Market Analysis Experiment," Justice Quarterly Justice Quarterly 12, no. 4 (1995): 711-35.

${ }^{2}$ FATF, International Standards on Combating Money Laundering and the Financing of Terrorism \& Proliferation. The FATF Recommendations.
} 
sectors (i.e. real estate, construction, etc.) are the key factors enabling criminal groups to invest their illicit profits in the licit economy. New policies could be aimed primarily at increasing the efforts and risks required by criminal groups for laundering their proceeds by improving the transparency of financial systems. This means that each State would need to:

- comply with the 25 recommendations of the Financial Action Task Force on combating money laundering; ${ }^{2}$

- require confirmation of the beneficial ownership of all banking and security accounts;

- require information about the final human beneficial owner of all corporations and legal entities;

- provide the necessary instruments and training to financial intelligence units so that suspicious transactions can be rapidly identified;

- promote cooperation among international law enforcement agencies; and

- create and develop integrated database systems so that information can be promptly exchanged at the international level.

Point 6. More cooperation among countries is needed. Opiate trafficking and money laundering-related activities are intrinsically transnational. It is consequently not possible to confine their analysis within country borders. Opiate trafficking on the Balkan route works as a system exploiting the vulnerabilities of the countries composing the network. Since the route is a system, governments and law enforcement authorities would need to work together to eliminate the criminal opportunities that facilitate trafficking. Indeed, cooperation among countries in law enforcement counter-actions and data collection is a key factor in the fight against drug trafficking. 




\section{1:The Balkan route}

Afghanistan is the source of the vast majority of the world's illicit opiates ${ }^{3}$ and, although Afghan opium cultivation and production declined in 2015, ${ }^{4}$ that looks likely to continue to be the case. Afghan opiates are trafficked to markets around the globe via a number of established trafficking routes. The so-called "northern route" (through Central Asia) supplies Afghan opiates to the Russian Federation, while the so-called "southern route" (southwards through the Islamic Republic of Iran or Pakistan) is a collection of trafficking routes that facilitate southerly or northerly flows to a number of destinations including Asia and Africa. As the main conduit for Afghan opiates to Europe, the so-called "Balkan route" (through the Islamic Republic of Iran and Turkey via South-Eastern Europe ${ }^{5}$ to Western and Central Europe $)^{6}$ is possibly the most important heroin trafficking route of all. ${ }^{7}$

Figure 1. The main trafficking routes of Afghan opiates

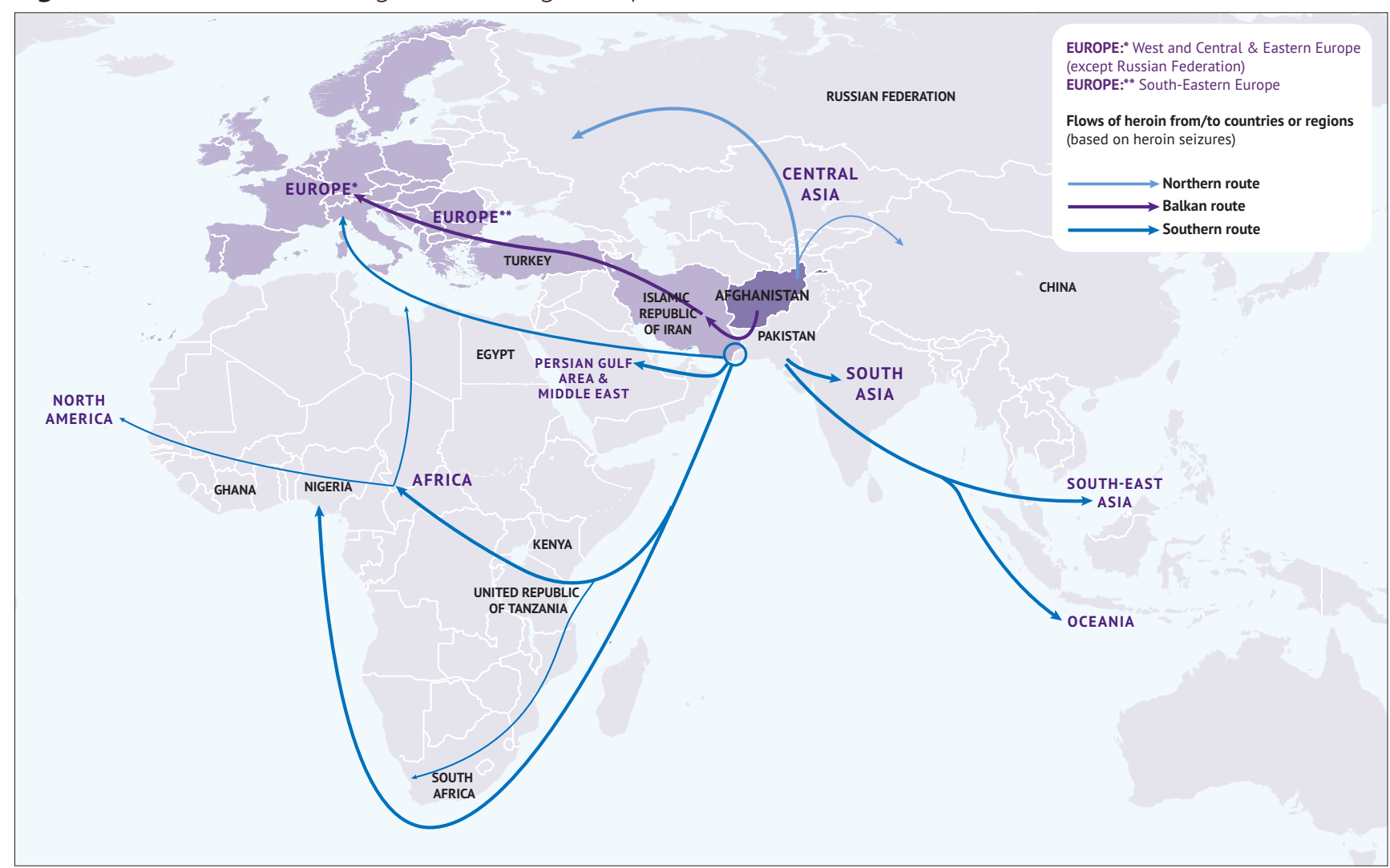

Note: the designations employed and the presentation of material in this map do not imply the expression of any opinion whatsoever on the part of the Secretariat of the United Nations concerning the legal status of any country, territory, city or area or of its authorities, or concerning the delimitation of its frontiers or boundaries. Dashed lines represent undetermined boundaries. The dotted line represents approximately the Line of Control in Jammu and Kashmir agreed upon by India and Pakistan. The final status of Jammu and Kashmir has not yet been agreed upon by the parties. The final boundary between the Sudan and South Sudan has not yet been determined. The trafficking routes represented on the above map should be considered broadly indicative and based on data analysis rather than definitive route outlines. Such analyses are based upon on data related to official drug seizures along the trafficking routes as well as officilal country report and Annual Response Questionnaires. Routes may deviate to other countries along the routes and there are numerous secondary flows that may not be represented.

\footnotetext{
${ }^{3}$ UNODC, World Drug Report 2010 (Vienna, 2010).

${ }^{4}$ UNODC, Afghan Opium Survey 2015 (Vienna, 2010).

${ }^{5}$ South-Eastern Europe is defined as follows: Albania, Bosnia and Herzegovina, Bulgaria, Croatia, Greece, Kosovo, Montenegro, Romania, Serbia and the former Yugoslav Republic of Macedonia.

${ }^{6}$ Western and Central Europe is defined as follows: Austria, Belgium, Czech Republic, Denmark, France, Germany, Hungary, Ireland, Italy, Luxembourg, Norway, Poland, Portugal, Slovakia, Slovenia, Spain, Sweden, Switzerland, the Netherlands and the United Kingdom.

${ }^{7}$ UNODC, The Illicit Drug Trade through South-Eastern Europe (Vienna, 2014).
} 
Figure 2. The Balkan route countries/territory

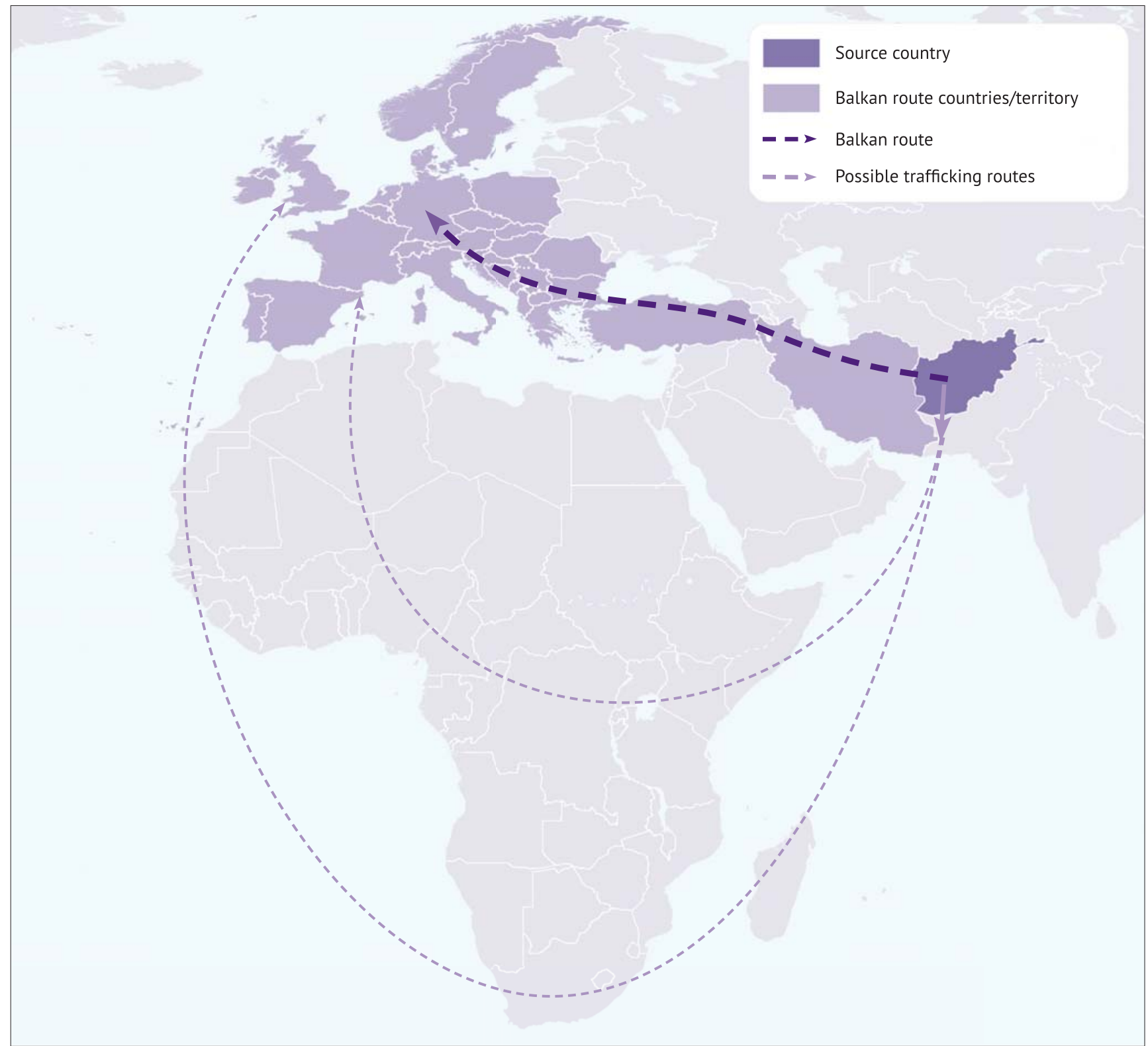

Note: the boundaries and names shown and the designations used on this map do not imply official endorsement or acceplance by the United Nations. The dotted line represents approximately the Line of Control in Jammu and Kashmir agreed upon by India and Pakistan. The final status of Jammu and Kashmir has not yet been agreed upon by the parties.

Source: UNODC.

The Balkan route supplies illicit Afghan opiates to the following 32 countries/territory: Albania; Austria; Belgium; Bosnia and Herzegovina; Bulgaria; Croatia; Czech Republic; Denmark; France; Germany; Greece; Hungary; Iran (Islamic Republic of); Ireland; Italy; Kosovo; Luxembourg; Montenegro; the Netherlands; Norway; Poland; Portugal; Romania; Serbia; Slovakia; Slovenia; Spain; Sweden; Switzerland; Turkey; the United Kingdom of Great Britain and Northern Ireland; and the former Yugoslav Republic of Macedonia. For the purposes of this study they are collectively referred to as "the Balkan route" or "Balkan route countries".

\subsection{Source, transit and final destination countries}

Illicit Afghan opiates in the form of heroin (including morphine) and of small quantities of opium enter the Balkan route by crossing the border with the Islamic Republic of Iran. Small quantities of Afghan opiates also reach the 
Islamic Republic of Iran by passing through Pakistan, ${ }^{8}$ but almost all opiates trafficked through Pakistan end up on the southern route. ${ }^{9}$ The Balkan route then continues to Turkey and reaches the European markets along different paths. ${ }^{10}$

The Balkan route can be divided into three main groups of countries according to their geographical position and principal role in the trafficking of illicit opiates. However, caution should be exercised in regard to this division, as all the Balkan route countries face problems related to the consumption of illicit opiates, which are trafficked from, and to, other Balkan route countries.

\subsubsection{Source}

Opium is cultivated, produced and converted into heroin in Afghanistan before being trafficked on the Balkan route. However, as Afghanistan is not only the source of the illicit opiates trafficked on the Balkan route but also supplies other markets through various other routes, this study treats Afghan figures separately from the estimates of the other Balkan route countries.

\section{Opium production in Afghanistan}

Potential opium production (raw) in Afghanistan was estimated to be 6,400 tons in 2014. Based on seizure data, it was estimated that 62 per cent of that raw opium was converted into heroin within Afghanistan, yielding 210 tons of pure heroin or 410 tons of heroin of export quality (52 per cent purity) and leaving 2,400 tons of opium unprocessed. ${ }^{11}$

Figure 3. Afghanistan: source of all illicit opiates trafficked on the Balkan route

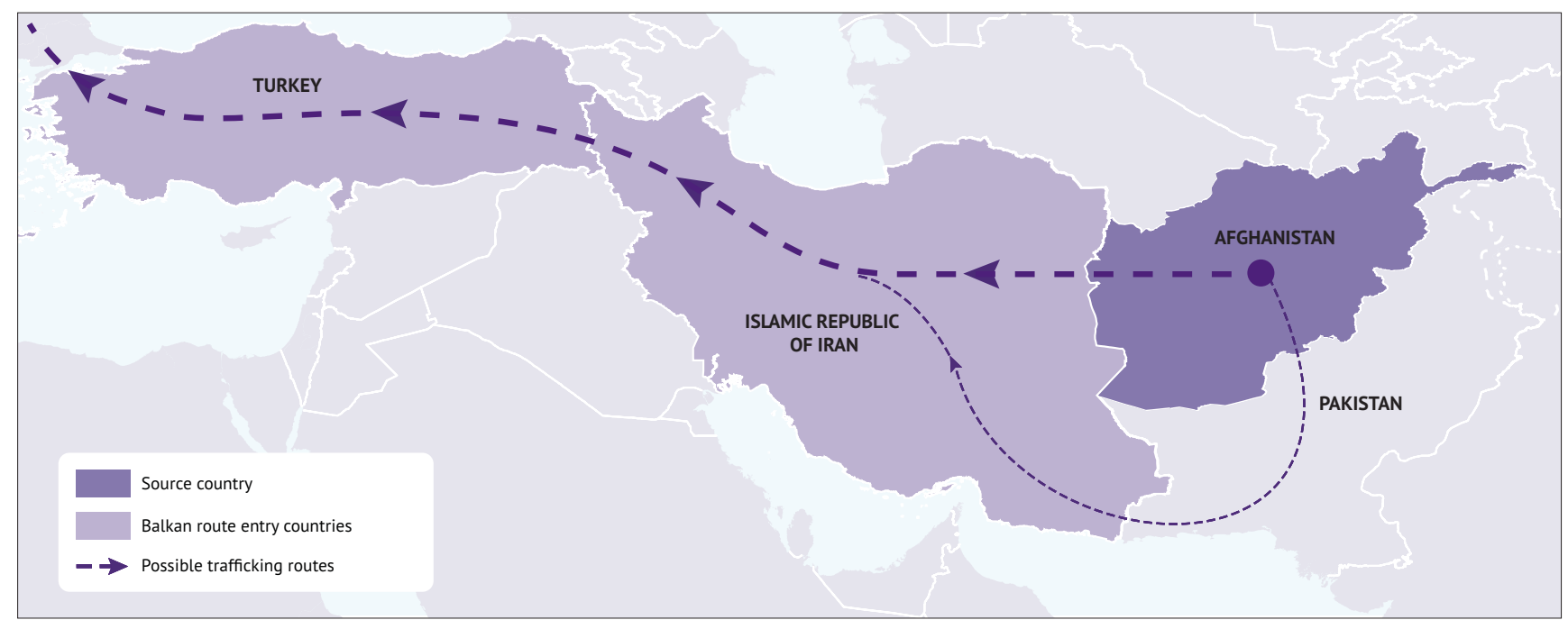

Note: the boundaries and names shown and the designations used on this map do not imply official endorsement or acceplance by the United Nations. The dotted line represents approximately the Line of Control in Jammu and Kashmir agreed upon by India and Pakistan. The final status of Jammu and Kashmir has not yet been agreed upon by the parties.

Source: UNODC.

\footnotetext{
${ }^{8}$ UNODC, The Illicit Drug Trade through South-Eastern Europe (Vienna, 2014).

${ }^{9}$ UNODC, Afghanistan Opiate Trafficking through the Southern Route (Vienna, 2015).

${ }^{10}$ UNODC, World Drug Report 2013 (Vienna, 2013).

${ }^{11}$ UNODC and Islamic Republic of Afghanistan - Ministry of Counter-Narcotics, Afghan Opium Survey 2014 (Vienna, 2014).
} 


\subsubsection{Transit countries}

The Islamic Republic of Iran, Turkey and the other countries of South-Eastern Europe are mainly transit countries for Afghan opiates trafficked on the Balkan route. Turkey serves as a key transit country between the source and the other Balkan route countries, with the vast majority of heroin trafficked through the Islamic Republic of Iran entering Turkey and a large part of it being subsequently trafficked to other European countries. ${ }^{12}$ From Turkey, heroin shipments may:

- depart directly for final destination countries, such as Italy, Germany or France;

- follow the Balkan route overland through Bulgaria and Greece; and

- reach redistribution hubs such as the Netherlands, from where heroin is trafficked to other European countries. ${ }^{13}$

South-Eastern Europe ${ }^{14}$ is strategically situated between the source and the principal destination markets for Afghan opiates in Western and Central Europe. Illicit opiates not only pass through the sub-region but are also repacked there for sale further along the Balkan route. ${ }^{15}$

Figure 4. The three branches of the Balkan route through South-Eastern Europe

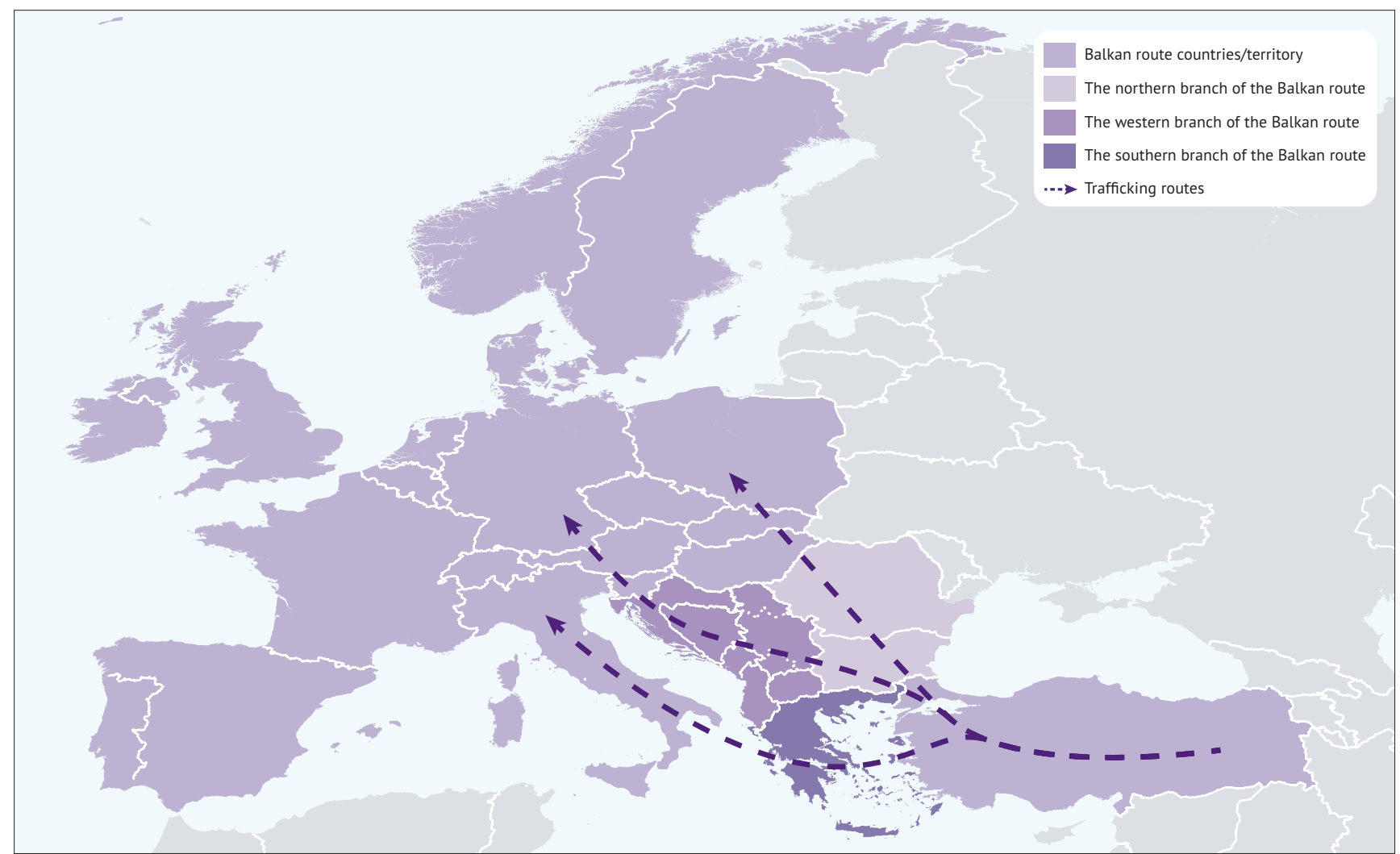

Note: the boundaries and names shown and the designations used on this map do not imply official endorsement or acceptance by the United Nations.

Source: UNODC.

Heroin mostly flows into South-Eastern Europe along three branches of the Balkan route, which start at the Turkish border: ${ }^{16}$

- the northern branch traverses the Eastern Balkans, Bulgaria and Romania, and continues north to Western and Central Europe: ${ }^{17}$

- the southern branch leads directly into the Schengen area of the European Union by crossing the Greek border. Italy is the principal destination of this branch: ${ }^{18}$

\footnotetext{
${ }^{12}$ UNODC, The Global Afghan Opium Trade (Vienna, 2011).

${ }^{13}$ UNODC, The Illicit Drug Trade through South-Eastern Europe, (Vienna, 2014).

${ }^{14}$ Ibid.

${ }^{15} \mathrm{Ibid}$.

${ }^{16}$ Ibid.

${ }^{17}$ Ibid.

${ }^{18}$ Ibid.
} 
- the western branch passes through the western Balkans, i.e. the former Yugoslav Republic of Macedonia, Albania, Montenegro, Kosovo, Serbia, Bosnia and Herzegovina and Croatia, and may involve both sea and land trajectories to reach Europe. ${ }^{19}$

This classification should, however, be treated with caution since trafficking routes may change over time. Traffickers are likely to divert to alternative paths as a result of emerging factors such as an increase in the demand for illicit opiates, law-enforcement counter-actions and border controls. ${ }^{20}$

\subsubsection{Final destination countries}

The third group comprises the large markets in the final destination countries of Western and Central Europe, where Afghan heroin ends its journey. Here the vast majority of overall consumption is concentrated in four main markets: the United Kingdom, Germany, France and Italy. The Balkan route is regularly referenced as the main transit route for the heroin arriving within those countries' borders, although smaller quantities do arrive via other routes. ${ }^{21}$

${ }^{19}$ UNODC, World Drug Report 2010 (Vienna, 2010).

${ }^{20}$ UNODC, Opiate Flows through Northern Afghanistan and Central Asia (Vienna, 2012).

${ }^{21}$ UNODC, The Illicit Drug Trade through South-Eastern Europe (Vienna, 2014). 

2: The monetary value of illicit opiates trafficked on the Balkan route 



\section{2: The monetary value of illicit opiates trafficked on the Balkan route}

The aim of this study is to estimate the monetary value generated (value added) by the trafficking of illicit opiates on the Balkan route in terms of the gross profit made by traffickers. In this context, gross profit includes the turnover from the international trade, national distribution and retail sales of illicit opiates, minus the costs necessary to buy and/or produce them.

The procedure adopted to estimate the monetary value generated on the Balkan route moves through three steps:

- estimating the total quantity of opiates trafficked on the Balkan route.

- assessing the flow of opiates trafficked on the Balkan route.

- combining the quantity of opiates traded on the Balkan route with prices and costs, thereby estimating the gross profit at the country level.

The figures presented in this study are based on 2009-2012 data (annual averages). Quantities of opiates (heroin/ morphine and opium) are expressed in terms of pure heroin equivalents in order to enable comparison of quantities between different countries, different substances and different stages of the supply chain (see Box 1).

\subsection{Estimating the total quantity of illicit Afghan opiates trafficked on the Balkan route}

In order to estimate the total quantity of opiates trafficked on the Balkan route, the total quantity of illicit opiates consumed at the country level has first to be combined with the total quantity of illicit opiates seized in each country. The assumption adopted in this study is that, at all times, the total supply of opiates equals the total quantity of opiates consumed or seized. This means that the quantity of illicit opiates trafficked from Afghanistan on the Balkan route is equal to the sum of the quantities consumed and seized on the entire Balkan route. This approach is called a demand-based approach (see Box 2).

Figure 5. Total quantity of opiates trafficked on the Balkan route

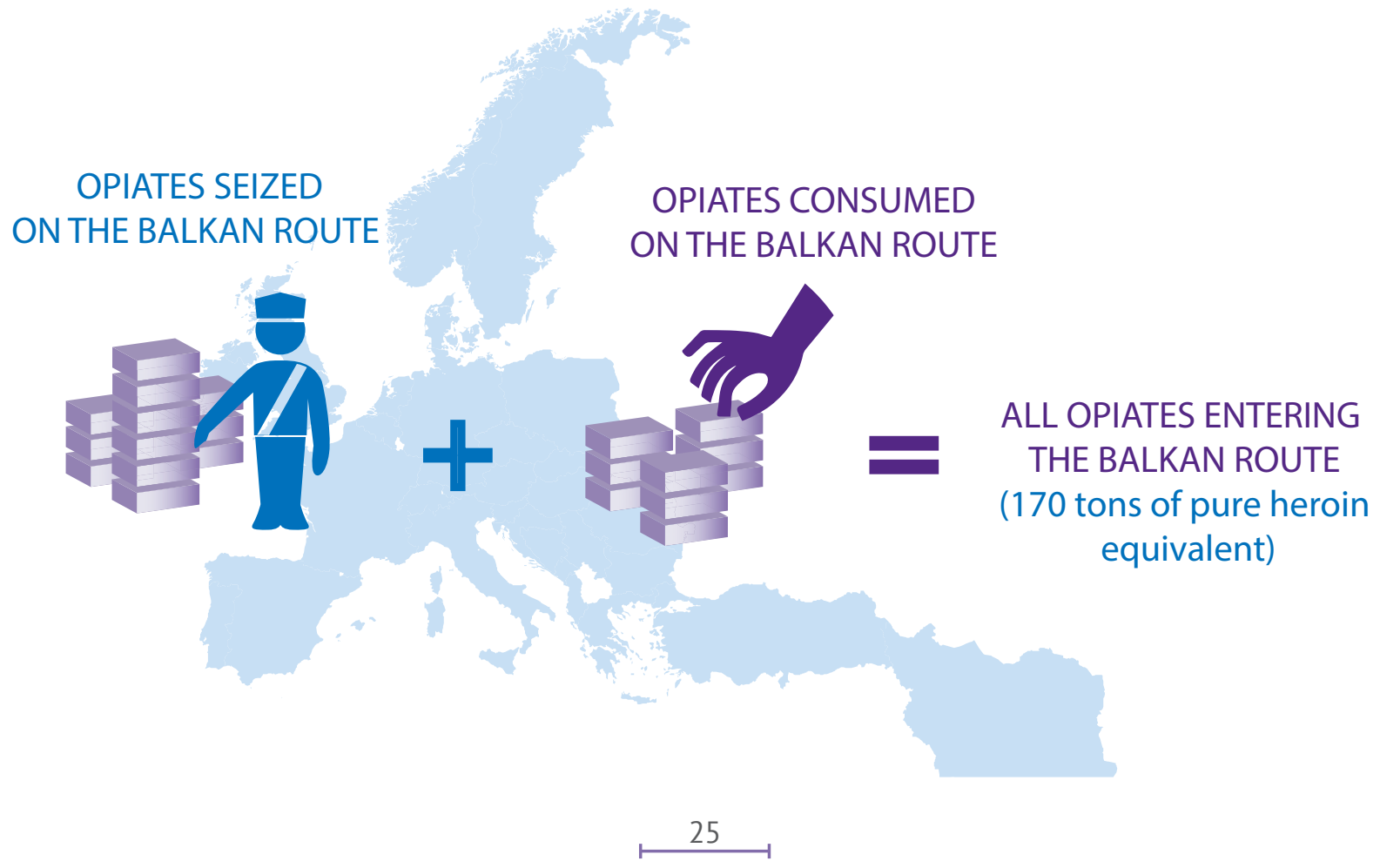




\section{Box 1. Data sources}

With the exception of prevalence data, which are latest reported data, all data presented in this study are the annual averages of data reported during the 2009-2012 period.

\section{Prevalence}

Data on annual prevalence of opiate use among the general population aged 15-64 are provided by the World Drug Report ${ }^{22}$ and supplemented by data provided by EMCDDA ${ }^{23}$ (particularly in the case of Kosovo and Montenegro).

\section{Population data}

Population data on the population aged 15-64 are retrieved from the United Nations Department of Economic and Social Affairs, Population Division (2015).

\section{Number of illicit opiate users}

The number of illicit opiate users is the product of annual prevalence and the size of the population aged 15-64.

\section{Consumption data}

As the best estimate of annual heroin consumption per user, 44.0 pure grams of pure heroin per year is used in this study (low estimate: 35.0; high estimate: 54.0 grams of pure heroin). This value is the average of 29 different estimates of per-user annual consumption. ${ }^{24}$ An annual per-user consumption of 75725 grams of opium is considered in this study.

\section{Retail, wholesale and international trade}

International trade refers to the trade level at which large quantities (more than $10 \mathrm{~kg}$ ) of illicit opiates are trafficked across international borders, and to their distribution to wholesalers in final markets. ${ }^{26}$ Wholesale refers to the handling of large quantities (larger than $1 \mathrm{~kg}$ but smaller than $10 \mathrm{~kg}$ ) of illicit opiates domestically. ${ }^{27}$ Retail refers to the sale of illicit opiates to final consumers. ${ }^{28}$

\section{Seizure data}

Member States report data on amounts of drugs seized to UNODC each year. These data are presented in the World Drug Report. ${ }^{29}$ As seizure data are reported without adjusting for purity, the amounts reported are of unknown purity.

Member States report data on purity independently of amounts seized on two levels (the street level and wholesale level) and provide ideally typical, minimum and maximum purity for each level.

In this study, these two data sets are merged by disaggregating the reported amounts seized into three levels: seizures at the international trade level (highest purity), wholesale level and retail level (lowest purity); and by applying the reported purities by combining minimum, typical and maximum purities accordingly.

\section{Conversion of opium to pure opiate equivalents}

Opium consumption and seizures are converted to units of pure heroin equivalent by applying the conversion factor used in the Afghanistan Opium Survey 2014, which indicated that 18.5 units of opium are needed to produce a single unit of pure heroin base. ${ }^{30}$

\section{Trafficking routes}

The most important data source for establishing the network of trafficking routes are the data on significant individual drug seizures reported to UNODC by Member States: some of the seizure cases recorded by UNODC

${ }^{22}$ UNODC, World Drug Report, various years. Data available at https://data.unodc.org.

${ }^{23}$ EMCDDA, http://www.emcdda.europa.eu/.

${ }^{24}$ Gossop et al. (1997), Uchtenhagen et al. (1997), UNODC (2005), Eisenbach Stangl (2007), EMCDDA (2008), Paoli et al. (2009), Kilmer et al. (2011), Eisenbach Stangl and Rodriguez (2012).

${ }^{25}$ UNODC and Islamic Republic of Afghanistan - Ministry of Counter Narcotics, Afghanistan Opium Survey 2012 (Vienna, 2012).

${ }^{26}$ FATF/OECD, Financial Flows Linked to the Production and Trafficking of Afghan Opiates.

${ }^{27}$ EMCDDA, Pilot Study on Wholesale Drug Prices in Europe (Lisbon, 2011).

${ }^{28}$ FATF/OECD, Financial Flows Linked to the Production and Trafficking of Afghan Opiates; Executive Office of the President Office of National Drug Control Policy, “Technical Report for The Price and Purity of Illicit Drugs: 1981 Through the Second Quarter of 2003” (Washington D.C, November 2004), https://www.ncjrs.gov/ondcppubs/publications/pdf/price_purity_tech_rpt.pdf.

${ }^{29}$ UNODC, World Drug Report, various years. Data available at https://data.unodc.org.

${ }^{30}$ UNODC and Islamic Republic of Afghanistan Ministry of Counter-Narcotics, Afghan Opium Survey 2014 (Vienna, 2014). 
report information on the producing or manufacturing country, departure or obtained country, and destination country, which is used for establishing a connection between countries. These data are supplemented by data on trafficking routes reported to UNODC through the Annual Report Questionnaires, which form the backbone of the World Drug Report.

\section{Price data}

Prices are reported to UNODC by Member States at six different levels (minimum, typical and maximum price at the street and the wholesale levels); however, this data set is far from complete. This study uses a variety of methods to estimate missing data. Once data are imputed a similar scheme is applied to map the data sets to the three trade levels considered, as used for purities.

\subsubsection{Consumption of opiates in the Balkan route countries}

This study calculates the quantity of illicit opiates consumed at the national level by multiplying the national number of opiate users ${ }^{31}$ by per-user annual consumption of opiates.

A critical component is the annual amount of illicit opiates consumed per user. As the best estimate, this study uses an annual heroin consumption of 44.0 pure grams of heroin per year. This value is the average of 29 different estimates of per-user annual consumption. ${ }^{32}$ The low and the high estimate are annual consumptions of 35.0 and 54.0 grams of pure heroin per user. For unrefined opiate products, this study considers an annual per-user consumption of 757 grams of opium. ${ }^{33}$

\section{Box 2. Demand-side estimates}

There are two methods for estimating the quantity of drugs available in a market: the supply-side approach and demand-side approach.

- Supply-based approaches take production at source as a starting point, then quantify drugs available in the market by considering production per hectare, eradication, yields, import/export, etc. ${ }^{34}$ These $^{2}$ quantities are then mapped to trafficking routes by using, for example, seizure data to estimate the amounts trafficked to a specific country or region.

- Demand-based approaches take the destination countries as a starting point (in contrast to source countries) and are based on total quantities consumed, among other things, on an estimation of the number of drug users and on their annual consumption of drugs. ${ }^{35}$

This study adopts a demand-side approach, which is well established in scientific literature. ${ }^{36}$ Although demandbased approaches are considered more stable than supply-based approaches, they suffer from several limitations related to the estimation of both prevalence and per-user consumption. ${ }^{37}$

One limitation is the lack of good estimates of the quantities of drugs consumed by opiate users. This may profoundly affect the quality of the estimates and of the analysis of drug markets. The difficulties of developing consumption estimates are related to the fact that users cannot report precisely how much of an illegal drug

\footnotetext{
${ }^{31}$ The number of illicit opiate users in a country is the product of the most recent available data on prevalence of opiate use and the national adult population in the same year.

${ }^{32}$ Gossop et al. (1997), Uchtenhagen et al. (1997), UNODC (2005), Eisenbach Stangl (2007), EMCDDA (2008), Paoli et al. (2009), Kilmer et al. (2011), Eisenbach Stangl and Rodriguez (2012) collect all these studies.

${ }^{33}$ UNODC and Islamic Republic of Afghanistan - Ministry of Counter Narcotics, Afghanistan Opium Survey 2009 (Vienna, 2009), http://www. unodc.org/documents/crop-monitoring/Afghanistan/Afghan_report_Summary__Findings_2013.pdf.

${ }^{34}$ UNODC and Islamic Republic of Afghanistan Ministry of Counter-Narcotics, Afghan Opium Survey 2014 (Vienna: United Nation Office on Drugs and Crime, 2014), http://www.unodc.org/documents/crop-monitoring/Afghanistan/Afghan-opium-survey-2014.pdf.

${ }^{35}$ Beau Kilmer et al., "Bringing Perspective to Illicit Markets: Estimating the Size of the U.S. Marijuana Market," Drug and Alcohol Dependence 119, no. 1-2 (2011): 153-60.

${ }^{36} \mathrm{Ibid}$.

${ }^{37}$ Matthew Hickman and C. Taylor, "Estimating the Prevalence of Problematic Drug Use: A Review of Methods and Their Application," Offprint from Bulletin on Narcotics LIV, no. 1 and 2 (2002).
} 
they purchase; nor can they state its quality. Consequently, not enough data are available to permit countryspecific estimates of the average consumption for most of the countries included in this study. An average is applied to all countries.

A second limitation pertains to the availability of purity of seizure data. To get a precise idea of the quantities of opiates trafficked, seizures have to be considered in pure quality. However, only a limited number of Member States report purity data, therefore a number of assumptions have had to be made to convert reported seizures into pure equivalents.

Table 1. Estimated heroin and opium consumption in the Balkan route countries/territory (kilograms of pure illicit opiates), 2009-2012 average

\begin{tabular}{|c|c|c|c|c|c|}
\hline & \multirow{2}{*}{$\begin{array}{c}\text { Annual } \\
\text { Prevalence }\end{array}$} & \multicolumn{3}{|c|}{ Heroin consumption (kilograms) } & \multirow{2}{*}{$\begin{array}{l}\text { Opium consumption } \\
\text { (kilograms of pure heroin } \\
\text { equivalent) }\end{array}$} \\
\hline & & $\begin{array}{c}\text { Low } \\
\text { estimate }\end{array}$ & $\begin{array}{c}\text { Best } \\
\text { estimate }\end{array}$ & $\begin{array}{c}\text { High } \\
\text { estimate }\end{array}$ & \\
\hline $\begin{array}{l}\text { Albania } \\
\text { Austria }\end{array}$ & $0.45 \%$ & 331 & 416 & 511 & - \\
\hline \multirow{4}{*}{$\begin{array}{l}\text { Austria } \\
\text { Belgium } \\
\text { Bosnia and Herzegovina } \\
\text { Bulgaria }\end{array}$} & $0.45 \%$ & 897 & 1,128 & 1,384 & - \\
\hline & $0.20 \%$ & 495 & 623 & 764 & - \\
\hline & $0.30 \%$ & 285 & 358 & 439 & - \\
\hline & $0.51 \%$ & 893 & 1,122 & 1,377 & - \\
\hline \multirow{2}{*}{$\begin{array}{l}\text { Croatia } \\
\text { Czech Republic }\end{array}$} & $0.36 \%$ & 362 & 455 & 559 & - \\
\hline & $0.15 \%$ & 379 & 477 & 585 & - \\
\hline Denmark & $0.52 \%$ & 661 & 830 & 1,019 & - \\
\hline \multirow{2}{*}{$\begin{array}{l}\text { France } \\
\text { Germany }\end{array}$} & $0.49 \%$ & 7,204 & 9,056 & 11,114 & - \\
\hline & $0.40 \%$ & 7,589 & 9,540 & 11,708 & - \\
\hline Greece & $0.29 \%$ & 737 & 926 & 1,137 & - \\
\hline \multirow{3}{*}{$\begin{array}{l}\text { Hungary } \\
\text { Iran (Islamic Republic of) } \\
\text { Ireland }\end{array}$} & $0.05 \%$ & 120 & 150 & 185 & - \\
\hline & $2.27 \%$ & 25,703 & 32,313 & 39,656 & 19,215 \\
\hline & $0.72 \%$ & 740 & 931 & 1,142 & - \\
\hline Italy & $0.45 \%$ & 6,095 & 7,662 & 9,404 & - \\
\hline \multirow{2}{*}{$\begin{array}{l}\text { Kosovo } \\
\text { Luxembourg }\end{array}$} & $0.40 \%$ & 164 & 206 & 253 & - \\
\hline & $0.59 \%$ & 67 & 84 & 104 & - \\
\hline $\begin{array}{l}\text { Luxembourg } \\
\text { fYR of Macedonia }\end{array}$ & $0.50 \%$ & 255 & 321 & 394 & - \\
\hline Montenegro & $0.36 \%$ & 53 & 66 & 82 & - \\
\hline \multirow{2}{*}{$\begin{array}{l}\text { Netherlands } \\
\text { Norway }\end{array}$} & $0.13 \%$ & 505 & 635 & 779 & - \\
\hline & $0.30 \%$ & 332 & 417 & 512 & - \\
\hline Poland & $0.10 \%$ & 956 & 1,202 & 1,475 & - \\
\hline Portugal & $0.29 \%$ & 704 & 885 & 1,086 & - \\
\hline Romania & $0.11 \%$ & 532 & 669 & 821 & - \\
\hline Serbia & $0.28 \%$ & 485 & 609 & 748 & - \\
\hline \multirow{2}{*}{$\begin{array}{l}\text { Slovakia } \\
\text { Slovenia }\end{array}$} & $0.13 \%$ & 176 & 222 & 272 & - \\
\hline & $0.44 \%$ & 218 & 275 & 337 & - \\
\hline $\begin{array}{l}\text { Slovenia } \\
\text { Spain }\end{array}$ & $0.23 \%$ & 2,510 & 3,155 & 3,873 & - \\
\hline Sweden & $0.23 \%$ & 492 & 618 & 758 & - \\
\hline $\begin{array}{l}\text { Switzerland } \\
\text { Turkey }\end{array}$ & $0.53 \%$ & 1,013 & 1,273 & 1,563 & - \\
\hline \multirow{2}{*}{$\begin{array}{l}\text { Turkey } \\
\text { United Kingdom }\end{array}$} & $0.03 \%$ & 524 & 659 & 809 & - \\
\hline & $0.81 \%$ & 11,802 & 14,837 & 18,209 & - \\
\hline \multicolumn{2}{|l|}{ Balkan route } & 73,278 & 92,121 & 113,057 & 19,215 \\
\hline
\end{tabular}

Note: different assumptions on per-user annual consumption of illicit opiates determine the three estimates..$^{38}$ The quantity consumed is given by the number of users multiplied by the per-user annual consumption.

Source: elaboration on UNODC and EMCDDA data.

${ }^{38}$ Ibid; UNODC and Islamic Republic of Afghanistan - Ministry of Counter Narcotics, Afghanistan Opium Survey 2010, 2011,2012 (Vienna:, 2010, 2011, 2012). 


\subsubsection{Seizures of opiates in the Balkan route countries}

This study estimates purity-adjusted seizures for every Balkan route country in order to compare them across countries and to add them to the quantities of opiates consumed. The latter are expressed in terms of pure substance, although purity of heroin can differ substantially according to the stage of the supply chain that it has reached. For example, purity tends to decrease the closer heroin gets to the final user. ${ }^{39}$ In order to compare seizures of illicit opiates across countries accurately and to compare them to estimated quantities consumed, data on seizures of unknown purity have to be expressed in terms of pure substance; in this case, as pure heroin equivalents. For that purpose, this study considers the weight of morphine equal to the weight of heroin. Opium seizures are converted into pure heroin equivalent by using the conversion factor used in the Afghanistan Opium Survey 2014.40

To adjust for purity, seizures are considered at the retail, wholesale and international trade levels, corresponding to the quantity in which they are traded. Retail level corresponds to seizures below 1 kilogram, wholesale between 1 kilogram and 10 kilograms and international trade above 10 kilograms. Purity is highest at the international trade level and lowest at the retail level, bearing in mind that cutting occurs close to user markets.

\section{Box 3. Estimating purities}

Purity levels are fundamental for estimating the size of opiate markets and for understanding how they work. Despite the centrality of such data, information on the purity of seizures is not available for most countries. ${ }^{41}$ Users, who are able to report how much they spend or how frequently they inject, smoke or inhale, are usually unware of the purity of the substances they buy. ${ }^{42}$ Retail purity levels vary enormously in certain markets.

A comprehensive series of data on heroin purity is available to UNODC. ${ }^{43}$ However, data are incomplete or incoherent for some countries ${ }^{44}$ or for some years. Given the need to perform cross-country analyses based on multiple years (2009-2012 averages), the present study imputes missing data according to the interpolation criteria outlined below). ${ }^{45}$

The imputation process yields a simple average of the purity data for all the Balkan route countries for 20092012. These values are the bases for the estimates of purity-adjusted prices and seizures.

\footnotetext{
${ }^{39}$ Jonathan Caulkins, "Price and Purity Analysis for Illicit Drug: Data and Conceptual Issues," Heinz Research, May 24, 2005, http:/ /repository. cmu.edu/heinzworks/25.

${ }^{40}$ UNODC and Islamic Republic of Afghanistan Ministry of Counter-Narcotics, Afghan Opium Survey 2014 (Vienna, 2014).

${ }^{41}$ Kilmer and Pacula, "Estimating the Size of the Illegal Drug Market: A Demand-Side Approach"; UNODC, The Global Afghan Opium Trade

(Vienna, 2011).

${ }^{42}$ Paoli, Greenfield, and Reuter, The World Heroin Market, 95.

${ }^{43}$ UNODC, "Drug Situation Analysis Report - Islamic Republic of Iran” (Vienna, 2011), https://www.paris-pact.net/upload/8adad0c19394d 428589a714af3f14cad.pdf; UNODC, "Delta Annual Reports Questionnaire Database," 2014.

${ }^{44}$ Whenever the reported or imputed purity levels at the street level are higher than those at the wholesale level, the data are inverted.

$45 \mathrm{i}$ indicates the country considered; $\mathrm{j}$ indicates a country linked to $\mathrm{i}$ through the import or export of illicit opiates.
} 
Table 2. Annual seizures of opiates in the Balkan route countries/territory (converted to kilograms of pure heroin equivalent), 2009-2012 average

\begin{tabular}{|c|c|c|c|c|c|}
\hline & \multicolumn{3}{|c|}{ Heroin } & \multirow{2}{*}{$\begin{array}{c}\text { Opium in pure } \\
\text { heroin equivalent }\end{array}$} & \multirow{2}{*}{ Total } \\
\hline & Retail & Wholesale & International trade & & \\
\hline Albania & 0.01 & 0.08 & 24.28 & - & 24.37 \\
\hline Austria & 0.19 & 2.89 & 46.33 & 11.03 & 60.45 \\
\hline Belgium & 0.37 & 3.10 & 126.94 & 0.33 & 130.74 \\
\hline Bosnia and Herzegovina & 0.04 & 0.23 & 7.48 & - & 7.75 \\
\hline Bulgaria & 0.16 & 1.75 & 261.25 & 0.42 & 263.57 \\
\hline Croatia & 0.12 & 0.81 & 17.96 & - & 18.89 \\
\hline Czech Republic & 0.06 & 0.43 & 7.57 & - & 8.06 \\
\hline Denmark & 0.16 & 1.40 & 18.21 & 0.08 & 19.85 \\
\hline France & 2.07 & 20.47 & 294.46 & 0.34 & 317.34 \\
\hline Germany & 1.91 & 18.79 & 247.23 & 4.12 & 272.04 \\
\hline Greece & 1.34 & 16.90 & 235.69 & 0.21 & 254.14 \\
\hline Hungary & 0.12 & 0.60 & 19.11 & 0.41 & 20.25 \\
\hline Iran (Islamic Republic of) & 30.20 & 313.49 & $22,879.65$ & $23,524.00$ & $46,747.34$ \\
\hline Ireland & 0.39 & 2.32 & 24.76 & - & 27.47 \\
\hline Italy & 5.08 & 28.04 & 451.27 & 0.39 & 484.77 \\
\hline Kosovo & 0.13 & 0.82 & 24.37 & - & 25.32 \\
\hline Luxembourg & 0.01 & 0.06 & 7.37 & - & 7.44 \\
\hline fYR of Macedonia & 0.08 & 0.60 & 39.00 & - & 39.68 \\
\hline Montenegro & 0.00 & 0.02 & 4.26 & - & 4.28 \\
\hline Netherlands & 0.70 & 3.27 & 340.42 & 20.79 & 365.18 \\
\hline Norway & 0.28 & 3.43 & 35.91 & 0.03 & 39.64 \\
\hline Poland & 0.01 & 0.06 & 10.38 & 2.97 & 13.43 \\
\hline Portugal & 0.48 & 3.00 & 32.33 & 0.00 & 35.81 \\
\hline Romania & 0.63 & 3.26 & 23.37 & 0.18 & 27.45 \\
\hline Serbia & 0.15 & 0.83 & 7.60 & - & 8.58 \\
\hline Slovakia & 0.01 & 0.15 & 1.67 & - & 1.83 \\
\hline Slovenia & 0.02 & 0.11 & 8.78 & 0.02 & 8.92 \\
\hline Spain & 2.15 & 12.03 & 162.71 & 0.05 & 176.94 \\
\hline Sweden & 0.20 & 1.46 & 17.29 & 1.66 & 20.61 \\
\hline Switzerland & 0.82 & 5.71 & 87.38 & 0.19 & 94.10 \\
\hline Turkey & 1.45 & 6.92 & $8,361.77$ & 31.21 & $8,401.35$ \\
\hline United Kingdom & 9.12 & 55.41 & 722.84 & - & 787.37 \\
\hline Balkan route & 58.47 & 508.42 & $34,549.64$ & $23,598.43$ & $58,714.95$ \\
\hline
\end{tabular}

Source: Elaboration on UNODC and Rossi and Ricci data. 
Figure 6.1. Heroin seizures in the Balkan route countries/territory (tons of heroin; not purity adjusted), 2000-2012

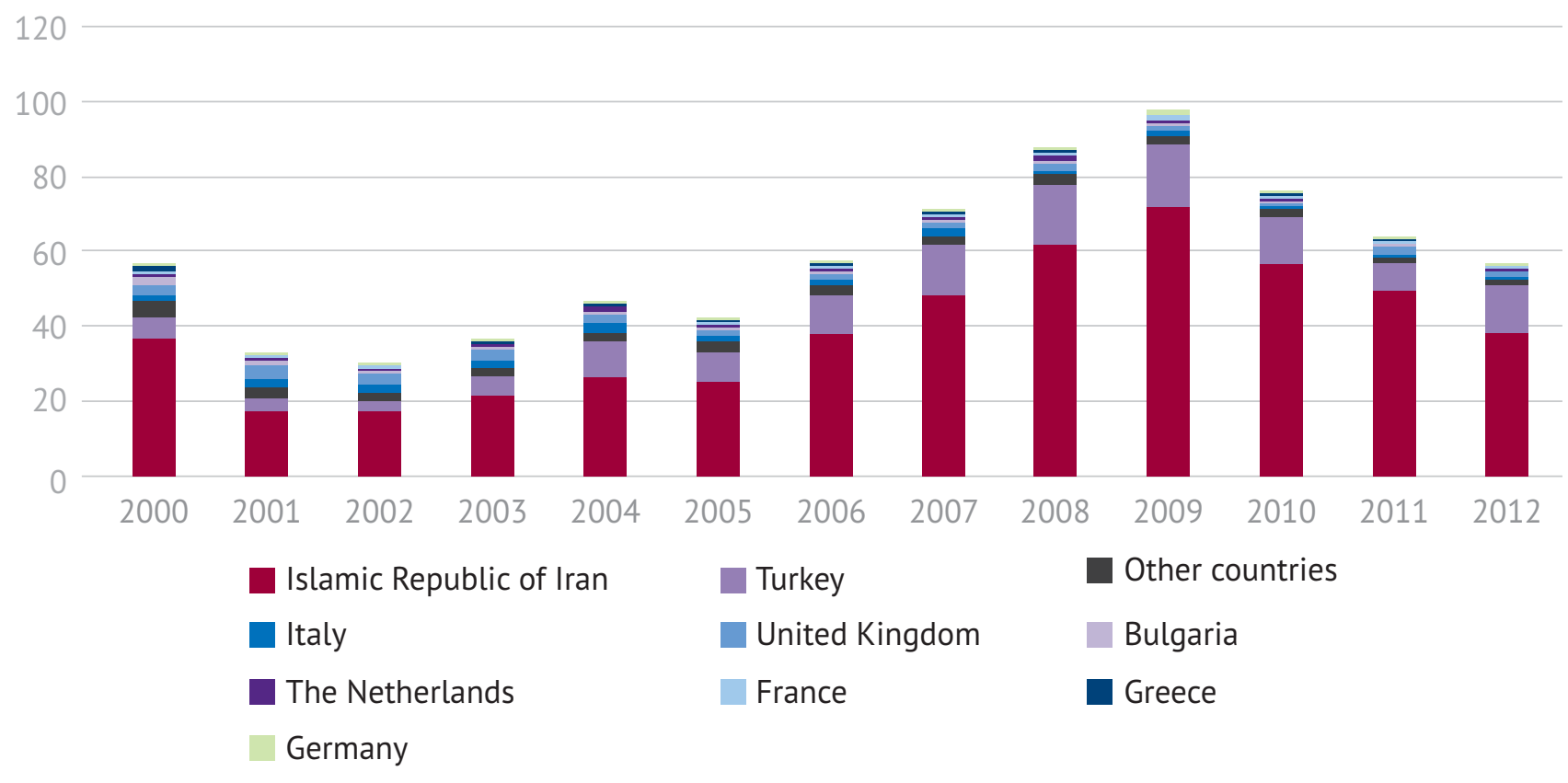

Figure 6.2. Focus on heroin seizures in the European Balkan route countries/territory (tons of heroin; not purity adjusted), 2000-2012

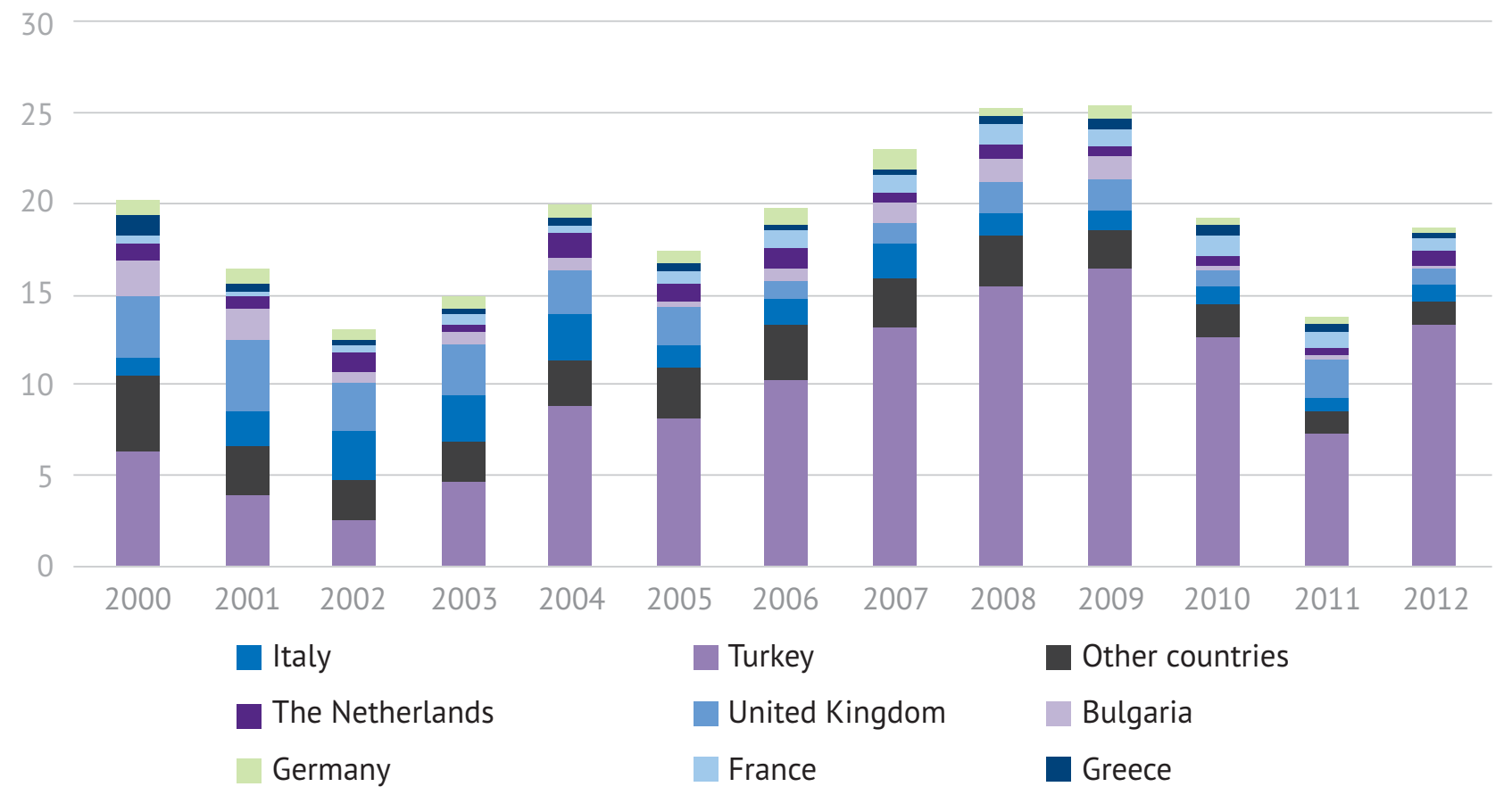

Note: "Other countries/territory" are Albania, Austria, Belgium, Bosnia and Herzegovina, Croatia, Czech Republic, Denmark, Hungary, Ireland, Kosovo, Luxembourg, Montenegro, Norway, Poland, Portugal, Romania, Serbia, Slovakia, Slovenia, Spain, Sweden, Switzerland and the former Yugoslav Republic of Macedonia.

Source: based on UNODC data. 


\subsubsection{Total combined quantity of illicit opiates consumed and seized in the Balkan route countries}

Based on the above approach, the combined quantity of illicit opiates consumed (consumption) and seized in the Balkan route countries amounts to 170.0 tons of pure heroin equivalent per annum (range:151.2-191.0 tons). The best estimate of average annual total consumption of illicit opiates is 111.3 tons in pure heroin equivalent (range: 92.4132.3 tons). ${ }^{46}$ All the Balkan route countries register heroin consumption while opium consumption is concentrated almost exclusively in the Islamic Republic of Iran.

An annual average of 58.7 tons of illicit opiates was seized in the Balkan route countries in 2009-2012, which corresponds to more than 80 per cent of global seizures of illicit opiates. Overall, 60 per cent of the seizures concerned heroin (including morphine), the rest concerned opium.

Seizures do, however, vary considerably across countries. The Islamic Republic of Iran alone seized 46.7 tons of illicit opiates in pure heroin equivalent (30 per cent of illicit opiates entering the country), Turkey intercepted an average of 8.4 tons per annum (17 per cent of opiates entering the country), while all other Balkan route countries seized a combined annual average of 3.6 tons of illicit opiates ( 6 per cent of illicit opiates entering those countries). Thus, far greater quantities of opiates are seized closer to source, presumably because bigger shipments of opiates are trafficked through those countries than in the countries further along the Balkan route.

\subsubsection{Combined quantity of illicit opiates consumed and seized by sub-region and country}

Estimates indicate that the Islamic Republic of Iran consumes more than a quarter of the pure heroin trafficked via the Balkan route (range: 25.7-39.6 tons) and almost all the opium (19.2 tons), in addition to carrying out more than two-thirds of total seizures of heroin and morphine (23.2 tons of pure heroin equivalent) and more than 90 per cent of opium seizures ( 23.5 tons of pure heroin equivalent). The combined quantity of illicit opiates consumed and seized annually in the Islamic Republic of Iran is therefore estimated at 98.3 tons (range: 91.7-105.6 tons).

Far smaller, the combined quantity of illicit opiates consumed and seized annually in Turkey is estimated at 9.1 tons (range: 8.9-9.2 tons). At between 0.5 and 0.8 tons of pure heroin equivalent, consumption of illicit opiates is low considering the size of the country's population (74 million in 2012), but the fact that Turkey seized the second largest annual average quantity of opiates (8.4 tons) trafficked on the Balkan route highlights the importance of Turkey as a transit country to the large European consumer markets.

The combined quantity of illicit opiates consumed and seized annually in South-Eastern Europe is estimated at 6.6 tons (range: 5.0-7.3 tons). At between 4.1 and 6.3 tons of illicit opiates (see Figure 8), annual consumption represents 8.5 per cent of the consumption of opiates trafficked on the Balkan route. With an annual average consumption of 1.1 tons of pure heroin, Bulgaria is apparently the largest domestic market for illicit opiates in South-Eastern Europe, followed by Greece ( 0.9 tons) and Romania ( 0.7 tons). Total seizures in South-Eastern Europe are relatively small with the entire sub-region seizing 0.7 tons of illicit opiates per year, which is equivalent to 8 per cent of the seizures carried out by Turkey alone. Greece (254 kilograms) and Bulgaria (264 kilograms) together seize more than 70 per cent of the sub-region's total.

\footnotetext{
${ }^{46}$ Consumption indicates the quantity of illicit opiates that drug users actually buy. The estimate of the national consumption relies on data on prevalence and per-user consumption (see Annex). Caution is necessary when making cross-country comparisons on the quantity of opiates consumed. Opiate consumption is based on the opiate prevalence reported by countries, and it may, in part, reflect the different data collection process employed by each country. Quantities of opiates (heroin/morphine and opium) are expressed in terms of kilograms of pure heroin equivalents to enable comparison of volumes among countries, different substances, and different levels of the supply chain.
} 
Figure 7. Seizures of illicit opiates in the Balkan route countries/territory (kilograms of pure heroin equivalent), 2009-2012 average

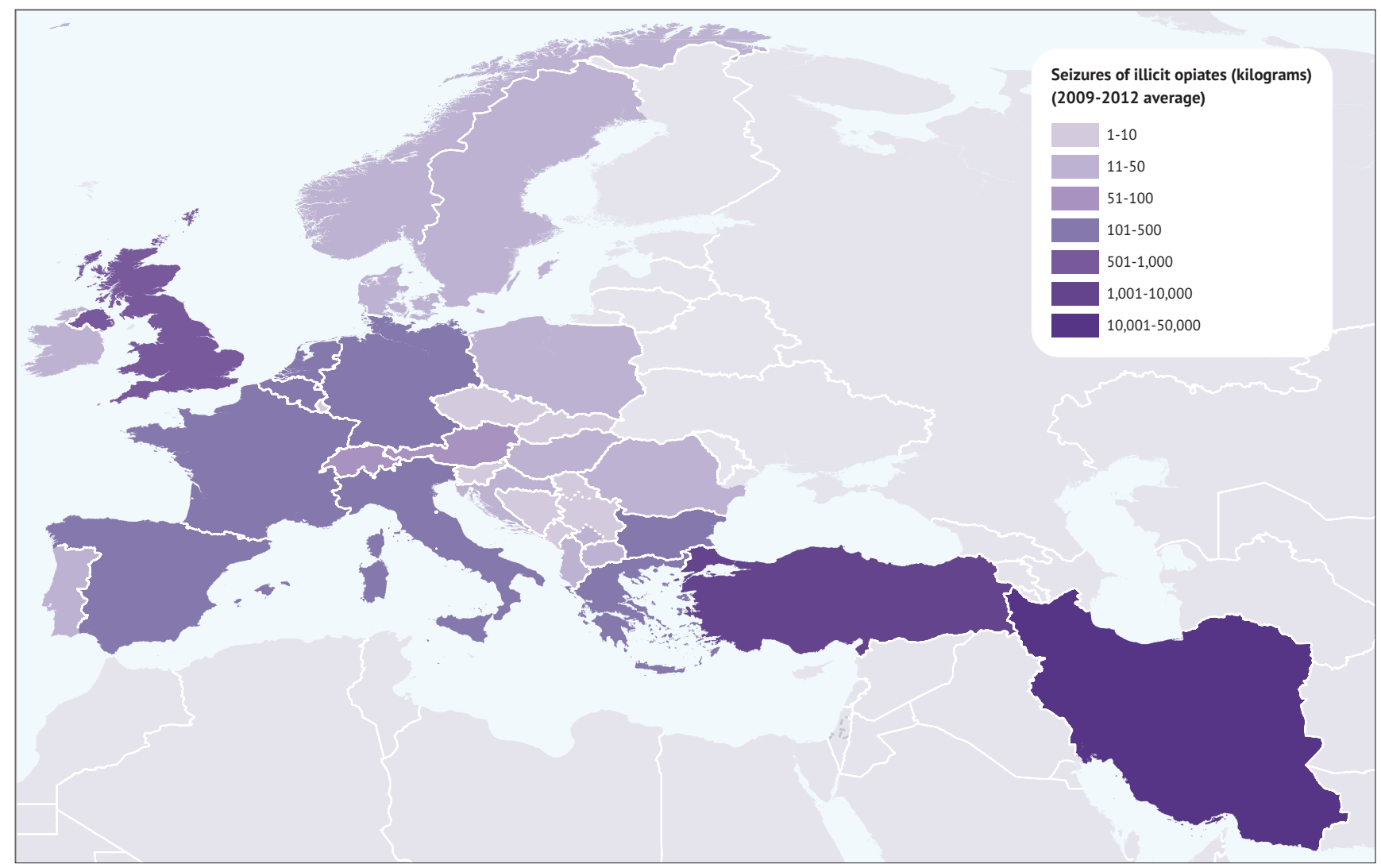

Note: the boundaries and names shown and the designations used on this map do not imply official endorsement or acceptance by the United Nations. The map represents the best estimate.

Source: based on UNODC data.

The countries of Western and Central Europe consume 53.7 tons (range: 42.7-65.9 tons) of pure heroin per year. More than 75 per cent of consumption is concentrated in the four largest consumer markets (see Figure 8). The United Kingdom, Germany, France and Italy together consume 41.1 of those 53.7 tons but, with an annual consumption ranging between 11.8 and 18.2 tons, the United Kingdom is by far the largest European market.

On average, annual seizures in the period 2009-2012 amounted to 2.8 tons in Western and Central Europe. The largest European consumer markets in the sub-region tend to be the countries that intercept the largest amounts of illicit opiates. The United Kingdom and Italy, in particular, respectively seize an average of 0.8 and 0.5 tons of pure heroin equivalent per year. However, the Netherlands is among the principal countries by volume seized (around 0.4 tons per year) despite its relatively low consumption ( 0.6 tons of pure heroin equivalent per year). 
Figure 8. Illicit opiate consumption in the Balkan route countries/territory (tons of pure heroin equivalent), 2009-2012 average

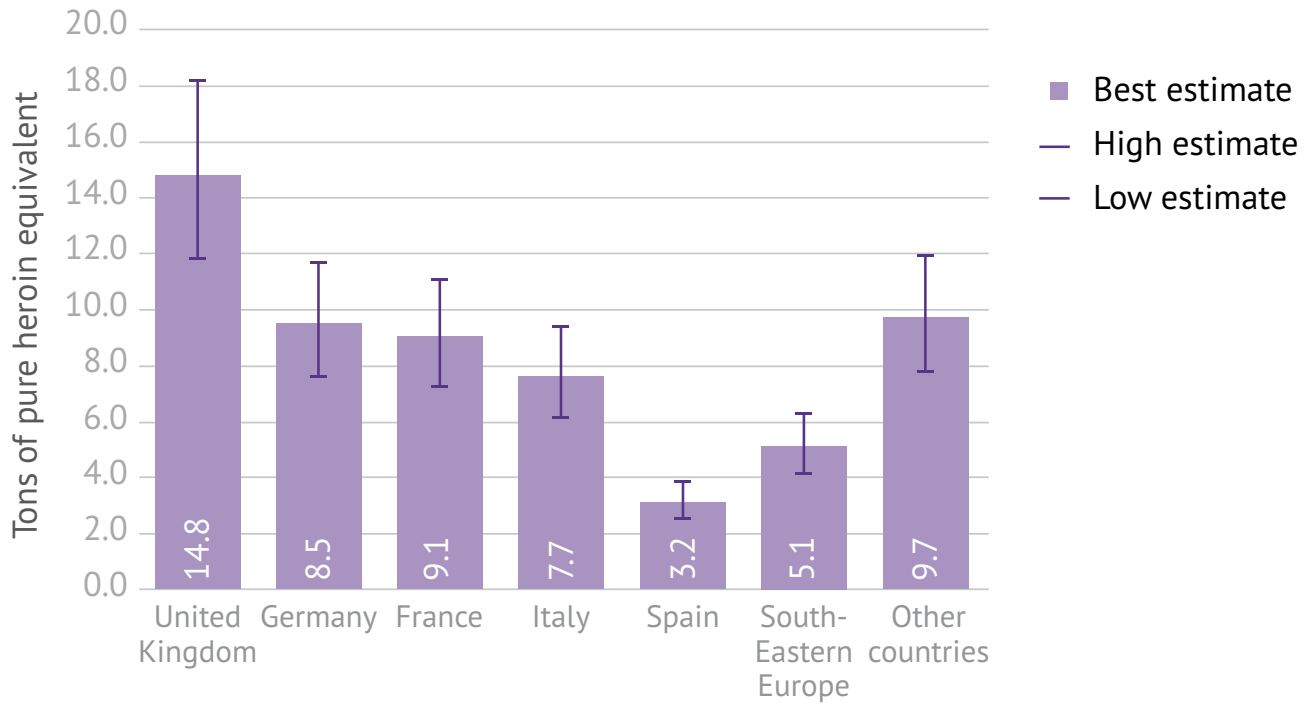

Note: "Other countries" are Austria, Belgium, Czech Republic, Denmark, Hungary, Ireland, Luxembourg, Norway, Poland, Portugal, Slovakia, Slovenia, Sweden, Switzerland, the Netherlands and Turkey. Low, best and high estimates depend on different assumptions on the per-user annual consumption of heroin.

Source: based on UNODC data.

Figure 9. Domestic consumption and seizures of opiates in the Balkan route countries/territory (kilograms of pure heroin equivalent), 2009-2012 average

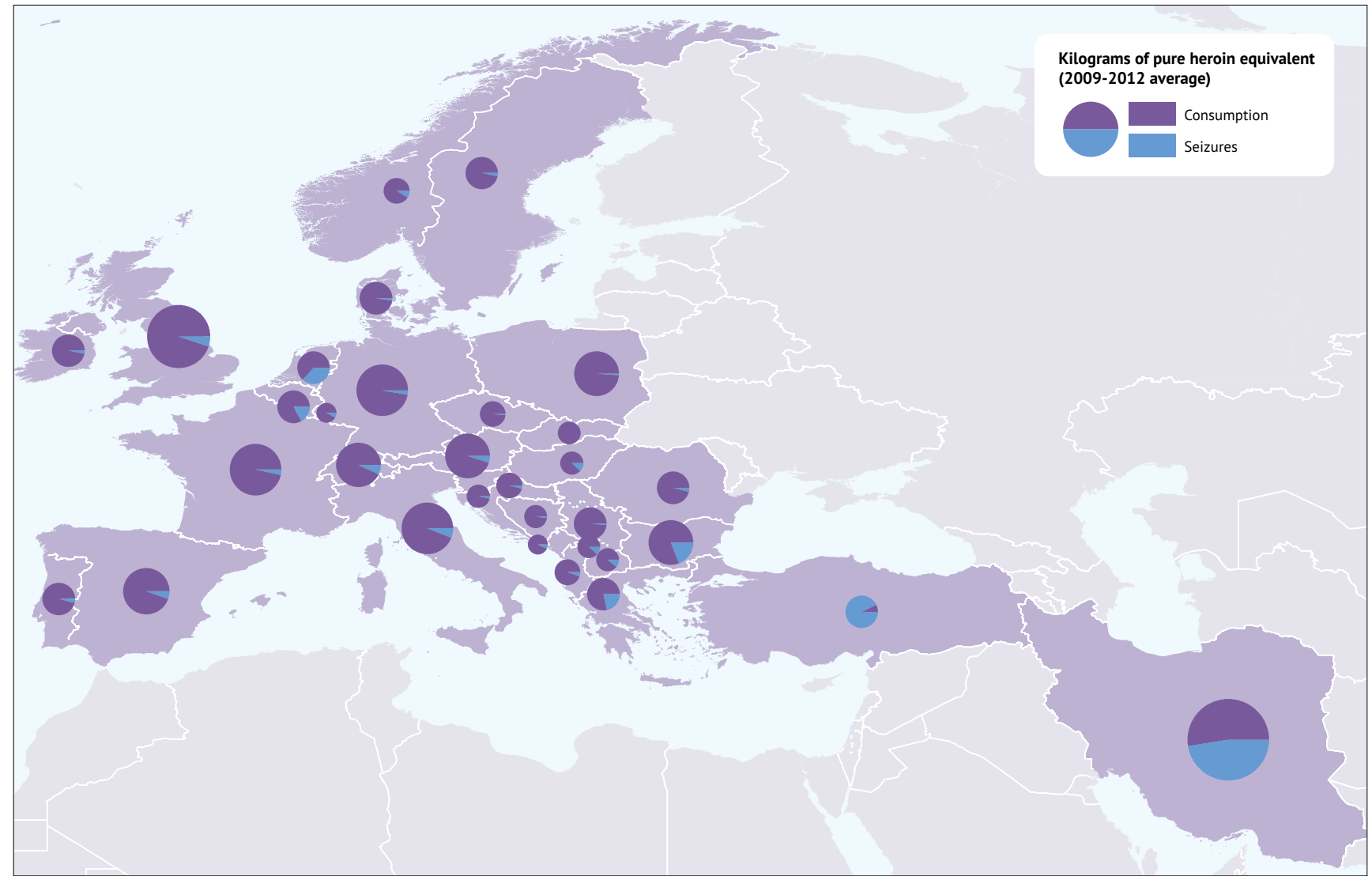

Note: the boundaries and names shown and the designations used on this map do not imply official endorsement or acceptance by the United Nations. The map depicts the total amount of illicit opiates available on the Balkan route in a year (2009-2012 average). This amount corresponds to total final consumption plus seizures. The map represents the best estimate of consumption.

Source: based on UNODC data. 


\subsection{Assessing the flow of illicit opiates on the Balkan route}

The next step in estimating the monetary value of opiates trafficked on the Balkan route is to assess the flow of opiates trafficked through each country, in addition to the combined quantity of illicit opiates consumed and seized. To assess this flow a network consisting of countries and connections between each country has to be built. A country is connected to another whenever there is a direct flow of opiates between them. This is very likely between neighbouring countries such as Turkey and Bulgaria, but it can also be the case between countries that do not share a land border, such as Turkey and the Netherlands.

The network in this study was built by analysing individual seizure cases and information on provenance and destination countries from ARQs. ${ }^{47}$ Some of the seizure cases recorded reported information on the producing or manufacturing country, departure or obtained country and destination country. ${ }^{48}$ This information enables the identification of flows that connect pairs of countries. ${ }^{49}$ The resulting network provides interesting insights into opiate trafficking routes through Europe.

Figure 10. Flow of opiates trafficked through individual countries

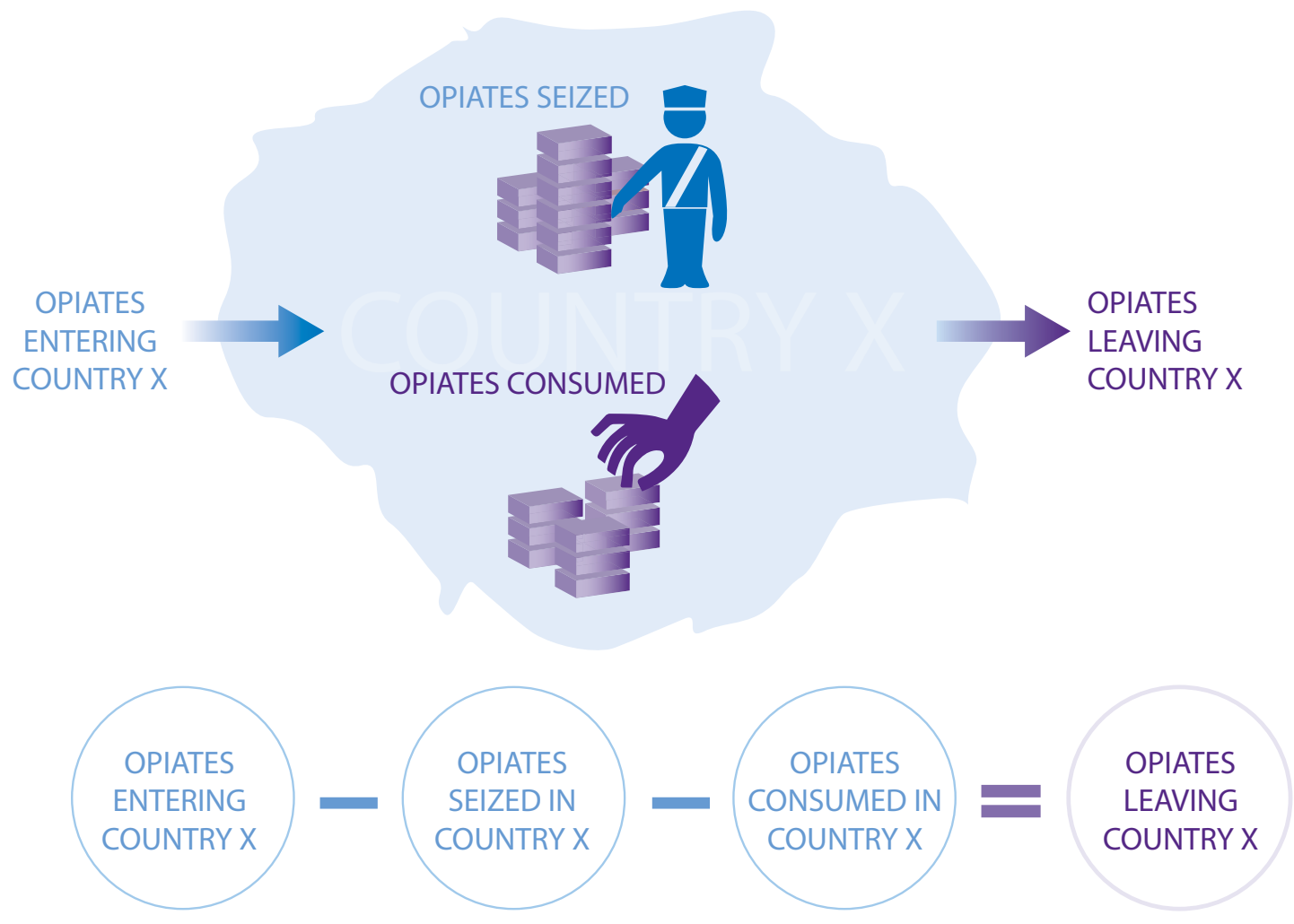

\footnotetext{
${ }^{47}$ Rémi Boivin, "Macrosocial Network Analysis: The Case of Transnational Drug Trafficking," in Networks and Network. Analysis for Defence and Security, ed. Anthony J. Masys, Lecture Notes in Social Networks (Springer International Publishing, 2014), 49-61, http://link.springer.com/ch apter/10.1007/978-3-319-04147-6_3; Siddharth Chandra and Johnathan Joba, "Transnational Cocaine and Heroin Flow Networks in Western Europe: A Comparison,” International Journal of Drug Policy, 2015, doi:10.1016/j.drugpo.2015.04.016.

${ }^{48}$ UNODC, Afghan Opiate Trade Project, and Paris Pact, Drugs Monitoring Platform, Drugs Monitoring Platform, 2015, http:// drugsmonitoring.unodc-roca.org/; UNODC, Delta Annual Reports Questionnaire Database (UNODC, 2014); UNODC, "Individual Drug Seizures," Drugs Monitoring Platform, 2014, https://data.unodc.org/\#state:0.

${ }^{49}$ For example, a seizure case reported by Serbia, which indicates Turkey as "departure or obtained country" and Austria as "destination country", enables the identification of two links within the network: exporter Turkey/importer Serbia and exporter Serbia/importer Austria. Seizure-Delta ARQ is the primary source of data used to construct the network. Seizure cases in 2007-2012 are considered. The time span of information on seizures is longer than that for other data used in the model because of a shortage of data, which would cause a reduction in the geographical scope of the study. Whenever a country is not included in Seizure-Delta ARQ, but is included in the IDS online database of UNODC, this database becomes the primary source of data for the country. Whenever a country of interest is not included in any of these databases, data on seizures are collected from the Drug Monitoring Platform. All available seizure cases collected from the IDS online database and the Drug Monitoring Platform are included in the analysis regardless of the year of their occurrence.
} 
By merging this network with each country's combined quantity of illicit opiates consumed and seized it is possible to estimate the quantity trafficked from one country to another..$^{50}$ To do that, it is assumed that the quantity of illicit Afghan opiates that enters each Balkan route country is equal to each country's combined quantity of illicit opiates consumed and seized, plus the quantity of illicit opiates trafficked from each country to other Balkan route countries.

Based on information on individual seizures, the distribution of the quantities seized in each country was mapped according to their destination, so that the volume traded between each pair of countries could be estimated.

\subsubsection{Country connections}

Among the 1,056 possible connections between the Balkan route countries only 98 were actually identified, showing that opiate trafficking is actually concentrated into just a few specific paths (chains of countries) on the Balkan route.

When analysing the network, Turkey stands out as a key transit country between Afghanistan, the Islamic Republic of Iran and the other Balkan route countries. Turkey receives the vast majority of heroin trafficked through the Islamic Republic of Iran, an important part of which ${ }^{51}$ is subsequently trafficked either directly to final destination markets such as Italy, Germany or France, to redistribution centres such as the Netherlands (from where heroin is trafficked to other European countries) and to the countries of South-Eastern Europe.

Twenty-two further links connect the Balkan route countries to countries that do not form part of the Balkan route, but the quantities of opiates trafficked are very small. The countries with the largest number of outward connections are Turkey, Bulgaria and the Netherlands. Slovenia and Switzerland are the countries to where illicit opiates are trafficked from the largest number of other countries.

\subsubsection{Flow of opiates}

Although a small quantity of illicit Afghan opiates reach the Islamic Republic of Iran through Pakistan, the vast majority of them reach the Islamic Republic of Iran directly from Afghanistan. In the 2009-2012 period, an average of 154.8 tons of illicit opiates in pure heroin equivalent per year crossed the border from Afghanistan to the Islamic Republic of Iran. As mentioned earlier, Illicit opiates enter the Islamic Republic of Iran in the form of both raw opium and refined heroin, but thereafter the illicit opiate trade on the Balkan route almost exclusively concerns refined products. ${ }^{52}$ The quantity of illicit opiates consumed in the Islamic Republic of Iran is estimated at around 33 per cent of the total quantity of opiates entering the country, which also seizes another 30 per cent of all opiates trafficked on the Balkan route, while traffickers move the rest further along the route.

Figure 11. Illicit opiate trafficking from Afghanistan to Europe (tons of pure heroin equivalent), 2009-2012 average

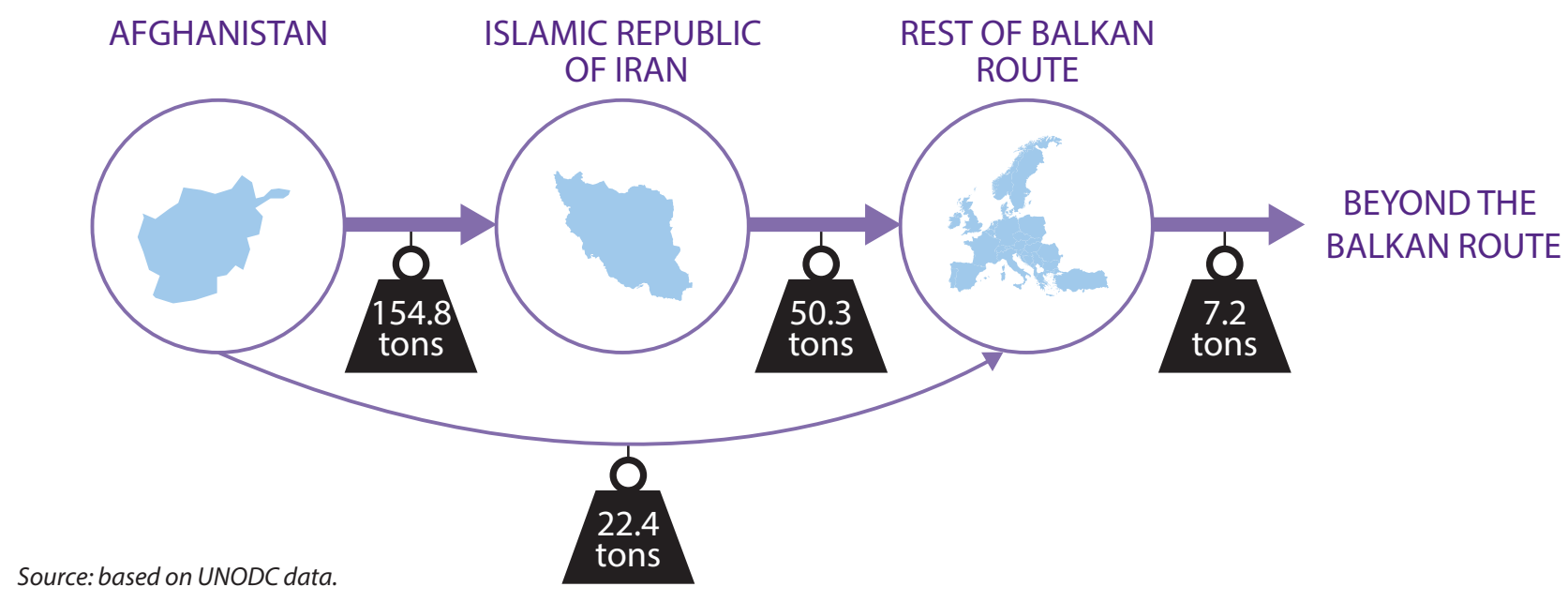

\footnotetext{
${ }^{50}$ To assess the amount of illicit opiates traded through the links, a country is assumed to acquire an amount of drugs equal to the sum of internal consumption and seizures, plus what is shipped further to other countries.

${ }^{51}$ UNODC, The Global Afghan Opium Trade (Vienna, 2011).

${ }^{52}$ Ibid.
} 
Between 42.3 and 59.1 tons of illicit opiates were trafficked annually from the Islamic Republic of Iran to Turkey in 2009-2012, which has 19 connections to other European countries. Shipments from Turkey reach transit nodes such as Bulgaria (10.3 tons), the Netherlands (4.2 tons) and Albania (1.4 tons), as well as main consumer markets such as Germany (6.2 tons), France (5.6) and Italy (2.4) (see Figure 12).

After Turkey, Bulgaria has a pivotal position in the trade both in terms of the quantity of illicit opiates trafficked (11.5 tons entering the country and 10.1 tons leaving the country) and its connections to other countries ( 2 inward links and 14 outward links) (see Figure 12). Like Turkey, Bulgaria is also a transit point for illicit opium flowing to other countries in South-Eastern Europe (1.6 tons to Romania, 1.0 tons to the former Yugoslav Republic of Macedonia, 0.8 tons to Serbia, 0.6 tons to Croatia, etc.) and the large consumer markets of Western and Central Europe (1.5 tons to Germany, 1.5 tons to Italy, etc.). In general, the majority of the illicit opiates that enter most of the countries in SouthEastern Europe also leave those countries, making the sub-region an important transit point for opiates bound for Western and Central Europe (see Figure 13).

Figure 12. The illicit opiate trafficking network on the Balkan route (kilograms of pure heroin equivalent), 2009-2012 average
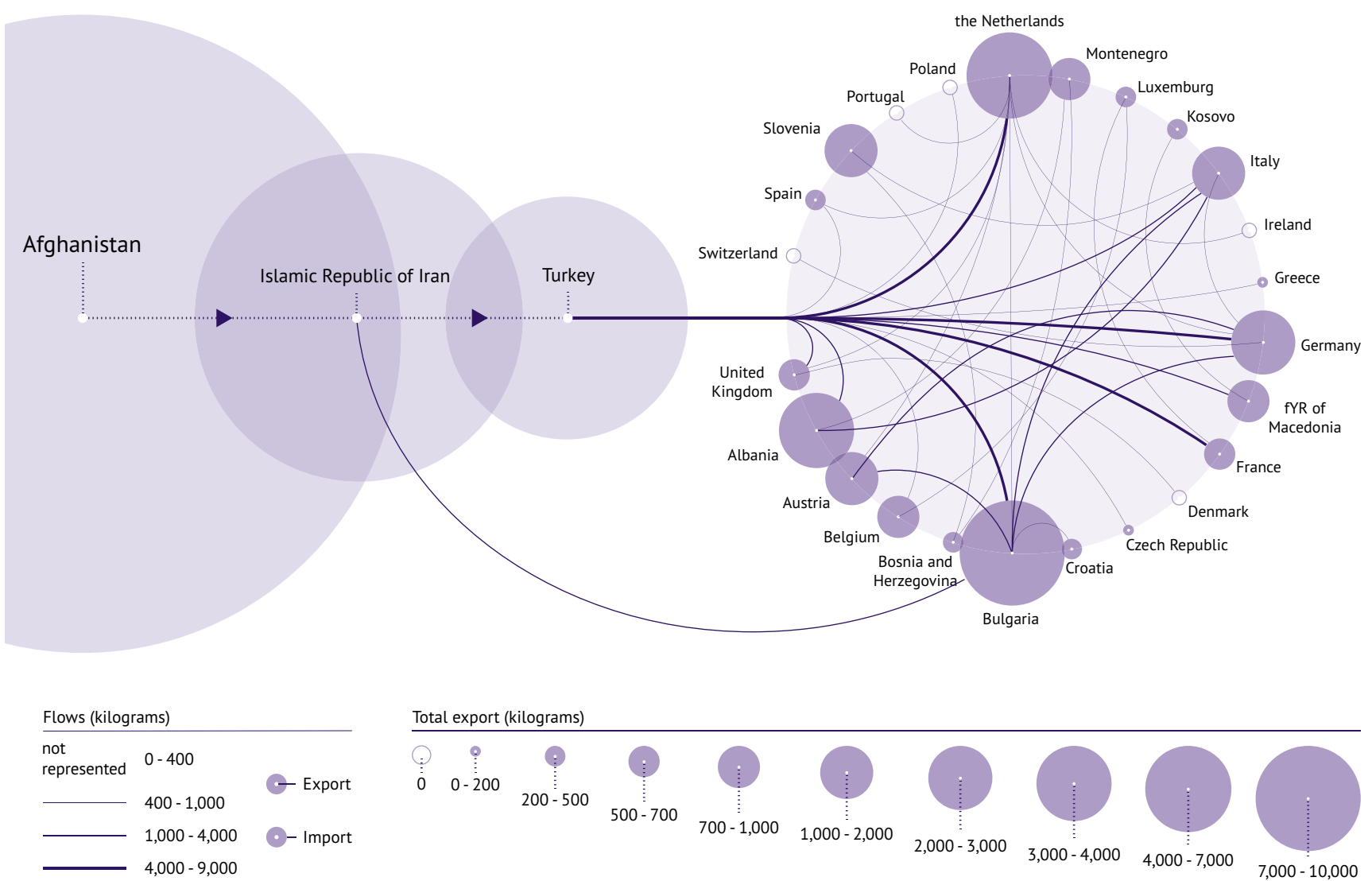

Note: the infographic represents the best estimate.

Source: based on UNODC data.

With the exception of Belgium and the Netherlands, most Western and Central-European countries consume the majority of the illicit opiates that enter their territory, with only very small amounts being subsequently trafficked elsewhere (see Figure 13). Illicit opiates do not tend to leave Denmark, Ireland, Norway, Portugal, Sweden and Switzerland for other countries. Turkey, the countries of South-Eastern Europe, Belgium and the Netherlands are the main transit countries for illicit opiates bound for the final destination markets in Western and Central Europe, although some of those markets also receive illicit opiates via the southern route and the northern route, or directly from Pakistan. 
Belgium and the Netherlands act as hubs for the trafficking of illicit opiates on the Balkan route, with more than three-quarters of the illicit opiates that enter the Netherlands (8 outward links) and Belgium (6 outward links) being subsequently trafficked to other countries. In fact, some 4.7 tons of pure heroin per year (range: 3.8-5.7 tons) are subsequently trafficked out of the Netherlands, the fourth-largest quantity of opiates trafficked from a country on the Balkan route. The main markets for illicit opiates transiting the Netherlands are consumer countries such as the United Kingdom (1.3 tons), France (1.0 tons), Germany (0.7 tons), Austria ( 0.5 tons), Ireland ( 0.5 tons), Portugal (0.4 tons) and Spain (0.3 tons).

Germany and Austria highlight the complexity of the European opiate trafficking network. Both countries act as transit countries for illicit opiates trafficked from the Balkan Peninsula en route to the Netherlands, while traffickers in the Netherlands subsequently traffic heroin, typically in smaller shipments, to Germany and, to a lesser extent, to Austria.

Figure 13. Share of illicit opiates trafficked out of each Balkan route country/territory (percentage), 2009-2012 average

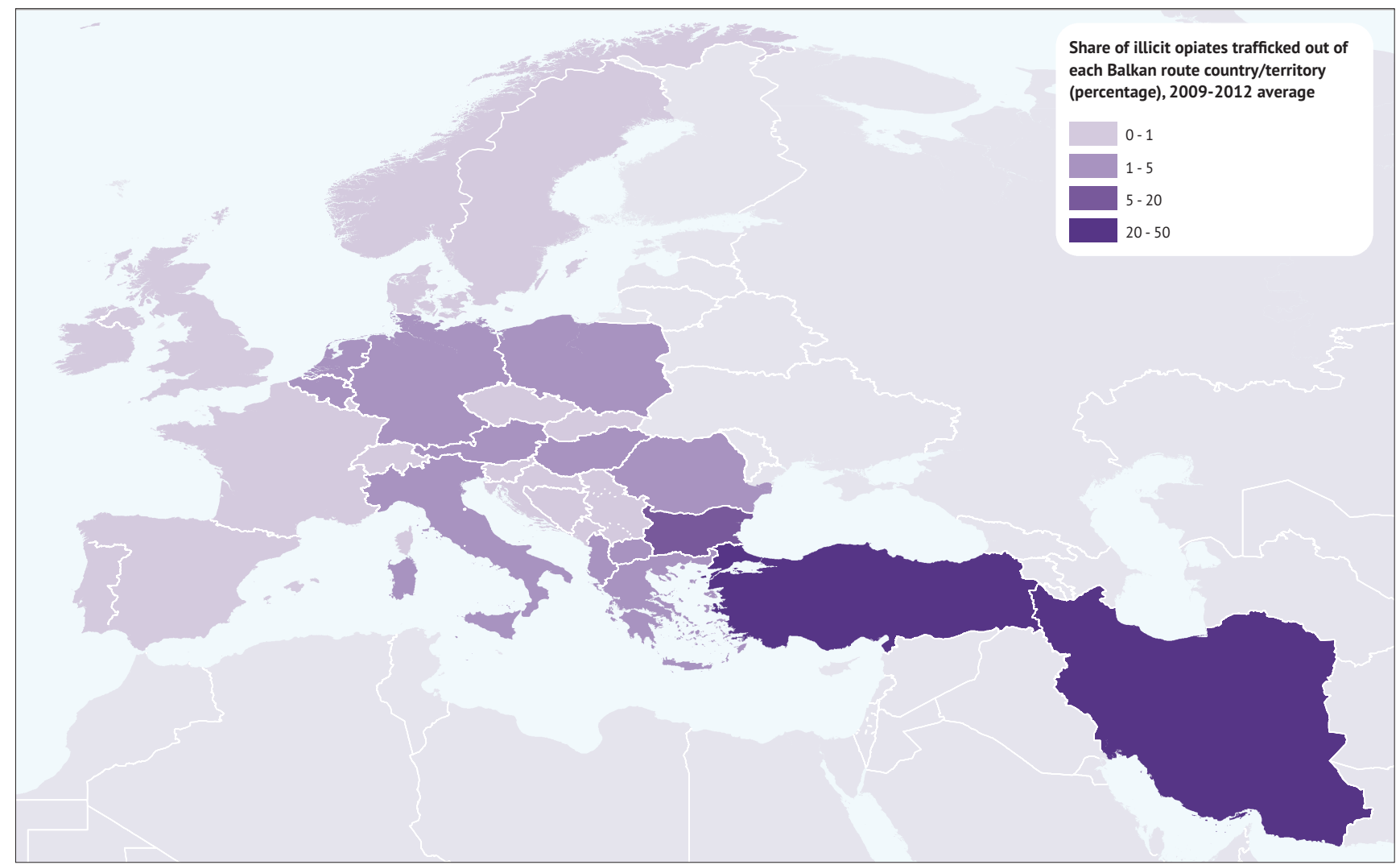

Note: the boundaries and names shown and the designations used on this map do not imply official endorsement or acceptance by the United Nations. The map does not represent Afghanistan. Afghanistan is the source of several opiate trafficking routes ${ }^{53}$ and the share of exports to the Balkan route countries is not representative of the country's actual export share. The map represents the best estimate.

\section{Box 4. The network of illicit opiates beyond the Balkan route}

Although the vast majority (154.8 tons) of the illicit opiates entering Europe are trafficked on the Balkan route via the Islamic Republic of Iran), ${ }^{54}$ they do not fully satisfy European demand. An estimated further 22.5 tons (range: 18.1-27.3 tons) of pure heroin equivalent enter Europe via the southern route or directly from Pakistan. At the same time, traffickers in several countries supplied with opiates via the Balkan route subsequently traffic illicit opiates beyond the Balkan route (7.2 tons; range: 6.5 to 8 tons).

\footnotetext{
${ }^{53}$ UNODC, The Global Afghan Opium Trade (Vienna, 2011).

${ }^{54}$ UNODC, The Illicit Drug Trade through South-Eastern Europe, (Vienna, 2014).
} 


\subsubsection{Interception rates}

The trafficking flows decribed above enable the estimation of the interception rate, which is the share, seized by law enforcement authorities, of opiates trafficked into a country.

The amount seized depends on a number of factors. Firstly, countries close to source, through which large quantities of opiates are trafficked, are able to seize large proportions of illicit opiates because shipments are made in large consignments when trafficked at the international trade level. Secondly, the more shipments of illicit drugs that cross a border, the more likely it is that shipments are detected. Therefore, the following table should not be considered a ranking, but rather as a description of the current situation and as a basis for future trend analysis.

One of the two main transit countries for Afghan opiates, the Islamic Republic of Iran seizes an annual average of 46.7 tons of opiates, which means that the country intercepts almost a third (30.2 per cent) of all illict Afghan opiates crossing its borders. Turkey, through which opiates are channeled to the main European consumer markets, intercepts an annual average of 16.7 per cent of all opiates trafficked through its territory (corresponding to 8.4 tons seized).

Ranging between 0.6 per cent and 8.7 per cent, annual average interception rates are considerably lower further west on the Balkan route. At 8.7 per cent, Norway intercepts a relatively high share of opiates, as do Switzerland (6.9 per cent), Greece (6.9 per cent) and the Netherlands (6.4 per cent).

Table 3. Interception rates of opiates trafficked on the Balkan route, by country/territory,2009-2012 average

\section{Interception rate}

\begin{tabular}{|c|c|c|c|}
\hline & Low estimate & Best estimate & High estimate \\
\hline \multirow{2}{*}{$\begin{array}{l}\text { Albania } \\
\text { Austria }\end{array}$} & $0.7 \%$ & $0.8 \%$ & $1.0 \%$ \\
\hline & $1.8 \%$ & $2.2 \%$ & $2.8 \%$ \\
\hline \multirow{2}{*}{$\begin{array}{l}\text { Belgium } \\
\text { Bosnia and Herzegovina }\end{array}$} & $3.5 \%$ & $4.2 \%$ & $5.2 \%$ \\
\hline & $1.3 \%$ & $1.5 \%$ & $1.9 \%$ \\
\hline Bulgaria & $1.9 \%$ & $2.3 \%$ & $2.8 \%$ \\
\hline Croatia & $2.3 \%$ & $2.8 \%$ & $3.5 \%$ \\
\hline Czech Republic & $1.1 \%$ & $1.4 \%$ & $1.7 \%$ \\
\hline Denmark & $1.9 \%$ & $2.3 \%$ & $2.9 \%$ \\
\hline France & $2.6 \%$ & $3.2 \%$ & $4.0 \%$ \\
\hline fYR of Macedonia & $1.3 \%$ & $1.6 \%$ & $2.0 \%$ \\
\hline \multirow{2}{*}{$\begin{array}{l}\text { Germany } \\
\text { Greece }\end{array}$} & $1.8 \%$ & $2.2 \%$ & $2.8 \%$ \\
\hline & $5.7 \%$ & $6.9 \%$ & $8.4 \%$ \\
\hline Hungary & $1.2 \%$ & $1.5 \%$ & $1.9 \%$ \\
\hline Iran (Islamic Republic of) & $27.2 \%$ & $30.2 \%$ & $33.5 \%$ \\
\hline Ireland & $2.3 \%$ & $2.9 \%$ & $3.6 \%$ \\
\hline \multirow{2}{*}{$\begin{array}{l}\text { Italy } \\
\text { Kosovo }\end{array}$} & $3.9 \%$ & $4.8 \%$ & $5.9 \%$ \\
\hline & $2.9 \%$ & $3.6 \%$ & $4.4 \%$ \\
\hline Luxembourg & $1.5 \%$ & $1.8 \%$ & $2.3 \%$ \\
\hline Montenegro & $0.9 \%$ & $1.1 \%$ & $1.3 \%$ \\
\hline Netherlands & $5.3 \%$ & $6.4 \%$ & $7.9 \%$ \\
\hline Norway & $7.2 \%$ & $8.7 \%$ & $10.7 \%$ \\
\hline Poland & $0.5 \%$ & $0.6 \%$ & $0.8 \%$ \\
\hline Portugal & $3.2 \%$ & $3.9 \%$ & $4.8 \%$ \\
\hline Romania & $1.3 \%$ & $1.5 \%$ & $1.9 \%$ \\
\hline Serbia & $0.6 \%$ & $0.8 \%$ & $1.0 \%$ \\
\hline Slovakia & $0.7 \%$ & $0.8 \%$ & $1.0 \%$ \\
\hline Slovenia & $0.8 \%$ & $1.0 \%$ & $1.2 \%$ \\
\hline Spain & $3.9 \%$ & $4.8 \%$ & $5.9 \%$ \\
\hline Sweden & $2.6 \%$ & $3.2 \%$ & $4.0 \%$ \\
\hline Switzerland & $5.7 \%$ & $6.9 \%$ & $8.5 \%$ \\
\hline Turkey & $14.2 \%$ & $16.7 \%$ & $19.8 \%$ \\
\hline United Kingdom & $4.0 \%$ & $4.8 \%$ & $6.0 \%$ \\
\hline
\end{tabular}


Figure 14. Interception rate: the percentage intercepted of all opiates entering the Balkan route countries/ territory

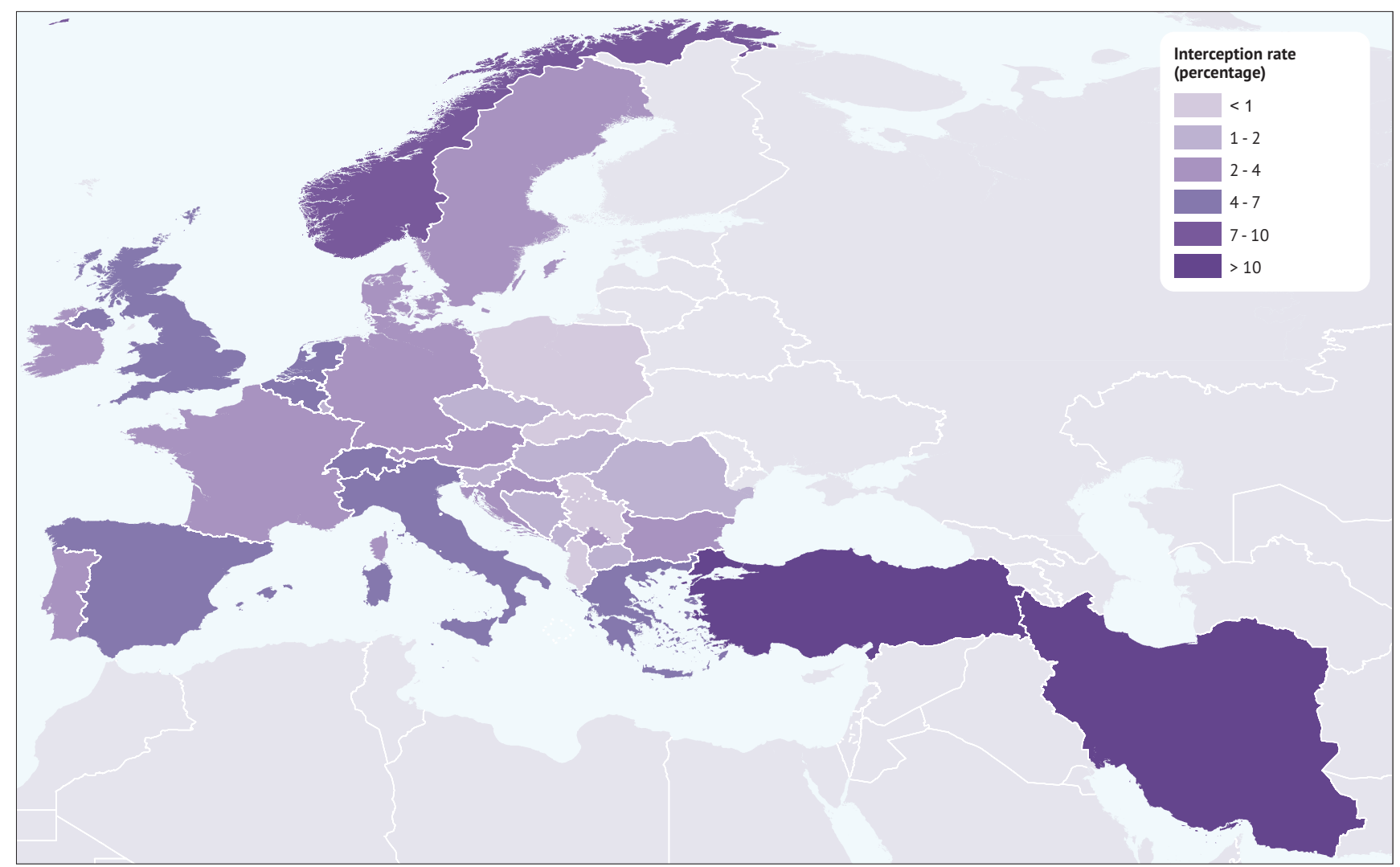

Note: the boundaries and names shown and the designations used on this map do not imply official endorsement or acceptance by the United Nations.

\subsection{Estimating the gross profit made from the trafficking of illicit opiates on the Balkan route}

The monetary value of illicit opiates trafficked on the Balkan route is effectively the gross profit made from this activity by traffickers (in economic terms, value added). The term denotes the gross income received from the international trade, national distribution and retail sales of illicit opiates, minus the costs necessary to buy and/or produce them, which do not include costs such as salaries, bribes, etc.

Gross profit made from illicit opiate trafficking on the Balkan route is estimated by combining the quantities of opiates trafficked with the prices of illicit opiates in the Balkan route countries at the retail, wholesale and international trade levels..$^{55}$

\subsubsection{Breaking gross profit down into its components}

International, wholesale and retail trade are the three components of the gross profit made from opiate trafficking. International trade refers to the trade level at which large quantities (more than $10 \mathrm{~kg}$ ) of illicit opiates are trafficked across international borders, as well as to their distribution to wholesalers in final markets. ${ }^{56}$ Wholesale refers to the handling of large quantities (larger than $1 \mathrm{~kg}$ but smaller than $10 \mathrm{~kg}$ ) of illicit opiates domestically. ${ }^{57}$ Retail refers to

\footnotetext{
55 The estimate of the gross profit of the countries on the Balkan route considers the entire volume trafficked in those countries despite the fact that a certain amount reaches the European markets via other routes.

${ }^{56}$ FATF/OECD, Financial Flows Linked to the Production and Trafficking of Afghan Opiates.

${ }^{57}$ EMCDDA, Pilot Study on Wholesale Drug Prices in Europe (Lisbon, 2011).
} 
the sale of illicit opiates to final consumers. ${ }^{58}$ The importance of these three components varies according to the role a country plays in the trafficking network, national consumption and purity-adjusted prices in that country.

The estimate indicates that the total average annual gross profit made from opiate trafficking on the Balkan route amounts to $\$ 28.0$ billion (range: $22.4-34.2$ billion), a sum 30 per cent bigger than the entire GDP of Afghanistan itself. Retail accounts for 54 per cent of total gross profit ( $\$ 15.1$ billion; range: $12.0-18.5$ ), international trade for 30 per cent ( $\$ 8.3$ billion; range: 6.7-10.0) and wholesale for 16.4 per cent ( $\$ 4.6$ billion; range: 3.6-5.6).

Retail is the main component of the gross profit in 28 Balkan route countries (see Figure 15), while international trade is the most important component in key transit country Turkey ( 95 per cent of national gross profit), the Netherlands (73 per cent), Bulgaria (58 per cent) and Hungary (54 per cent). In all the Balkan route countries, wholesale accounts for the smallest share of gross profit, although it ranges from 1.5 per cent of gross profit in Turkey to more than 25 per cent in Bosnia and Herzegovina, Italy, Croatia and Ireland.

Figure 15. Shares of the three components of the gross profit made from illicit opiate trafficking on the Balkan route (millions of United States dollars), by country/territory 2009-2012 average

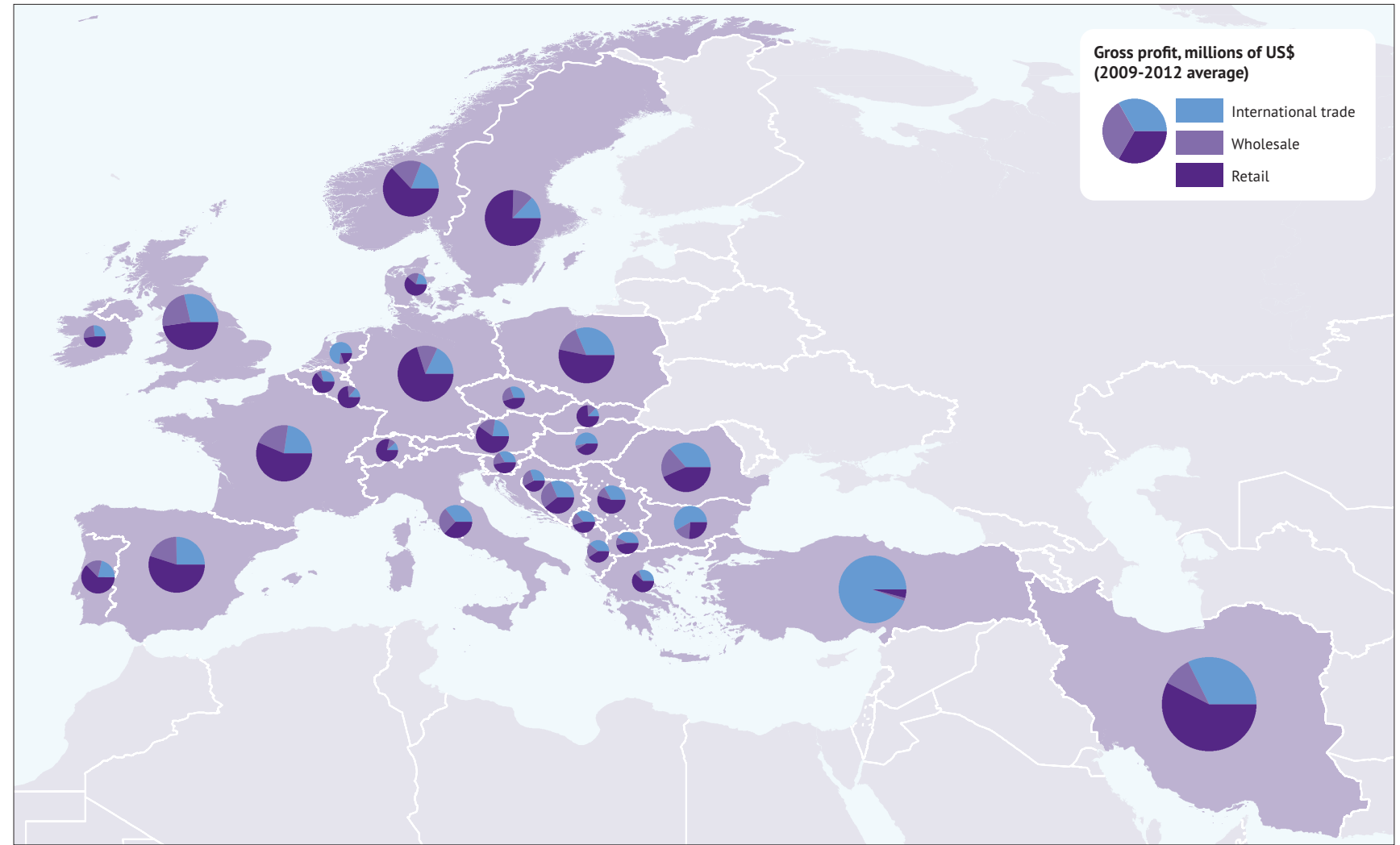

Note: the boundaries and names shown and the designations used on this map do not imply official endorsement or acceptance by the United Nations. The map does not represent Afghanistan because the sub-division of the gross profit from illicit opiates made by traffickers in that country is not fully comparable with that made in other countries. International trade takes into account only shipments to the rest of the Balkan route, while Afghanistan exports illicit opiates in multiple directions. The map represents the best estimate.

Source: based on UNODC data.

\subsubsection{Gross profit by sub-region and country}

The large quantity of opiates traded across the Islamic Republic of Iran in addition to a high level of domestic consumption of opiates mean that, at $\$ 7.5$ billion and accounting for 27 per cent of the total, the annual average gross profit made in the Islamic Republic of Iran is the highest of any single country on the Balkan route.

\footnotetext{
${ }^{58}$ FATF/OECD, Financial Flows Linked to the Production and Trafficking of Afghan Opiates; Executive Office of the President Office of National Drug Control Policy, “Technical Report for The Price and Purity of Illicit Drugs: 1981 Through the Second Quarter of 2003” (Washington D.C, November 2004), https://www.ncjrs.gov/ondcppubs/publications/pdf/price_purity_tech_rpt.pdf.
} 
However, the large consumer markets in the countries at the western end of the Balkan route together account for the largest share of total gross profit made from the trafficking of illicit opiates. Accounting for 64.7 per cent of the total gross profit generated on the entire Balkan route, the countries of Western and Central Europe have a combined gross profit of $\$ 18.1$ billion per annum (range: 14.4-22.2 billion); a sum larger than the GDP of Bosnia and Herzegovina..$^{59}$ The combined annual gross profit made in the four largest European markets accounts for nearly half of the total gross profit generated on the entire Balkan route, with $\$ 5.1$ billion made in France, $\$ 3.4$ billion in the United Kingdom, \$2.6 in Germany and \$1.5 in Italy. High consumption and high purity-adjusted price at retail explain the magnitude of the gross profit in those countries.

With the exception of the Islamic Republic of Iran, in the countries closer to the source (Afghanistan) of the opiates trafficked on the Balkan route, which act mainly as transit points, gross profits tend to be smaller despite the large flow of illicit opiates traversing them. Turkey, despite being the second main transit country on the Balkan route, is the prime example of this, as an average annual gross profit of $\$ 0.8$ billion from illicit Afghan opiates is made by traffickers in that country, only slightly more than a tenth of that made by traffickers in the Islamic Republic of Iran. Considering the large amount of illicit opiates flowing through the country, Turkey has a low prevalence of opiate use and the annual gross profit from illicit trafficking at the retail level is among the lowest in any of the Balkan route countries ( $\$ 0.03$ billion).

Annual consumption of heroin in the United Kingdom exceeds consumption in France by nearly 6 tons. Moreover, the retail price of heroin of unknown purity is higher in the United Kingdom (the average typical price in 20092012 was $\$ 65$ ) than in France (\$51), yet annual gross profit is greater in France than in the United Kingdom. The different paths by which heroin flows into the two countries explains this apparent contradiction. Indeed, larger quantities are shipped to the United Kingdom than to France from countries close to Afghanistan. Consequently, heroin purity at retail level is usually higher in the United Kingdom than in France. Furthermore, adjusting for the level of purity, the typical retail price of heroin in France (\$584 per gram in 2009-2012) was more than twice that in the United Kingdom (\$246).

\footnotetext{
${ }^{59}$ United Nations.
} 
Table 4. Total gross profit made from the trafficking of illicit opiates on the Balkan route (millions of United States dollars), by country/territory, 2009-2012 average

\begin{tabular}{|c|c|c|c|}
\hline & Low estimate & Best estimate & High estimate \\
\hline Albania & 255 & 320 & 392 \\
\hline Austria & 801 & 1,007 & 1,235 \\
\hline Belgium & 98 & 123 & 151 \\
\hline Bosnia and Herzegovina & 32 & 40 & 49 \\
\hline Bulgaria & 493 & 616 & 752 \\
\hline Croatia & 177 & 223 & 273 \\
\hline Czech Republic & 127 & 160 & 196 \\
\hline Denmark & 387 & 486 & 597 \\
\hline France & 4,041 & 5,079 & 6,233 \\
\hline Germany & 2,089 & 2,625 & 3,220 \\
\hline Greece & 174 & 218 & 267 \\
\hline Hungary & 41 & 51 & 63 \\
\hline Iran (Islamic Republic of) & 6,093 & 7,521 & 9,108 \\
\hline Ireland & 534 & 672 & 824 \\
\hline Italy & 1,208 & 1,518 & 1,862 \\
\hline Kosovo & 20 & 25 & 31 \\
\hline Luxembourg & 33 & 42 & 51 \\
\hline fYR of Macedonia & 31 & 39 & 47 \\
\hline Montenegro & 9 & 11 & 14 \\
\hline Netherlands & 148 & 183 & 223 \\
\hline Norway & 310 & 390 & 479 \\
\hline Poland & 221 & 277 & 340 \\
\hline Portugal & 126 & 158 & 194 \\
\hline Romania & 107 & 135 & 165 \\
\hline Serbia & 27 & 33 & 41 \\
\hline Slovakia & 106 & 133 & 163 \\
\hline Slovenia & 74 & 93 & 114 \\
\hline Spain & 571 & 717 & 880 \\
\hline Sweden & 435 & 547 & 671 \\
\hline Switzerland & 348 & 437 & 536 \\
\hline Turkey & 620 & 765 & 926 \\
\hline United Kingdom & 2,705 & 3,399 & 4,170 \\
\hline Balkan route & 22,442 & 28,044 & 34,268 \\
\hline Afghanistan & 349 & 357 & 366 \\
\hline
\end{tabular}

Note: different assumptions on per-user annual consumption of illicit opiates determine the three estimates (see Box A 10).

Source: based on UNODC data.

The total gross profit made by traffickers in the countries of South-Eastern Europe is estimated at $\$ 1.7$ billion (range: \$1.3-2.0 billion) per annum; less than a tenth of the total gross profit made on the entire Balkan route (see Figure 16). At $\$ 0.6$ billion, the annual gross profit made by opiate traffickers in Bulgaria is the highest in the sub-region. 


\section{Box 5. Monetary value in Afghanistan of illict opiates trafficked on the Balkan}

\section{route}

The monetary value of opiates supplied specifically to the Balkan route plus the monetary value generated by illicit opiates consumed in Afghanistan amounts to an annual average of $\$ 0.4$ billion. The estimate does not refer to the value of the entire Afghan opiate economy, which, in 2012, was estimated to be $\$ 2.0$ billion. ${ }^{60}$

Figure 16. Value of gross profit made from illicit opium trafficking in the European Balkan route countries/ territory (millions of United States dollars), 2009-2012 average

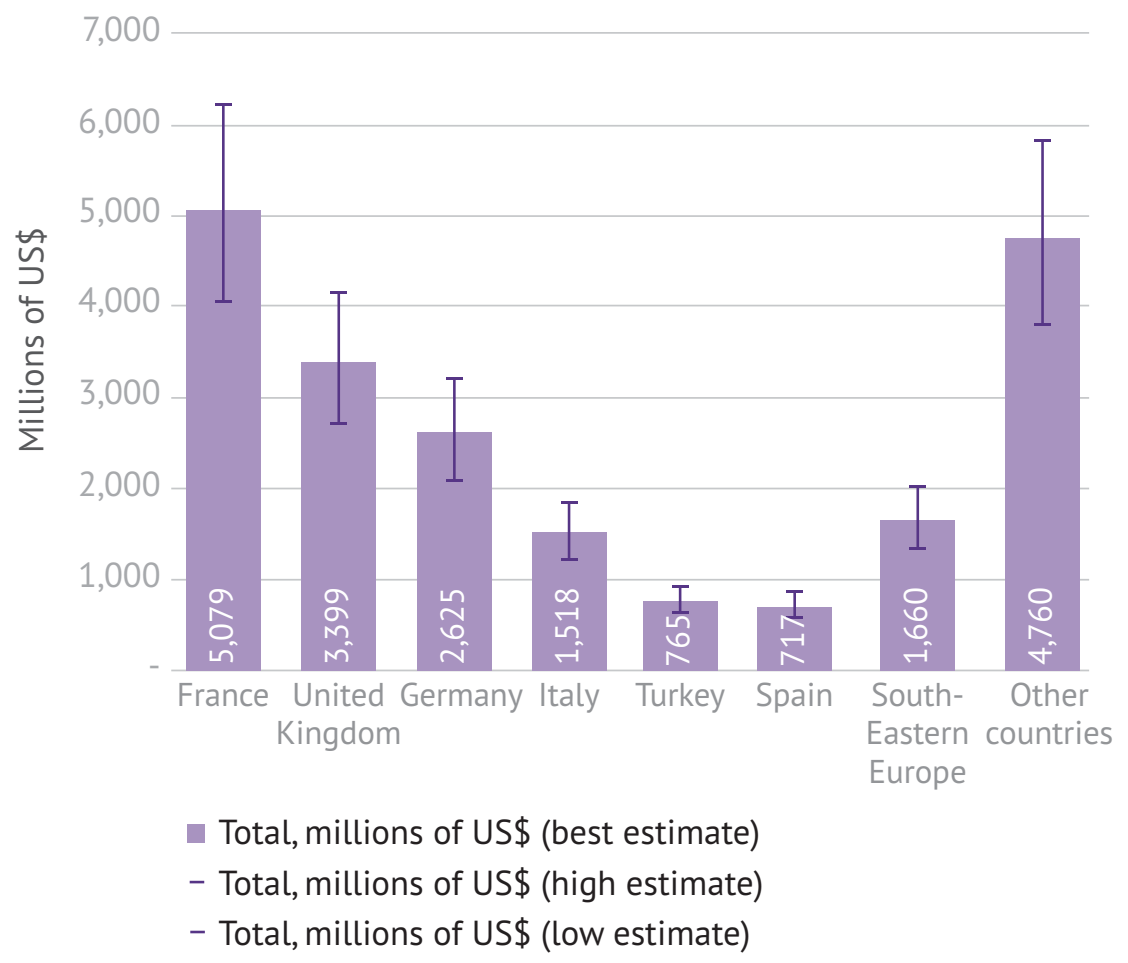

Note: "Other countries" are Austria, Belgium, Czech Republic, Denmark, Hungary, Ireland, Luxembourg, Norway, Poland, Portugal, Slovakia, Slovenia, Sweden, Switzerland and the Netherlands.

Source: based on UNODC data.

${ }^{60}$ UNODC and Islamic Republic of Afghanistan - Ministry of Counter Narcotics, Afghanistan Opium Survey 2013 (Vienna, 2013). 


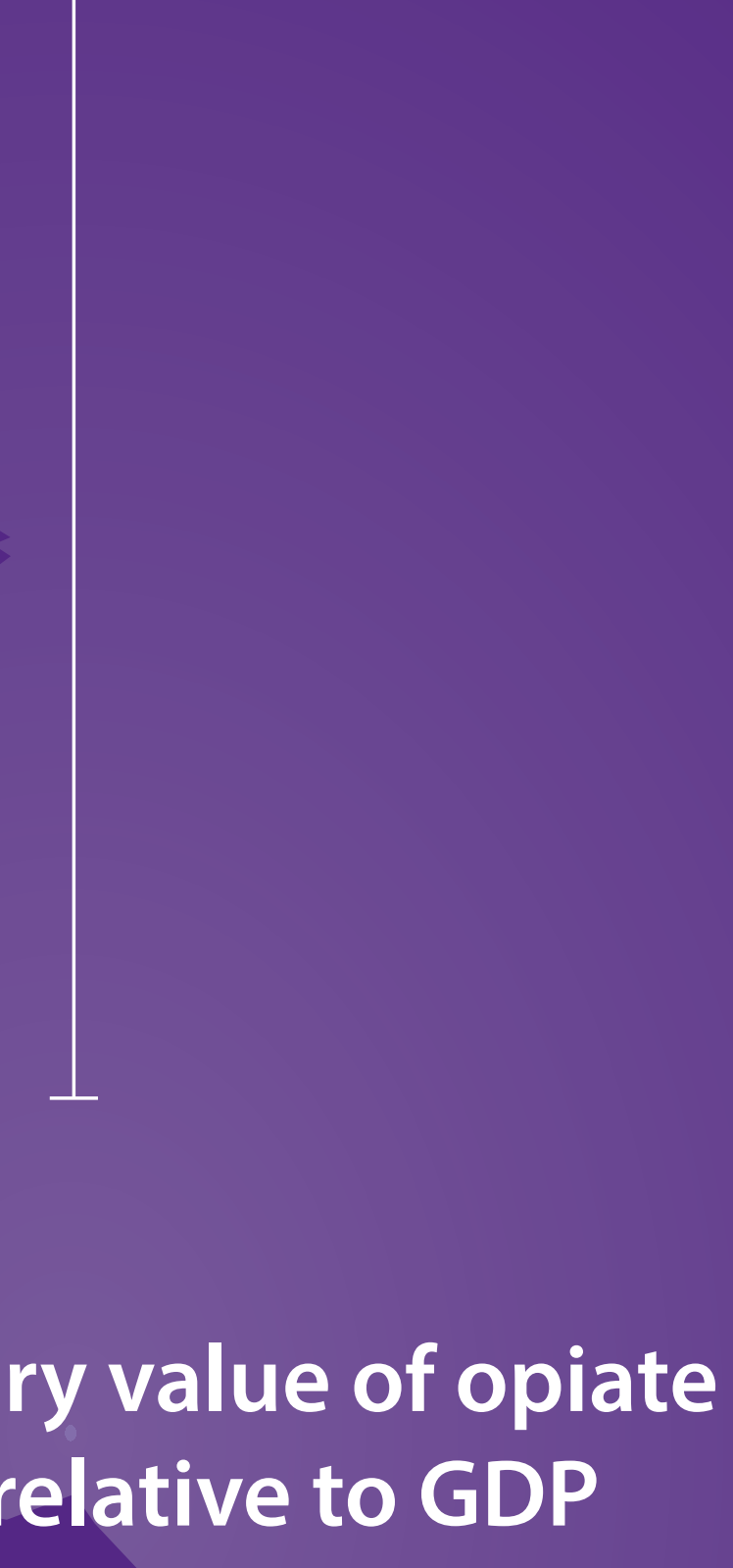





\section{3: The monetary value of opiate trafficking relative to GDP}

As the previous section shows, the total gross profit generated by the trafficking of illicit opiates on the Balkan route constitutes a sum comparable to the size of the GDP of some relatively large countries. But how does the gross profit generated in individual Balkan route countries compare with the GDP of those countries themselves? This section compares the estimate of the gross profit made form the trafficking of illicit opiates with the value of national GDP in order to gain insights into the potential economic effects of opiate trafficking in the Balkan route countries. ${ }^{61}$

If the monetary value of illicit opium trafficking accounts for a sizeable share of GDP, capital from opiate trafficking may compete with funds from the legal economy by introducing significant macroeconomic distortions. Illicit proceeds may influence foreign exchange flows, aggregate demand and inflation, and eventually economic growth in general. ${ }^{62}$ It is therefore important to determine the relative economic scale of opiate trafficking since its potential economic consequences depend not only on the amount of money that opiate trafficking generates, but also on its magnitude with respect to national economies. ${ }^{63}$ Moreover, estimating the size of the illicit opium trade in comparison to the size of economies may be of help in judging the relative merits of alternative counter-policies and programmes. ${ }^{64}$

\subsection{Total gross profit made from the trafficking of illicit opiates relative to GDP}

Although the share varies considerably across countries depending on the role they play in opiate trafficking and the size of their economy, the total annual gross profit made from opiate trafficking on the Balkan route is equal to 0.15 per cent of the combined GDP of all the Balkan route countries. At first glance, not a huge share but only slightly less than the share of GDP spent on foreign aid by some of the world's wealthiest countries. ${ }^{65}$

Accounting for 1.66 per cent of GDP (range: 1.34-2.01 per cent) and corresponding to an annual figure of $\$ 98.4$ per inhabitant, the monetary value of the illicit opiate trade is significant in the Islamic Republic of Iran. By contrast, although Turkey also plays a pivotal role in opiate trafficking on the Balkan route, the country has a relatively low opiate consumption rate and a GDP (an annual average of $\$ 727$ billion in 2009-2012) far larger than that of the Islamic Republic of Iran. The gross profit made from illicit opiate trafficking in Turkey therefore accounts for less than 0.11 per cent of GDP.

The monetary value of opiate trafficking is also considerable in several South-Eastern European countries. Albania (2.60 per cent of GDP) and Bulgaria (1.22 per cent of GDP), in particular, are the two Balkan route countries where the ratio between gross profit from opiate trafficking and GDP is the highest, which can be explained by the strategic location of those countries in the trafficking of opiates on the Balkan route. The monetary value of opiate trafficking is less significant in the largest countries in the sub-region, i.e. Serbia ( 0.08 per cent), Romania ( 0.08 per cent), and Greece ( 0.08 per cent).

However, in general, it is in the countries with smaller GDPs on the Balkan route that opiate trafficking has the greatest relative monetary value. This is underlined by the fact that, overall, the monetary value of illicit opium trafficking is an annual average of 0.11 per cent of the combined GDP of the Western and Central European countries, and while this sub-region is where the largest amount of gross profit is made on the Balkan route, it is where the pressure of opiate trafficking exerted on national economies is the smallest.

\footnotetext{
${ }^{61}$ GDP measures final purchases by households, businesses and governments by summing consumption, investment, government spending, and net exports. It is the most widely used proxy for economic development and allows the most comprehensive analyses of the impact of external events on the economy of a country. Since estimation of gross profit from illicit opium trafficking largely follows the process used to calculate national GDP, it is possible to compare these two values and gain a measure of the economic impact that opiate trafficking may have in each country on the Balkan route.

${ }^{62}$ UNDCP, Economic and Social Consequences of Drug Abuse and Illicit Trafficking (Vienna, 1998).

${ }^{63}$ Letizia Paoli, Victoria A. Greenfield, and Peter Reuter, The World Heroin Market: Can Supply Be Cut? (Oxford University Press, 2009).

${ }^{64}$ Sam Brand and Richard Price, The Economic and Social Costs of Crime (Home Office, Home Office Research Studies (London, 2000).

${ }^{65}$ US 0.19 per cent; Spain 0.16 per cent: OECD 2013.
} 
Figure 17. Gross profit as a share of GDP (percentages) in the Balkan route countries/territory, 2009-2012 average

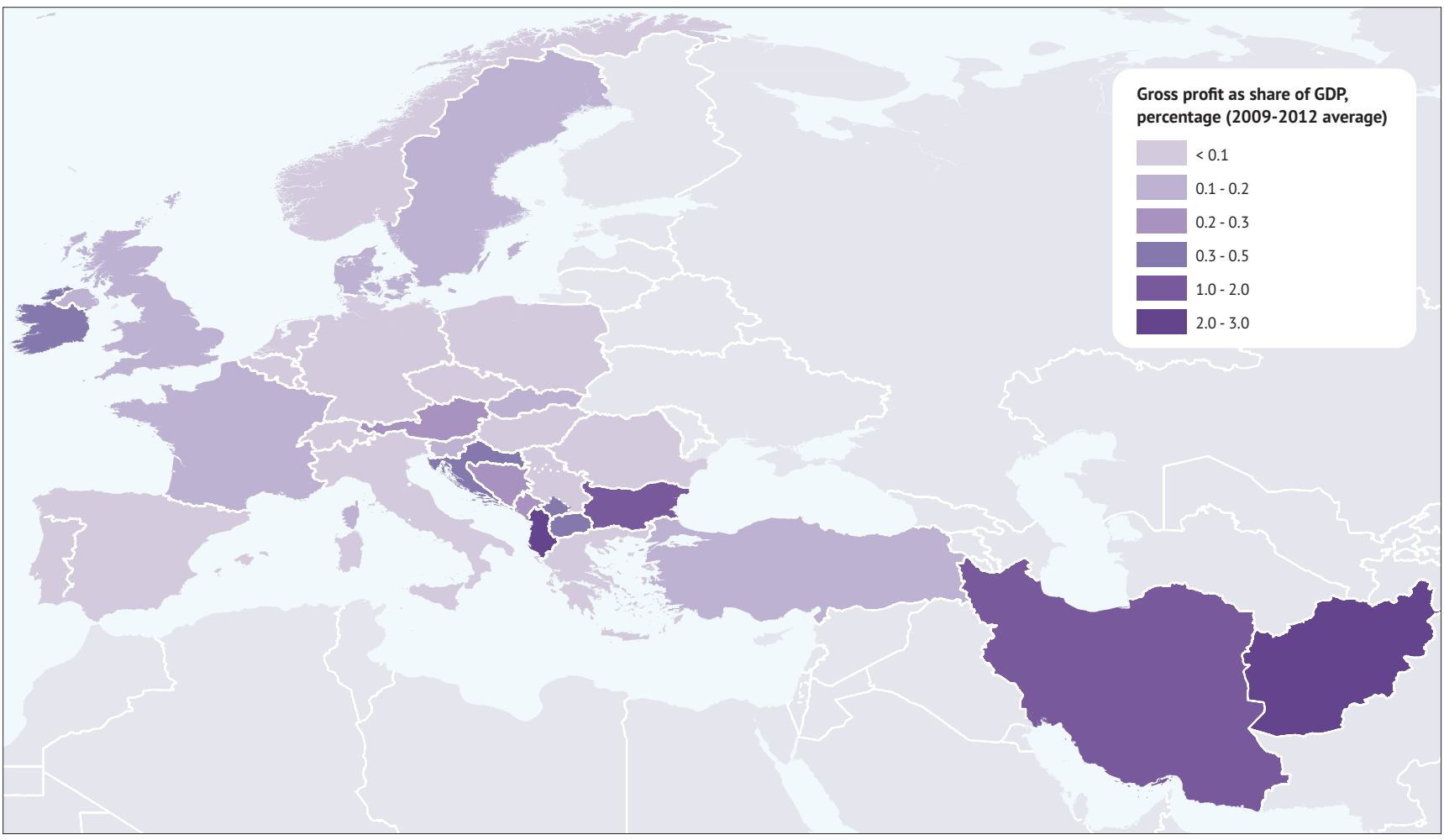

Note: the boundaries and names shown and the designations used on this map do not imply official endorsement or acceptance by the United Nations. The opiate economy accounts for a particularly large share of GDP in two transit countries, Albania and Bulgaria, and in the Islamic republic of Iran.

The opiate economy is worth 0.11 per cent of the GDP of the 22 European Union Member States included in the analysis. The map represents the best estimate.

Source: based on UNODC data.

The countries of Western and Central Europe, most of which have sizeable licit economies, are the main destination markets for Afghan opiates trafficked on the Balkan route. Yet the monetary value of those illicit opiates is quite different among the four main European markets. Gross profit is relatively high in France ( 0.19 per cent of GDP) and in the United Kingdom ( 0.14 of GDP), whereas it is 0.07 per cent in Italy and 0.08 per cent in Germany.

The Netherlands and Belgium are among the countries with the lowest ratios of gross profit to GDP on the Balkan route (0.02 and 0.03 per cent, respectively), notwithstanding their position as international trade hubs. In countries such as Ireland ( 0.31 per cent of GDP) and Austria ( 0.26 per cent of GDP), the potential spillover from the profit made from illicit opiate trafficking may be significant.

\section{Box 6. Beyond the economic dimension of the trafficking of illicit opiates}

If the clandestine nature of illicit opiate trafficking, its amplitude and complexity, and even uncertainties about its functioning, make estimating the gross profit made from the trafficking of illicit opiates a complex task, even more arduous is assessment of the broader range of indirect societal costs caused by such trafficking. Consequently, very few comprehensive and internationally comparative studies and measures of the costs to societies of drug trafficking and use are available. These studies differ from each other in the methodologies used, the assumptions made, or their geographical extent. Full understanding of the indirect societal costs of opiate trafficking in the Balkan route countries is beyond the scope of this study. Some of the possible spillovers into the economy and society in general caused by opiate trafficking are listed below.

The trafficking of illicit opiates may:

- retard economic growth by:

- offering criminal alternatives to legal employment 
- reducing investments, especially from abroad ${ }^{66}$

- causing productivity-related indirect costs (i.e. premature mortality due to drug use) ${ }^{67}$

- distort competition by:

- polluting the legal economy with illicit funds

- increase public expenditure by:

- boosting criminal justice system costs

- requiring healthcare treatment for illicit drug use

favour the development of organized criminal groups by:

- providing them with illicit funds

In addition to economic consequences, illicit drug use can also have a negative social impact, while the illicit drug economy may also encourage corrupt practices that have a detrimental impact on the social environment.

\subsection{Total gross profit made from illicit opium trafficking relative to drug-related public expenditure}

The European Monitoring Centre for Drugs and Drug Addiction (EMCDDA) monitors national drug-related expenditure incurred by governments. Drug-related public expenditure refers to portions of national budgets explicitly ("labelled") or implicitly ("non-labelled") dedicated to the implementation of drug policies: "labelled" and "nonlabelled" expenditure cover figures from official government budgets and an estimate of other expenditure not easily identifiable as being specifically devoted to the drugs issue (for example, routine law enforcement actions by the police). Generally speaking, drug-related public expenditures pertain to either of two categories: public order and safety (i.e. police services, law courts and prisons) and health (i.e. medical products, outpatient, hospital and public health services). ${ }^{68}$

Due to the range of political structures and government accounting systems present in Member States, estimating drug-related public expenditure is a challenge ${ }^{69}$ The following figures therefore have to be interpreted with caution, as shares are from different years and may not necessarily be comparable with each other. However, when looking at the differences between drug-related public expenditure and gross profit, the order of magnitude of the gross profit made from the trafficking of illicit opiates is shown. ${ }^{70}$

In all countries for which data are available, the gross profit made from the trafficking of illicit opiates is of the order of magnitude of drug-related public expenditure when compared with GDP. In many countries (Czech Republic, France, Ireland, Slovakia, Spain and Turkey), gross profit even exceeds drug-related public expenditure. This means that drug traffickers make roughly as much money, if not more, purely from opiates as Member States spend on addressing the drug issue.

\footnotetext{
${ }^{66}$ V. Daniele and U. Marani, “Organized Crime, the Quality of Local Institutions and FDI in Italy: A Panel Data Analysis," European Journal of Political Economy 27, no. 1 (2011): 132-42; Jan Van Dijk, The World of Crime: Breaking the Silence on Problems of Security, Justice and Development Across the World (Sage Publications, Inc, 2007).

${ }^{67}$ NDIC, "The Economic Impact of Illicit Drug Use on American Society" (Washington D.C.: National Drug Intelligence Center - U.S. Department of Justice, 2011), http://www.justice.gov/archive/ndic/pubs44/44731/ 44731p.pdf.

${ }^{68} \mathrm{http}: / /$ www.emcdda.europa.eu/.

${ }^{69}$ EMCDDA, Towards a better understanding of drug-related public expenditure in Europe, (Lisbon, 2008).

${ }^{70}$ For more information on drug-related public expenditure please refer to EMCDDA.
} 
Figure 18. Drug-related public expenditure as a share of GDP and total gross profit as share of GDP, selected Balkan route countries, various years

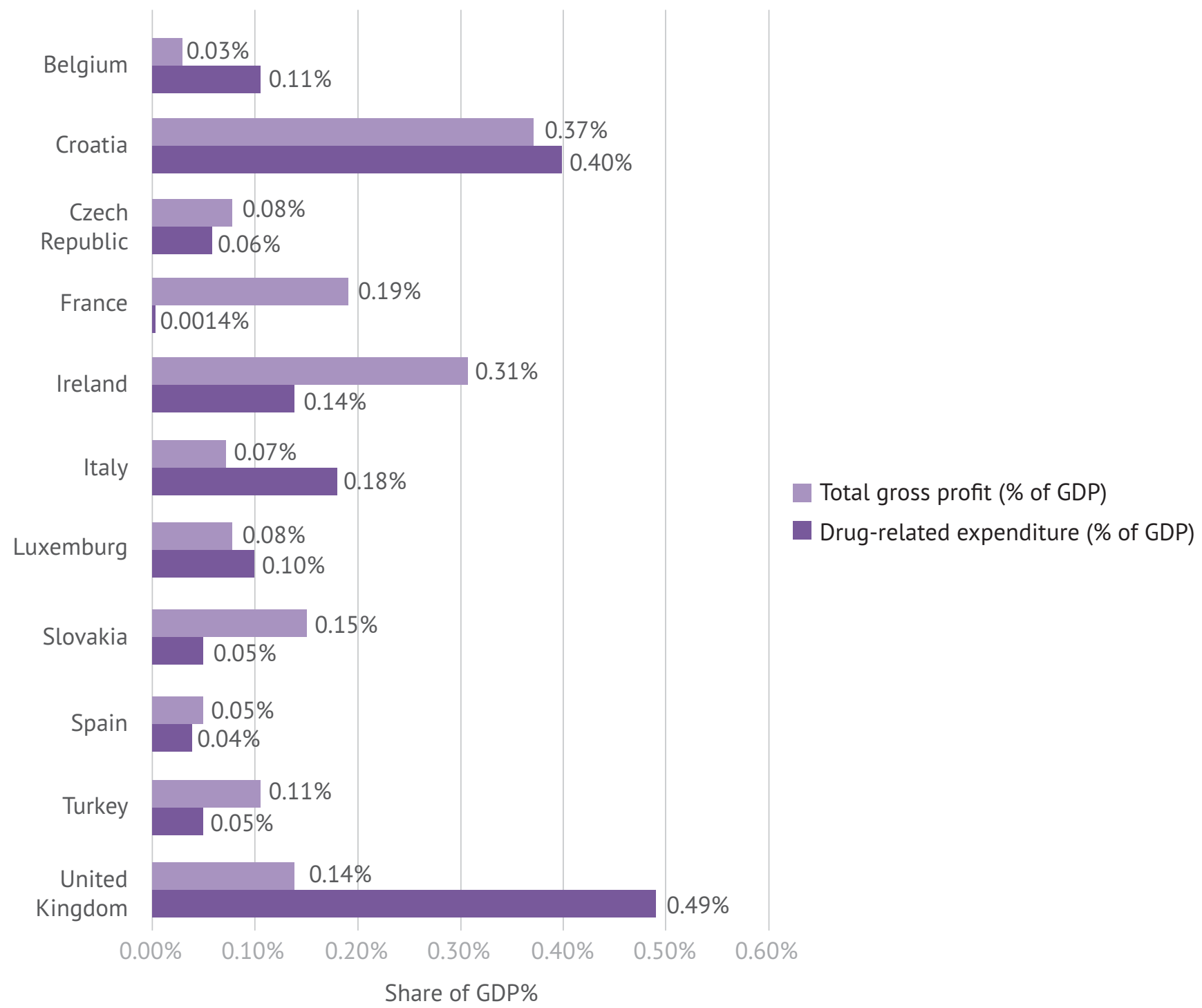

Source: $E M C D D A$.

\section{Box 7. Where do criminals reinvest their illicit proceeds?}

Study of the reinvestment of illicit proceeds is difficult, and it becomes even more complicated when it is associated with a transnational crime like opiate trafficking. However, some studies have shown that criminals active in Europe reinvest the proceeds either in the legal economy or in further criminal activities. ${ }^{71}$ Although firm conclusions cannot be drawn, based on those studies it can be assumed that the traffickers of illicit Afghan opiates on the Balkan route also behave in that manner.

The main purposes of investing in the legal economy are to conceal the illicit nature of profits and to legitimate wealth. An ancillary driver of investment in the legal economy is its safer nature compared with investment in other criminal activities. Money laundering is difficult to investigate, so the risk of apprehension by law enforcement agencies is low. ${ }^{72}$

\footnotetext{
${ }^{71}$ Ernesto U. Savona and Michele Riccardi, "From Illegal Markets to Legitimate Businesses: The Portfolio of Organised Crime in Europe" (Milan-Trento: co-funded by EU Commission, DG Home Affairs. Transcrime, Università Cattolica del Sacro Cuore and Università degli Studi di Trento, 2015).

${ }^{72}$ Ibid.
} 
As in the case of other types of transnational organized crime, the proceeds from opiate trafficking may finance other drug shipments or other criminal activities. Investments in further opiate shipments and, to a lesser extent, in the group's operational expenses may account for a considerable proportion of traffickers' outflows since the illicit opiate trade needs considerable cash flows. Besides the money invested in purchasing illicit opiates, criminals have various other costs, such as transport/shipping costs or bribes to corrupt customs officials.

\section{What methods do criminals use to launder their proceeds?}

To explore how the proceeds from illicit opiates are reinvested, key information was gathered during the Conference on Illicit Financial Flows. ${ }^{73}$ Twenty-one experts, representing nine countries among the SELEC members and the Islamic Republic of Iran, participated in a survey. Although anecdotal, responses to the survey show that the money-laundering methods exploited by opiate traffickers on the Balkan route are similar to those used in most other European countries. ${ }^{74}$ Cash-based methods are the most widespread money laundering schemes employed. The reason for resorting to cash smuggling is the low risk of detection by law enforcement agencies. Moreover, cash smuggling requires a low level of sophistication and organization.

Besides cash smuggling, the use of "straw men" (fake figureheads) and structuring or "smurfing" (making cash deposits below the reporting threshold) are the mechanisms most likely to be employed by criminals to hide the illicit origin of their proceeds. All these methods require few skills and a little sophistication, and they can therefore be easily carried out by criminals and their accomplices. ${ }^{75}$ "Chinese box" schemes (legal entities organized into complex ownership schemes) and intermediaries, however, require more professionalism. Likewise, Informal Value Transfer Systems, the exploitation of tax havens, and electronic funds transfers seem to be less widespread because they require the involvement of expert professionals. ${ }^{76}$

In what legitimate industries do criminal groups invest?

Criminals may invest in a variety of legitimate industries. ${ }^{77}$ Scientific literature has considered real estate to be the most likely investment by criminals trafficking illicit opiates. The real estate sector lacks a supervisory institution able to determine the lawfulness of transactions and to impose sanctions in the case of misconduct. ${ }^{78}$ Moreover, the value of properties is difficult to evaluate objectively, and the market often consists of a closed network. ${ }^{79}$ Furthermore, in some countries, the real estate sector does not require the performance of any customer due diligence. ${ }^{80}$ These factors make speculation common in this sector, with a low risk of intervention by law enforcement agencies. ${ }^{81}$ Criminals can also exploit properties as operational and logistical bases for drug trafficking, gambling or sexual exploitation.

The investment decision-making process shares some features with the selection of the preferred moneylaundering system. Experts state that criminals are more prone to invest in sectors which are low-tech, cashand labour-intensive. For these reasons, coffee bars, restaurants, pubs, nightclubs, as well as casinos and betting

\footnotetext{
${ }^{73}$ The Southeast European Law Enforcement Center (SELEC) and UNODC jointly organized the conference on illicit financial flows. The conference took place on the 27th - 28th of November 2014 in Bucharest, at SELEC Headquarters. For more information: http://www.selec. org/p590/02+December+2014.

${ }^{74}$ Ernesto U. Savona and Michele Riccardi, "From Illegal Markets to Legitimate Businesses: The Portfolio of Organised Crime in Europe.," Final Report of Project OCP - Organised Crime Portfolio (Trento: Transcrime - Università degli Studi di Trento, 2015).

${ }^{75}$ Ibid.

${ }^{76}$ Ibid.

${ }^{77}$ Investments in the legal economy may roughly correspond to the integration stage of the money-laundering process. However, the layering and integration stages may sometimes overlap, and some of these investments may also hide the illicit origin of criminal proceeds.

${ }^{78}$ Hans Nelen, "Real Estate and Serious Forms of Crime," International Journal of Social Economics 35, no. 10 (August 29, 2008): 751-62.

${ }^{79}$ Ibid.; Louise Shelley, "Money Laundering into Real Estate," INSIDE TraCCC Issue 2, Terrorism, Transnational Crime and Corruption Center (TraCCC) (Terrorism, Transnational Crime and Corruption Center, 2013), http://traccc.gmu.edu/insidetraccc-issue-2/\#8.

${ }^{80}$ FATF, International Standards on Combating Money Laundering and the Financing of Terrorism \& Proliferation. The FATF Recommendations (Paris: OECD, 2012), http://www.fatf-gafi.org/media/fatf/documents/recommendations/pdfs/FATF_Recommendations.pdf.

${ }^{81}$ Nelen, "Real Estate and Serious Forms of Crime"; Brigitte Unger et al., "Detecting Criminal Investment in the Dutch Real Estate Sector" (Dutch Ministry of Finance, Justice and Interior Affairs, 2010).
} 
venues, are widely used. They can also be exploited as fronts for criminal activities: to store illicit drugs, for example, but also for prostitution or forced labour. ${ }^{82}$

The survey also revealed that transport and the renting of motor vehicles are among the main sectors in which drug traffickers invest. By transporting legal goods or travellers, traffickers may more easily smuggle large quantities of drugs. Investments by criminals in bonds, stocks, options, futures, etc. do not emerge from the survey. Investments in these financial instruments require technical expertise that criminals may not possess, or the hiring of external professionals whom criminals may not trust. ${ }^{.3}$

${ }^{82}$ Savona and Riccardi, "From Illegal Markets to Legitimate Businesses: The Portfolio of Organised Crime in Europe." ${ }^{83}$ Ibid. 


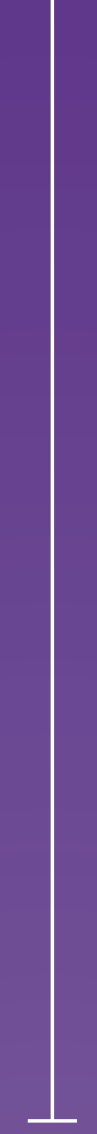

Annex 



\section{Annex 1. Estimating the gross profit made from the trafficking of illicit opiates on the Balkan route}

This study estimates the monetary value of illicit opiates trafficked on the Balkan route (value added), in terms of the gross profit made by traffickers. The gross profit is the amount of money earned from the trafficking of illicit opiates and includes turnover from international trade, wholesale distribution and retail sales of illicit opiates minus the costs necessary to buy and/or produce them.

The procedure to estimate the gross profit generated on the Balkan route moves through three steps:

- The first step estimates the total quantity of opiates trafficked on the Balkan route (see Annex.1.1).

- The second step assesses the flow of opiates trafficked on the Balkan route (see Annex.1.2).

- The third step combines the volume traded with prices and costs, thereby estimating the gross profit at the country level (see Annex.1.3). ${ }^{84}$

The study estimates gross profit in GDP-like terms to allow for comparisons with the available estimates of the legitimate economy of the Balkan route countries (see Annex 2). ${ }^{85}$

\section{Annex.1.1. The total quantity of opiates trafficked on the Balkan route - Step 1}

Estimating the total quantity of illicit opiates traded along the Balkan route is the first step in calculating the gross profit made by traffickers. The study adopts a demand-based approach to perform this estimate, which assumes that the total quantity of illicit opiates entering the countries on the route is equal to the sum of the consumption and seizures of illicit opiates in the Balkan route countries. ${ }^{86,87}$

Losses $^{88}$ and stockpiles are other components of the quantity of illicit opiates flowing along the route. ${ }^{89}$ The lack of data concerning these elements prevents their estimation.

The following sub-sections describe the estimates of consumption (see Annex 1.1.1) and seizures (see Annex 1.1.2).

\footnotetext{
${ }^{84}$ The figures presented in this study are based on 2009-2012 data (averages). Quantities of opiates (heroin/morphine and opium) are expressed in terms of pure heroin equivalents in order to enable comparison of volumes among countries, different substances, and different stages of the supply chain. Afghan estimates are presented separately from the estimates for the Balkan route countries because Afghanistan is not only the source of the illicit opiates flowing into the Balkan route but also supplies other markets through various routes.

${ }^{85}$ Letizia Paoli, Victoria A. Greenfield, and Peter Reuter, The World Heroin Market: Can Supply Be Cut? (Oxford University Press, 2009); OECD, Measuring the Non-Observed Economy. A Handbook (Paris: OECD, 2002), http://www.oecd.org/dataoecd/9/20/1963116.pdf.

${ }^{86}$ The estimate of the quantities of illicit opiates is restricted to heroin, morphine, and raw opium, which account for most of the worldwide opiate consumption. While opiates may encompass many other opium-derivate products, their consumption seems to be limited to few user groups. Moreover, the limited availability of data and information on other opium-derivate products does not allow for meaningful quantification of these substances.

${ }^{87}$ Paoli, Greenfield, and Reuter, The World Heroin Market.

${ }^{88}$ A certain quantity of opiates may be lost during their trafficking. However, given the high price of illicit opiates, it is supposed that traffickers as final consumers take particular care in the management of drugs, so that losses are only a middling share of the total amount of illicit opiates circulating. Therefore, final estimates suffer from a minor bias even if the model does not estimate losses.

${ }^{89}$ Ibid.; UNODC, The Global Afghan Opium Trade (Vienna, 2011), http://www.unodc.org/documents/data-and-analysis/Studies/Global_ Afghan_Opium_Trade_2011-web.pdf.
} 


\section{Box A 8. Demand-side estimates}

There are two methods to estimate the quantity of available drugs in a market: the supply-side and demandside approaches.

- Supply-based approaches estimate the area under opium poppy cultivation, and then quantify the drug available in the market considering production per hectare, eradication, yields, import/export, etc. ${ }^{90}$

- Demand-based approaches are based on estimation of the number of drug users and their annual consumption of drugs. ${ }^{91}$

This study adopts the mostly widely used demand-side approach. Despite having the great advantage of allowing for country-specific estimates, demand-based approaches suffer from several limitations related to the estimation of both the prevalence and per-user consumption (see Box A 9 and Box A 10). ${ }^{92}$

\subsubsection{Estimating the consumption of opiates}

The study calculates the national consumption $\left(C_{i}\right)$ of illicit opiates by multiplying the national number of opiate users $\left(U_{j}\right)$ by per-user annual consumption $(A C)\left[C_{i}=U_{i} \cdot A C\right]$. The formula expands to consider both the consumption of refined (heroin, $H e)$ and un-refined products (opium, $O p)\left[C_{i}=\left(U_{i H e} \cdot A C_{H e}\right)+\left(U_{i O p} \cdot A C_{O p}\right)\right]($ see $T a b l e$ A 6 and Box A 10).

The country-specific number of illicit opiate users $\left(U_{i}\right)$ is the product of the most recent data available on prevalence of opiate abuse $\left(\operatorname{Prev}_{i}\right)^{93}$ and the national adult population in the same year $\left(\operatorname{Pop}_{i}\right)\left[U_{i}=\operatorname{Prev}_{i} \cdot \operatorname{Pop}_{i}\right]{ }^{94}$ Information on the per-user annual consumption comes from a meta-analysis of estimates available in the literature $^{95}$ (see Table A 5 and Box A 9).

\section{Box A 9. Methods for estimating the prevalence of opiate use}

The main methods used to estimate the prevalence of drug use are a) general household surveys and b) indirect estimation. ${ }^{96}$ Since certain countries along the Balkan route adopt the former method and other countries the latter, this study relies on both to produce estimates of drug users at country level.

a) General household surveys are the standard method used to collect information on drug users. They are able to produce country-specific estimates for a large number of countries. Nevertheless, they are difficult to compare due to the differences in the collection/analysis of data conducted by different countries. ${ }^{97}$ Moreover, they fail fully to estimate the number of the most problematic drug users, such as heroin users. This is due to three main factors:

- Problematic drug use is uncommon; few people are heavy drugs consumers.

- Highly addictive drugs, such as heroin, are more likely to be unreported compared with other types of drugs, such as cannabis. People are not willing to report their addiction because of the stigma associated with such consumption.

\footnotetext{
${ }^{90}$ UNODC and Islamic Republic of Afghanistan Ministry of Counter-Narcotics, Afghan Opium Survey 2014 (Vienna, 2014), http://www.unodc. org/documents/crop-monitoring/Afghanistan/Afghan-opium-survey-2014.pdf.

${ }^{91}$ Beau Kilmer et al., "Bringing Perspective to Illicit Markets: Estimating the Size of the U.S. Marijuana Market," Drug and Alcohol Dependence 119, no. 1-2 (2011): 153-60.

${ }^{92}$ Matthew Hickman and C. Taylor, "Estimating the Prevalence of Problematic Drug Use: A Review of Methods and Their Application," Offprint from Bulletin on Narcotics LIV, no. 1 and 2 (2002).

${ }^{93}$ Information on the prevalence of illicit opiate use is taken from UNODC and the European Monitoring Centre on Drug and Addiction (EMCDDA). In particular, for Kosovo and Montenegro, the data are from EMCDDA. Data on prevalence refer to the share of opiate users (in terms of adults between the ages of 15 and 64), unless stated otherwise.

${ }^{94}$ Paoli, Greenfield, and Reuter, The World Heroin Market, 96.

${ }^{95}$ Grossop et. al 1997, Institut für Suchtforschung, Universität Zürich, Institut fur Sozial and Praventivmedizin 1997, UNODC 2005, Eisenbach Stangl 2007, EMCDDA 2008, Paoli et al. 2009, Kilmer et al. 2011, Eisenbach Stangl and Rodriguez 2012 report the 29 estimates included in the analysis.

${ }^{96}$ Hickman and Taylor, "Estimating the Prevalence of Problematic Drug Use: A Review of Methods and Their Application."

${ }^{97}$ Ibid.
} 
- Household surveys tend to overlook people who are in treatment, incarcerated or in remote geographical areas. $^{98}$

b) Indirect estimation methods (capture-recapture methods, multiplier methods, event-based multipliers, Truncated Poisson, etc.) concentrate on problematic drug use and socially stigmatized behaviours. Starting with a sample of drug users, the indirect methods identify the proportion of the targeted population with problematic use in the general population. ${ }^{99}$ These data collection techniques are able to remedy the main shortcomings stemming from the use of household surveys.

Table A 5. Prevalence and number of illicit opiate users in the Balkan route countries/territory (percentage and number of units), latest available year

\begin{tabular}{|c|c|c|c|c|c|}
\hline & $\begin{array}{l}\text { Prevalence } \\
\text { considered }\end{array}$ & Year & Age group & $\begin{array}{l}\text { Population } \\
\text { considered }\end{array}$ & $\begin{array}{l}\text { Number of } \\
\text { opiate users }\end{array}$ \\
\hline Albania & $0.45 \%$ & 2007 & $15-64$ & $2,102,268$ & 9,460 \\
\hline Austria & $0.45 \%$ & 2012 & $15-64$ & $5,696,435$ & 25,634 \\
\hline Belgium & $0.20 \%$ & 2008 & $15-64$ & $7,074,056$ & 14,148 \\
\hline Bosnia and Herzegovina & $0.30 \%$ & 2009 & $15-64$ & $2,710,127$ & 8,130 \\
\hline Bulgaria & $0.51 \%$ & 2011 & $15-64$ & $5,000,019$ & 25,500 \\
\hline Croatia & $0.36 \%$ & 2010 & $15-64$ & $2,874,432$ & 10,348 \\
\hline Czech Republic & $0.15 \%$ & 2012 & $15-64$ & $7,225,490$ & 10,838 \\
\hline Denmark & $0.52 \%$ & 2009 & $15-64$ & $3,629,215$ & 18,872 \\
\hline France & $0.49 \%$ & 2011 & $15-64$ & $42,004,546$ & 205,822 \\
\hline Germany & $0.40 \%$ & 2012 & $18-64$ & $54,205,885$ & 216,824 \\
\hline Greece & $0.29 \%$ & 2012 & $15-64$ & $7,258,246$ & 21,049 \\
\hline Hungary & $0.05 \%$ & 2011 & $15-64$ & $6,836,549$ & 3,418 \\
\hline Iran (Islamic Republic of) & $2.27 \%$ & 2010 & $15-64$ & $53,034,971$ & $1,203,894$ \\
\hline Ireland & $0.72 \%$ & 2006 & $15-64$ & $2,938,179$ & 21,155 \\
\hline Italy & $0.45 \%$ & 2012 & $15-64$ & $38,697,614$ & 174,139 \\
\hline Kosovo & $0.40 \%$ & 2010 & $15-64$ & $1,169,789$ & 4,679 \\
\hline Luxembourg & $0.59 \%$ & 2007 & $15-64$ & 325,186 & 1,919 \\
\hline fYR of Macedonia & $0.50 \%$ & 2011 & $15-64$ & $1,459,760$ & 7,299 \\
\hline Montenegro & $0.36 \%$ & 2006 & $15-64$ & 419,770 & 1,511 \\
\hline Netherlands & $0.13 \%$ & 2012 & $15-64$ & $11,097,314$ & 14,427 \\
\hline Norway & $0.30 \%$ & 2008 & $15-64$ & $3,159,355$ & 9,478 \\
\hline Poland & $0.10 \%$ & 2012 & $15-64$ & $27,321,714$ & 27,322 \\
\hline Portugal & $0.29 \%$ & 2012 & $15-64$ & $6,933,167$ & 20,106 \\
\hline
\end{tabular}

\footnotetext{
${ }^{98}$ Ibid.
}

${ }^{99}$ Ibid. 


\begin{tabular}{l|rrrrr}
\hline Romania & $0.11 \%$ & 2011 & $15-64$ & $13,818,150$ & 15,200 \\
\hline Serbia & $0.28 \%$ & 2011 & $18-64$ & $4,944,362$ & 13,844 \\
\hline Slovakia & $0.13 \%$ & 2008 & $15-64$ & $3,877,310$ & 5,041 \\
\hline Slovenia & $0.44 \%$ & 2011 & $15-64$ & $1,418,370$ & 6,241 \\
\hline Spain & $0.23 \%$ & 2013 & $15-64$ & $31,180,585$ & 71,715 \\
\hline Sweden & $0.23 \%$ & 2010 & $15-64$ & $6,106,914$ & 14,046 \\
\hline Switzerland & $0.53 \%$ & 2013 & $15-64$ & $5,460,913$ & 28,943 \\
\hline Turkey & $0.03 \%$ & 2011 & $15-64$ & $49,931,824$ & 14,980 \\
\hline United Kingdom & $0.81 \%$ & 2011 & $15-64$ & $41,628,975$ & 337,195 \\
\hline Afghanistan & $2.65 \%$ & 2009 & $15-64$ & $10,094,000$ & 267,491 \\
\hline
\end{tabular}

Note: information on the prevalence of illicit opiate use is from UNODC and EMCDDA. The data for Kosovo and Montenegro, in particular, are from EMCDDA. Population data retrieved from United Nations Department of Economic and Social Affairs, Population Division (2015). The number of consumers multiplied by the per-user annual consumption gives the consumed volume (see Box $A 10$ and Table $A$ 6) $\left[C_{i}=U_{i} \cdot A C\right]$.

Source: elaboration on UNODC and EMCDDA data.

\section{Box A 10. Estimating per-user consumption}

Little is known about the typical quantities of a drug consumed by a drug user. ${ }^{100}$ The lack of good estimates of the quantities of drugs consumed by opiate users may profoundly affect the quality of the estimates and of the analysis of drug markets. The difficulties in developing consumption estimates are related to the fact that users cannot precisely report how much of an illegal drug they purchase; nor can they state its quality. Consequently, too few data are available to permit country-specific estimates of the average consumption for most of the countries included in this study.

This study assumes as a best estimate that heroin users consume 44.0 pure grams of heroin per year. This value is the average of 29 different estimates of the per-user annual consumption. ${ }^{101}$ The studies included in this meta-analysis based their estimates on surveys, on theoretical assumptions, and on experiments. ${ }^{102}$ Studies have been selected according to the soundness of their methodology, as well as a geographic criterion so as to include as many Balkan route countries as possible. To cope with uncertainties, such as the significant variation of the estimates or the fact that per-user consumption may vary over time and across countries, the study adopts a low and high estimate based on the standard deviation of the distribution of the available analysis. The low and the high estimate assume an annual consumption of 35.0 and 54.0 grams of pure heroin per user. For unrefined opiate products, the study considers an annual per user consumption of 757 grams of opium, which is equal to the consumption of 3 grams per 252 days a year. ${ }^{103}$

\footnotetext{
${ }^{100}$ Kilmer and Pacula, "Estimating the Size of the Illegal Drug Market: A Demand-Side Approach."

${ }^{101}$ Gossop et al. (1997), Uchtenhagen et al. (1997), UNODC (2005), Eisenbach Stangl (2007), EMCDDA (2008), Paoli et al. (2009), Kilmer et al. (2011), Eisenbach Stangl and Rodriguez (2012) collect all these studies.

${ }^{102}$ Michael Gossop et al., "The National Treatment Outcome Research Study in the United Kingdom: Six-Month Follow-up Outcomes.," Psychology of Addictive Behaviors 11, no. 4 (1997): 324-37; UNODC, "The Eighth United Nations Survey on Crime Trends and the Operations of Criminal Justice Systems (2001 - 2002)" (UNODC, 2005), http://www.unodc.org/unodc/en/data-and-analysis/Eighth-UnitedNations-Survey-on-Crime-Trends-and-the-Operations-of-Criminal-Justice-Systems.html; Ambros Uchtenhagen, Felix Gutzwiller, and Anja Dobler-Mikola, Versuche Für Eine Ärztliche Verschreibung von Betäubungsmitteln. Zweiter Zwischenbericht Der Forschungsbeauftragten (Zürich: Institut für Suchtforschung in Verbindung mit der Universität Zürich : Institut für Sozial- und Präventionsmedizin der Universität Zürich, 1997); Irmgard Eisenbach Stangl, "First Multi-City Study on Quantities and Financing of Illicit Drug Consumption - QUAF1" (Vienna: European Centre for Social Welfare Policy and Research affiliated to the United Nations, 2007); EMCDDA, "Statistical Bulletin 2008," EMCDDA, 2008, http://www.emcdda.europa.eu/stats08; Paoli, Greenfield, and Reuter, The World Heroin Market; Kilmer et al., "Bringing Perspective to Illicit Markets"; Irmgard Eisenbach Stangl and Ricardo Rodigues, "Second Multi-City Study on Quantities and Financing of Illicit Drug Consumption" (Vienna: European Centre for Social Welfare Policy and Research affiliated to the United Nations, 2012).

${ }^{103}$ UNODC and Islamic Republic of Afghanistan - Ministry of Counter Narcotics, Afghanistan Opium Survey 2009 (Vienna, 2009), http:// www.unodc.org/documents/crop-monitoring/Afghanistan/Afghan_report_Summary_Findings_2013.pdf.
} 
Table A 6. Heroin and opium consumption in the Balkan route countries/territory (kilograms of pure illicit opiates), 2009-2012 average

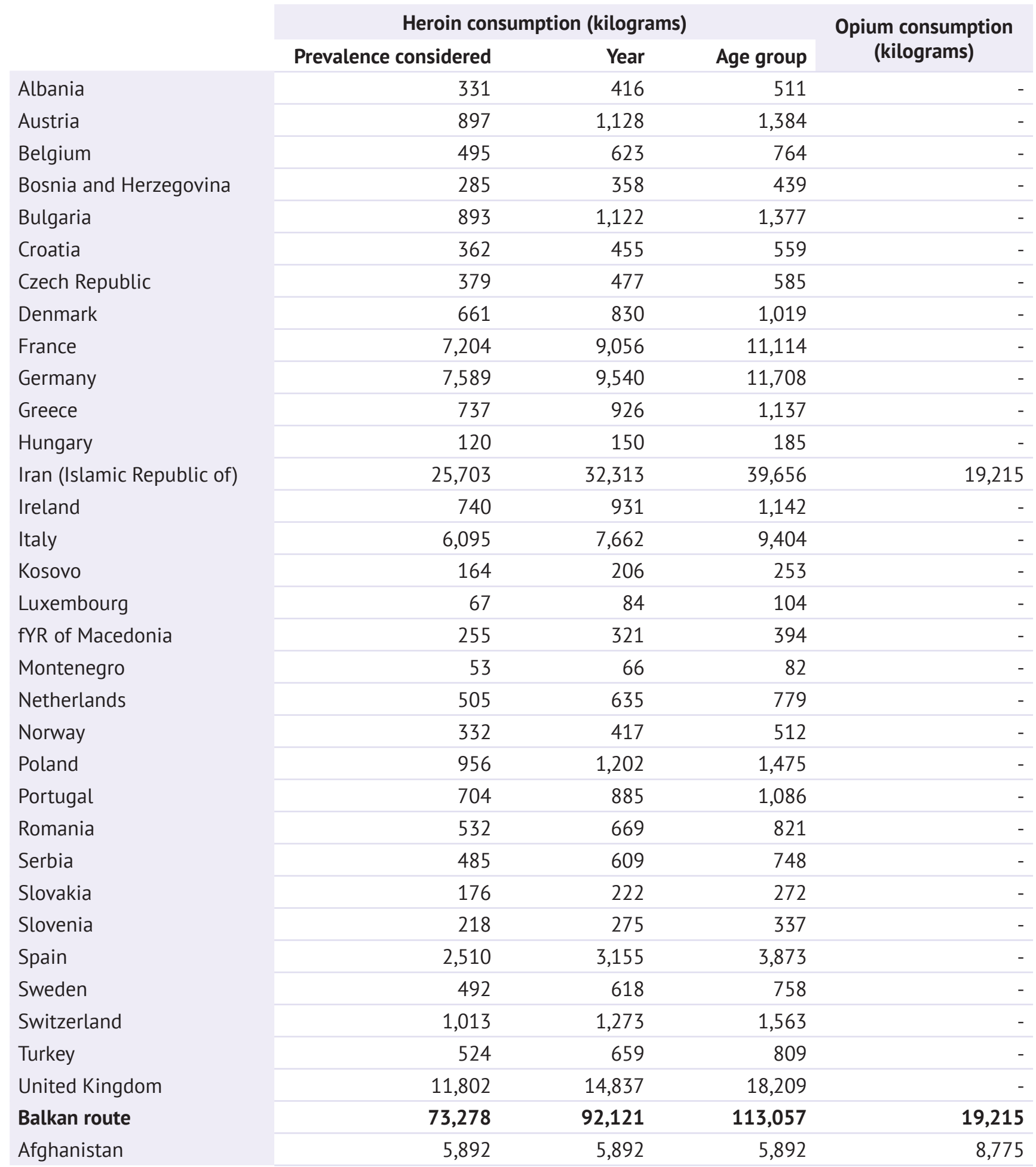

Note: different assumptions on per-user annual consumption of illicit opiates determine the three estimates (see Box A 10). Afghan consumption relies on information from the Afghan Opium Surveys, which do not provide multiple estimates. ${ }^{104}$ The consumed volume is given by the number of consumers (see Table A 5) multiplied by the per-user annual consumption (see Box $A$ 10) $\left[C_{i}=U_{i} \cdot A C\right.$.

Source: elaboration on UNODC and EMCDDA data.

\footnotetext{
${ }^{104}$ Ibid.; UNODC and Islamic Republic of Afghanistan - Ministry of Counter Narcotics, Afghanistan Opium Survey (Vienna, 2010, 2011, 2012).
} 


\subsubsection{Estimating seizures of illicit opiates}

This study estimates purity-adjusted seizures for every Balkan route country in order to compare them across countries and to sum them with consumption, which is expressed in terms of pure substance.

Data on seizures are from UNODC, which provides non purity-adjusted seizure data for every Balkan route country. ${ }^{105}$ The purity of heroin differs according to the stage of the supply chain that it has reached. In particular, purity tends to decrease the closer heroin is to final consumers because of cutting. ${ }^{106}$ The study estimates pure seizures by subdividing total heroin seizures into three levels representing the stages of the supply chain and then correcting non purity-adjusted seizures for the estimated purity of the specific stage of the supply chain (see Annex 3 for the estimate of purity levels).

Information on the stage of the supply chain at which the seizures have occurred is not available in the UNODC database, and not all countries report all the seizures they perform, thus impeding inference of the stage of the supply chain at which seizures occurred from the size of the seizure itself.

Only one complete analysis of the distribution of seizures in a country along the Balkan route was found in the literature. The study focuses on Italian seizures and makes it possible to make up for this lack of information. ${ }^{107}$ The study takes the amount of Italian seizures as the indicator of the stage of the supply chain at which they occurred (retail - below 1 kilogram, wholesale - between 1 kilogram and 10 kilograms, international trade - above 10 kilograms). It then estimates the relative weights of the three stages of the supply chain (see Table A 7).

The use of data from a single country to obtain cross-country estimates may introduce some biases. To reduce this bias, the weight of the Italian levels is adjusted country by country according to the relative amount of consumed and exported/imported volumes in each country with respect to Italy. This correction determines an increase in the weight of seizures at international trade whenever the amount of international trade in a given country is higher than in Italy, and a decrease whenever wholesale or retail seizures are relatively larger than in Italy.

Table A 7. Distribution of seizures according to the Italian level of seizures (percentages), 2000-2007 average

\begin{tabular}{|c|c|c|c|c|}
\hline $\begin{array}{l}\text { Seizures by size } \\
\text { (grams) }\end{array}$ & $\begin{array}{l}\text { Share of total } \\
\text { (percentage) }\end{array}$ & $\begin{array}{c}\text { Cumulative } \\
\text { (percentage) }\end{array}$ & Supply chain stage & $\begin{array}{l}\text { Seizures per level } \\
\text { (percentage) }\end{array}$ \\
\hline $0.1-1$ & $0.0 \%$ & $0.0 \%$ & \multirow[t]{9}{*}{ Retail } & \multirow[t]{9}{*}{$7 \%$} \\
\hline $1.1-5$ & $0.1 \%$ & $0.1 \%$ & & \\
\hline $5.1-10$ & $0.1 \%$ & $0.2 \%$ & & \\
\hline $10.1-20$ & $0.2 \%$ & $0.3 \%$ & & \\
\hline $20.1-30$ & $0.1 \%$ & $0.5 \%$ & & \\
\hline $30.1-40$ & $0.1 \%$ & $0.6 \%$ & & \\
\hline $40.1-50$ & $0.1 \%$ & $0.7 \%$ & & \\
\hline $50.1-100$ & $0.5 \%$ & $1.2 \%$ & & \\
\hline 100.1. - 1,000 & $5.9 \%$ & $7.1 \%$ & & \\
\hline $1,000.1-10,000$ & $22.1 \%$ & $29.1 \%$ & Wholesale & $22 \%$ \\
\hline $10,000.1-50,000$ & $30.7 \%$ & $59.9 \%$ & \multirow[t]{2}{*}{ International trade } & \multirow[t]{2}{*}{$71 \%$} \\
\hline$>50,000$ & $40.1 \%$ & $100.0 \%$ & & \\
\hline Total & $100.0 \%$ & & & $100 \%$ \\
\hline
\end{tabular}

Note: the study takes and adjusts the weight ranges developed by EMCDDA. ${ }^{108}$ The defined ranges are intended to accommodate the characteristics of different national drug markets. These weight ranges are: 0.0 kilogram-1.0 kilogram, between 1.0 kilogram and 10 kilograms, and above 10 kilograms. This study substitutes the 1.5 kilogram threshold with a 1.0 kilogram threshold to make it compatible with the categories of the only study reporting complete seizure data. The study merges the two categories above 10 kilograms defined by EMCCDA.

Source: elaboration on Rossi and Ricci data. ${ }^{109}$

\footnotetext{
${ }^{105}$ UNODC, World Drug Report (Vienna, 2015).

${ }^{106}$ Jonathan Caulkins, "Price and Purity Analysis for Illicit Drug: Data and Conceptual Issues," Heinz Research, May 24, 2005, http:/ / repository. cmu.edu/heinzworks/25.

${ }^{107}$ Carla Rossi and Roberto Ricci, "Modelling and Estimating Illicit Drug Market as a Tool to Evaluate Drug Policy: The Case of Italy" (Rome: University of Rome Tor Vergata, 2009); http://www.issdp.org/conferences/2009/papers/Rossi_REVISED_Modelling\&estimating_ illicitdrugmarket.pdf.

${ }^{108}$ EMCDDA, Pilot Study on Wholesale Drug Prices in Europe (Lisbon, 2011).

109 Carla Rossi and Roberto Ricci, "Modelling and Estimating Illicit Drug Market as a Tool to Evaluate Drug Policy: The Case of Italy" (Rome: University of Rome Tor Vergata, 2009).
} 
This study considers morphine volumes equivalent to volumes of heroin. Opium seizures are converted into pure heroin equivalent in order to sum them with seizures of other illicit opiates. The study adopts the conversion factor of the Afghanistan Opium Survey 2014, which indicates that 18.5 units of opium are needed to produce a single unit of pure heroin equivalent. ${ }^{110}$

After estimating the weight of the three levels of seizures $\left(d_{i l}\right)$, it is possible to adjust seizure data $\left(S_{n p_{i}}\right)$ for purity levels $\left(p_{i l}\right)$ and to sum them with purity-adjusted seizures of opium $\left(S_{O i}\right)\left[S_{P i}=\left[\sum_{l=1}^{3}\left(S_{n P i} \cdot d_{i l} \cdot p_{i l}\right)\right]+S_{O i} ; \sum_{l=1}^{3} d_{i l}=1\right]$ (see Table A 8).

\section{Box A 11. The estimate of purity levels of seizures}

To adjust country-specific seizures for purity, volumes of seizures are divided into three levels representing the three stages of the opiate trafficking supply chain (international trade, wholesale, retail). The study estimates the purity at each stage $\left(p_{i l}\right)$.

With respect to the average values of Table A 22 in Annex 3:

- Purity at international trade $\left(p_{i t r}\right)$ is the average of typical $\left(T_{\text {wS. pu }}\right)$ and maximum $\left(M_{\text {ws.pu }}\right)$ purity at wholesale level $\left[p_{i t r}=\left(\overline{T_{i w s, p u} ; M_{i \text { ws_pu }}}\right)\right]$

- Purity at wholesale $\left(p_{i \text { wh }}\right)$ is the average of typical $\left(T_{\text {ws.pu }}\right)$ purity at wholesale level and maximum

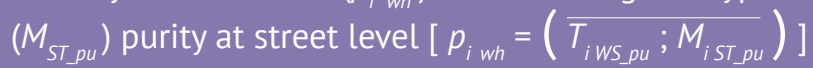

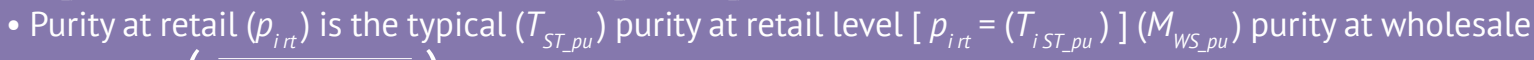
level $\left[p_{i l s}=\left(\overline{T_{i w s . p u} ; M_{i w s . p u}}\right)\right]$

${ }^{110}$ UNODC and Islamic Republic of Afghanistan Ministry of Counter-Narcotics, Afghan Opium Survey 2014 (Vienna, 2014). 
Table A 8. Seizures of opiates in the Balkan route countries/territory (kilograms of pure heroin equivalent), 2009-2012 average

\begin{tabular}{|c|c|c|c|c|c|}
\hline & \multicolumn{3}{|c|}{ Heroin } & \multirow{2}{*}{ Opium } & \multirow{2}{*}{ Total } \\
\hline & Retail & Wholesale & International trade & & \\
\hline Albania & 0.01 & 0.08 & 24.28 & - & 24.37 \\
\hline Austria & 0.19 & 2.89 & 46.33 & 11.03 & 60.45 \\
\hline Belgium & 0.37 & 3.10 & 126.94 & 0.33 & 130.74 \\
\hline Bosnia and Herzegovina & 0.04 & 0.23 & 7.48 & - & 7.75 \\
\hline Bulgaria & 0.16 & 1.75 & 261.25 & 0.42 & 263.57 \\
\hline Croatia & 0.12 & 0.81 & 17.96 & - & 18.89 \\
\hline Czech Republic & 0.06 & 0.43 & 7.57 & - & 8.06 \\
\hline Denmark & 0.16 & 1.40 & 18.21 & 0.08 & 19.85 \\
\hline France & 2.07 & 20.47 & 294.46 & 0.34 & 317.34 \\
\hline Germany & 1.91 & 18.79 & 247.23 & 4.12 & 272.04 \\
\hline Greece & 1.34 & 16.90 & 235.69 & 0.21 & 254.14 \\
\hline Hungary & 0.12 & 0.60 & 19.11 & 0.41 & 20.25 \\
\hline Iran (Islamic Republic of) & 30.20 & 313.49 & $22,879.65$ & $23,524.00$ & $46,747.34$ \\
\hline Ireland & 0.39 & 2.32 & 24.76 & - & 27.47 \\
\hline Italy & 5.08 & 28.04 & 451.27 & 0.39 & 484.77 \\
\hline Kosovo & 0.13 & 0.82 & 24.37 & - & 25.32 \\
\hline Luxembourg & 0.01 & 0.06 & 7.37 & - & 7.44 \\
\hline fYR of Macedonia & 0.08 & 0.60 & 39.00 & - & 39.68 \\
\hline Montenegro & 0.00 & 0.02 & 4.26 & - & 4.28 \\
\hline Netherlands & 0.70 & 3.27 & 340.42 & 20.79 & 365.18 \\
\hline Norway & 0.28 & 3.43 & 35.91 & 0.03 & 39.64 \\
\hline Poland & 0.01 & 0.06 & 10.38 & 2.97 & 13.43 \\
\hline Portugal & 0.48 & 3.00 & 32.33 & 0.00 & 35.81 \\
\hline Romania & 0.63 & 3.26 & 23.37 & 0.18 & 27.45 \\
\hline Serbia & 0.15 & 0.83 & 7.60 & - & 8.58 \\
\hline Slovakia & 0.01 & 0.15 & 1.67 & - & 1.83 \\
\hline Slovenia & 0.02 & 0.11 & 8.78 & 0.02 & 8.92 \\
\hline Spain & 2.15 & 12.03 & 162.71 & 0.05 & 176.94 \\
\hline Sweden & 0.20 & 1.46 & 17.29 & 1.66 & 20.61 \\
\hline Switzerland & 0.82 & 5.71 & 87.38 & 0.19 & 94.10 \\
\hline Turkey & 1.45 & 6.92 & $8,361.77$ & 31.21 & $8,401.35$ \\
\hline United Kingdom & 9.12 & 55.41 & 722.84 & - & 787.37 \\
\hline Balkan route & 58.47 & 508.42 & $34,549.64$ & $23,598.43$ & $58,714.95$ \\
\hline Afghanistan & 29.16 & 204.43 & $25,247.32$ & $3,818.11$ & $29,299.02$ \\
\hline
\end{tabular}

Source: Elaboration on UNODC and Rossi and Ricci data. 


\subsubsection{Estimating the combined quantity of illicit opiates consumed and seized on the Balkan route}

Having estimated the consumption of illicit opiates and the purity-adjusted volume of seizures, it is possible to estimate the country-specific combined quantity of illicit opiates consumed and seized by summing the two elements (see Table A 9). The total combined quantity of illicit opiates consumed and seized determines the quantity of illicit opiates entering the route, and it is the first fundamental step in estimating the gross profit (see Annex.1.1.3).

Table A 9. Combined quantity of illicit opiates consumed and seized in the Balkan route countries/territory (kilograms of pure heroin equivalent), 2009-2012 average

\begin{tabular}{|c|c|c|c|}
\hline & Low estimate & Best estimate & High estimate \\
\hline Albania & 355 & 441 & 535 \\
\hline Austria & 958 & 1,188 & 1,445 \\
\hline Belgium & 626 & 753 & 895 \\
\hline Bosnia and Herzegovina & 292 & 365 & 447 \\
\hline Bulgaria & 1,156 & 1,386 & 1,641 \\
\hline Croatia & 381 & 474 & 578 \\
\hline Czech Republic & 387 & 485 & 593 \\
\hline Denmark & 680 & 850 & 1,039 \\
\hline France & 7,521 & 9,374 & 11,432 \\
\hline Germany & 7,861 & 9,812 & 11,981 \\
\hline Greece & 991 & 1,180 & 1,391 \\
\hline Hungary & 140 & 171 & 205 \\
\hline Iran (Islamic Republic of) & 91,665 & 98,275 & 105,619 \\
\hline Ireland & 768 & 958 & 1,170 \\
\hline Italy & 6,580 & 8,147 & 9,888 \\
\hline Kosovo & 189 & 231 & 278 \\
\hline Luxembourg & 75 & 92 & 111 \\
\hline fYR of Macedonia & 295 & 361 & 434 \\
\hline Montenegro & 57 & 71 & 86 \\
\hline Netherlands & 870 & 1,000 & 1,144 \\
\hline Norway & 371 & 457 & 551 \\
\hline Poland & 970 & 1,216 & 1,489 \\
\hline Portugal & 740 & 920 & 1,122 \\
\hline Romania & 559 & 696 & 848 \\
\hline Serbia & 493 & 618 & 756 \\
\hline Slovakia & 178 & 224 & 274 \\
\hline Slovenia & 227 & 284 & 346 \\
\hline Spain & 2,687 & 3,332 & 4,050 \\
\hline Sweden & 512 & 639 & 779 \\
\hline Switzerland & 1,107 & 1,368 & 1,657 \\
\hline Turkey & 8,926 & 9,060 & 9,210 \\
\hline United Kingdom & 12,589 & 15,624 & 18,996 \\
\hline Balkan route & 151,208 & 170,051 & 190,987 \\
\hline
\end{tabular}

Note: the figures refer to the sum of the consumed and seized volumes. Different assumptions on per-user annual consumption of illicit opiates determine the three estimates (see Box A 10).

Source: elaboration on UNODC. 


\section{Annex.1.2. The country network of illicit opiate trafficking on the Balkan route - Step 2}

The gross profit depends on the differential between the prices of illicit opiates in the country where traffickers purchase them and the country where they sell them. Therefore, the second step in estimating the gross profit is outlining the country network of illicit opiates. This requires:

1. identifying the links among the Balkan route countries (see Annex.1.2.1)

2. estimating the quantity of opiates trafficked through each link (see Annex. 1.2.2).

\subsubsection{Designing the network}

An analysis of seizure cases enables identification of which countries connect with each other in the trafficking network. ${ }^{111}$ Some of the seizure cases recorded by UNODC report information on the producing or manufacturing country, departure or obtained country, and destination country. ${ }^{112}$ This information enables identification of pairs of countries with a mutual relationship. ${ }^{113}$ Trafficking route information contained in the Delta ARQ is a residual source of information allowing detection of links not emerging from the seizure cases analysis. ${ }^{114}$

The volume of seizures $\left(S_{i j}\right)$, indicating a flow of opiates from one country $(j)$ to another $(I)$ is divided by the total volume of seizures ascribed to the importer $\left(\sum_{j=1}^{j} S_{i j}\right)$ to obtain a coefficient of the degree of connection of the two countries $\left(i m p_{i j}\right)\left[i m p_{i j}=S_{i j} / \sum_{j=1}^{j} S_{i j}\right]_{.15}^{115}$ Trafficking route directly provides an estimate of the degree of connection (imp $p_{i j}$ ) for the years 2010-2012. ${ }^{116}$ The study takes an average of the available years.

Whenever the value of the coefficient $\left(i m p_{i j}\right)$ is below the threshold of 4 per cent, the specific link is not considered in the network. ${ }^{117}$ This operation makes it possible to reduce the risk of biases due to the occurrence of large single seizures on relatively small connections.

A check of the links among European countries is conducted using purity-adjusted trade prices (see Annex.4.1). Indeed, in order to have a transaction, the ranges of trade prices observed in the importing and in the exporting country have to present overlaps; if not, the trade cannot occur, so that the link is excluded from the network. Intercontinental connections from Afghanistan, the Islamic Republic of Iran, and non-Balkan route countries to European countries do not undergo this scrutiny, on the assumption that ranges of prices collected within the countries are not suitable for describing these long distance shipments.

\footnotetext{
${ }^{111}$ Rémi Boivin, "Macrosocial Network Analysis: The Case of Transnational Drug Trafficking," in Networks and Network Analysis for Defence and Security, ed. Anthony J. Masys, Lecture Notes in Social Networks (Springer International Publishing, 2014), 49-61, http://link.springer. com/chapter/10.1007/978-3-319-04147-6_3; Siddharth Chandra and Johnathan Joba, "Transnational Cocaine and Heroin Flow Networks in Western Europe: A Comparison,” International Journal of Drug Policy, 2015, doi:10.1016/j.drugpo.2015.04.016.

${ }^{112}$ UNODC, Afghan Opiate Trade Project, and Paris Pact, "Drugs Monitoring Platform," Drugs Monitoring Platform, 2015, http:// drugsmonitoring.unodc-roca.org/; UNODC, "Delta Annual Reports Questionnaire Database" (UNODC, 2014); UNODC, "Individual Drug Seizures," Drugs Monitoring Platform, 2014, https://data.unodc.org/\#state:0.

${ }^{113}$ For example, a seizure case reported by Serbia, which indicates Turkey as Departure or Obtained Country and Austria as Destination Country enables the identification of two links within the network: exporter Turkey/importer Serbia and exporter Serbia/importer Austria. Seizure-Delta ARQ is the primary source of data used to construct the network. Seizure cases in 2007-2012 are considered. The time span of information on seizures is longer than that for other data used in the model because of a shortage of data, which would cause a reduction in the geographical scope of the study. Whenever a country is not included in Seizure-Delta ARQ, but is included in the IDS online database of UNODC, this database becomes the primary source of data for the country. Whenever a country of interest is not included in any of these databases, data on seizures are collected from the Drug Monitoring Platform. All available seizure cases collected from the IDS online database and the Drug Monitoring Platform are included in the analysis regardless of the year of their occurrence.

${ }^{114}$ UNODC, Delta Annual Reports Questionnaire Database, 2014.

115 The importance of each link depends, among other factors, on the amount of opiates seized in one of the two countries participating in the specific trade. Whenever two countries exporting opiates to the same third country have different levels of law enforcement, the relative importance of their exports to the county considered may be biased. In particular, the more seizures that a country makes in comparison with the others, the more its importance in the specifically linked risks is upward biased. Despite this limitation, the method described remains the main one with which to depict the opiate trade network. This is because it is the only method that includes all the Balkan route countries and estimates all the links. Indeed, to avoid this bias, it would be necessary to consider only data from importing or from exporting countries separately. This would require detailed information on seizures in each Balkan route country, which is not available.

${ }^{116}$ Ibid.

${ }^{117}$ This is the case, for example, of the link between Pakistan and the Islamic Republic of Iran.
} 
The study adjusts the connection coefficients to merge the links obtained from the seizure case analysis with the ones from Trafficking route and to match imports and demand when links are deleted [ $i m p_{-} a d_{j i}=i m p_{j i} / \sum_{j=1}^{J} i m p_{j i}$ ] (see Table A 10 for the values of imp_ad $d_{j i}$ ).

The study considers morphine volumes as equivalent to volumes of heroin. Volumes of heroin and morphine are not purity adjusted when used to construct the network. Opium volumes are converted into heroin of Afghan export quality assuming that 9.6 units of opium are needed to produce a single unit of heroin with a purity level of 52 per cent. ${ }^{118}$

Table A 10. The country/territory network of illicit opiate trafficking on the Balkan route (percentages), 2009-2012 average

\begin{tabular}{|c|c|c|}
\hline Exported from & Trafficked to & Share of total import (percentage) \\
\hline Afghanistan & Iran (Islamic Republic of) & $100 \%$ \\
\hline Albania & Greece & $12 \%$ \\
\hline Albania & Italy & $18 \%$ \\
\hline Albania & Montenegro & $36 \%$ \\
\hline Albania & Slovenia & $5 \%$ \\
\hline Austria & Czech Republic & $32 \%$ \\
\hline Austria & Non-Balkan route countries & N.A \\
\hline Austria & Germany & $8 \%$ \\
\hline Austria & Slovakia & $10 \%$ \\
\hline Austria & Switzerland & $23 \%$ \\
\hline Belgium & Non-Balkan route countries & N.A \\
\hline Belgium & France & $15 \%$ \\
\hline Belgium & Ireland & $14 \%$ \\
\hline Belgium & Luxembourg & $91 \%$ \\
\hline Belgium & Spain & $6 \%$ \\
\hline Belgium & Sweden & $14 \%$ \\
\hline Bosnia and Herzegovina & Montenegro & $5 \%$ \\
\hline Bosnia and Herzegovina & Slovenia & $14 \%$ \\
\hline Bulgaria & Albania & $4 \%$ \\
\hline Bulgaria & Austria & $36 \%$ \\
\hline Bulgaria & Belgium & $23 \%$ \\
\hline Bulgaria & Croatia & $83 \%$ \\
\hline Bulgaria & Non-Balkan route countries & N.A \\
\hline Bulgaria & fYR of Macedonia & $40 \%$ \\
\hline Bulgaria & Germany & $13 \%$ \\
\hline Bulgaria & Greece & $7 \%$ \\
\hline Bulgaria & Italy & $15 \%$ \\
\hline Bulgaria & Poland & $18 \%$ \\
\hline Bulgaria & Romania & $88 \%$ \\
\hline Bulgaria & Serbia & $71 \%$ \\
\hline Bulgaria & Sweden & $41 \%$ \\
\hline Bulgaria & Netherlands & $8 \%$ \\
\hline Croatia & Bosnia and Herzegovina & $15 \%$ \\
\hline Croatia & Slovenia & $14 \%$ \\
\hline Czech Republic & Denmark & $11 \%$ \\
\hline
\end{tabular}

\footnotetext{
${ }^{118}$ UNODC and Islamic Republic of Afghanistan Ministry of Counter-Narcotics, Afghan Opium Survey 2014 (Vienna, 2014).
} 


\begin{tabular}{|c|c|c|}
\hline Non-Balkan route countries & Belgium & $53 \%$ \\
\hline Non-Balkan route countries & Denmark & $13 \%$ \\
\hline Non-Balkan route countries & France & $14 \%$ \\
\hline Non-Balkan route countries & Germany & $12 \%$ \\
\hline Non-Balkan route countries & Ireland & $38 \%$ \\
\hline Non-Balkan route countries & Italy & $18 \%$ \\
\hline Non-Balkan route countries & Norway & $21 \%$ \\
\hline Non-Balkan route countries & Portugal & $17 \%$ \\
\hline Non-Balkan route countries & Spain & $56 \%$ \\
\hline Non-Balkan route countries & Switzerland & $14 \%$ \\
\hline Non-Balkan route countries & United Kingdom & $81 \%$ \\
\hline France & Non-Balkan route countries & N.A \\
\hline fYR of Macedonia & Albania & $42 \%$ \\
\hline fYR of Macedonia & Kosovo & $100 \%$ \\
\hline fYR of Macedonia & Slovenia & $10 \%$ \\
\hline fYR of Macedonia & Switzerland & $5 \%$ \\
\hline Germany & Austria & $11 \%$ \\
\hline Germany & Non-Balkan route countries & N.A \\
\hline Germany & Norway & $79 \%$ \\
\hline Germany & Portugal & $16 \%$ \\
\hline Germany & Switzerland & $17 \%$ \\
\hline Germany & Netherlands & $14 \%$ \\
\hline Greece & Non-Balkan route countries & N.A \\
\hline Greece & fYR of Macedonia & $13 \%$ \\
\hline Greece & Italy & $21 \%$ \\
\hline Hungary & Austria & $34 \%$ \\
\hline Hungary & Slovakia & $40 \%$ \\
\hline Hungary & Slovenia & $12 \%$ \\
\hline Hungary & Sweden & $6 \%$ \\
\hline Iran (Islamic Republic of) & Bulgaria & $10 \%$ \\
\hline Iran (Islamic Republic of) & Non-Balkan route countries & N.A \\
\hline Iran (Islamic Republic of) & Sweden & $16 \%$ \\
\hline Iran (Islamic Republic of) & Turkey & $100 \%$ \\
\hline Italy & Non-Balkan route countries & N.A \\
\hline Italy & Germany & $5 \%$ \\
\hline Italy & Spain & $15 \%$ \\
\hline Italy & Sweden & $22 \%$ \\
\hline Italy & Switzerland & $23 \%$ \\
\hline Kosovo & Albania & $6 \%$ \\
\hline Kosovo & Montenegro & $41 \%$ \\
\hline Kosovo & Slovenia & $15 \%$ \\
\hline Luxembourg & France & $3 \%$ \\
\hline Montenegro & Bosnia and Herzegovina & $53 \%$ \\
\hline Montenegro & Croatia & $9 \%$ \\
\hline Poland & Non-Balkan route countries & N.A \\
\hline Poland & Germany & $7 \%$ \\
\hline Romania & Hungary & $68 \%$ \\
\hline
\end{tabular}




\begin{tabular}{|c|c|c|}
\hline Romania & Poland & $9 \%$ \\
\hline Serbia & Bosnia and Herzegovina & $33 \%$ \\
\hline Serbia & Croatia & $7 \%$ \\
\hline Serbia & Hungary & $7 \%$ \\
\hline Serbia & Montenegro & $18 \%$ \\
\hline Serbia & Slovakia & $50 \%$ \\
\hline Slovenia & Italy & $5 \%$ \\
\hline Slovenia & Switzerland & $10 \%$ \\
\hline Spain & Non-Balkan route countries & N.A \\
\hline Spain & Portugal & $21 \%$ \\
\hline Netherlands & Austria & $19 \%$ \\
\hline Netherlands & France & $10 \%$ \\
\hline Netherlands & Germany & $6 \%$ \\
\hline Netherlands & Ireland & $48 \%$ \\
\hline Netherlands & Luxembourg & $9 \%$ \\
\hline Netherlands & Portugal & $46 \%$ \\
\hline Netherlands & Spain & $9 \%$ \\
\hline Netherlands & United Kingdom & $8 \%$ \\
\hline Turkey & Albania & $48 \%$ \\
\hline Turkey & Belgium & $25 \%$ \\
\hline Turkey & Bulgaria & $90 \%$ \\
\hline Turkey & Czech Republic & $68 \%$ \\
\hline Turkey & Non-Balkan route countries & N.A \\
\hline Turkey & France & $57 \%$ \\
\hline Turkey & fYR of Macedonia & $48 \%$ \\
\hline Turkey & Germany & $50 \%$ \\
\hline Turkey & Greece & $81 \%$ \\
\hline Turkey & Hungary & $25 \%$ \\
\hline Turkey & Italy & $24 \%$ \\
\hline Turkey & Poland & $73 \%$ \\
\hline Turkey & Romania & $12 \%$ \\
\hline Turkey & Serbia & $29 \%$ \\
\hline Turkey & Slovenia & $30 \%$ \\
\hline Turkey & Spain & $14 \%$ \\
\hline Turkey & Switzerland & $8 \%$ \\
\hline Turkey & Netherlands & $78 \%$ \\
\hline Turkey & United Kingdom & $11 \%$ \\
\hline United Kingdom & Denmark & $76 \%$ \\
\hline
\end{tabular}

Source: based on UNODC data.

\subsubsection{The quantity of opiates trafficked through each link}

By combining the country trafficking network with the combined quantity of illicit opiates consumed and seized for each country, it is possible to estimate the quantity trafficked through each link.

The model assumes a volume of illicit opiates is imported into each country $\left(I_{i}\right)$ equal to the sum of its internal consumption $\left(C_{i}\right)$ and seizures $\left(S_{i}\right)$, plus exports to other Balkan route countries $\left(X_{i k}\right)$, plus exports to non-Balkan route countries $\left(X_{i n b i}\right)\left[I_{i}=\left(C_{i}+S_{i}\right)+\sum_{k=1}^{K} X_{i k}+\sum_{n b i=1}^{N B I} X_{i n b i}\right]$. In the previous formula, $K$ and $N B I$ are, respectively, the total numbers of Balkan route countries and non-Balkan route countries to which the country $i$ exports illicit opiates. 
Exports depend on the imports of the next countries on the Balkan route. It is therefore possible to backward calculate the volume traded between each pair of countries once the connection coefficients and the combined quantity of illicit opiates consumed and seized in the final destination markets are known (see Annex.1.2 for the estimate of the connection coefficients and Annex.1.3 for the estimate of the country-specific combined quantity of illicit opiates consumed and seized).

Table A 11. Imports/exports (kilograms of pure heroin equivalent), Balkan route countries/territory, 2009-2012 average

\begin{tabular}{|c|c|c|c|c|}
\hline Exported from & Trafficked to & Low estimate & Best estimate & High estimate \\
\hline Afghanistan & Iran (Islamic Republic of) & $139,614.44$ & $154,782.41$ & $171,635.70$ \\
\hline Albania & Greece & 368.78 & 450.67 & 541.65 \\
\hline Albania & Italy & $1,459.36$ & $1,807.85$ & $2,195.06$ \\
\hline Albania & Montenegro & 114.55 & 142.67 & 173.92 \\
\hline Albania & Slovenia & 36.16 & 44.86 & 54.54 \\
\hline Austria & Czech Republic & 145.43 & 182.00 & 222.63 \\
\hline Austria & Non-Balkan route countries & 47.88 & 59.42 & 72.23 \\
\hline Austria & Germany & 751.40 & 936.07 & $1,141.25$ \\
\hline Austria & Slovakia & 17.96 & 22.54 & 27.62 \\
\hline Austria & Switzerland & 250.59 & 309.55 & 375.06 \\
\hline Belgium & Non-Balkan route countries & 31.30 & 37.66 & 44.74 \\
\hline Belgium & France & $1,182.96$ & $1,474.32$ & $1,798.04$ \\
\hline Belgium & Ireland & 106.60 & 133.03 & 162.40 \\
\hline Belgium & Luxembourg & 296.24 & 368.20 & 448.16 \\
\hline Belgium & Spain & 191.17 & 237.13 & 288.21 \\
\hline Belgium & Sweden & 71.20 & 88.77 & 108.29 \\
\hline Bosnia and Herzegovina & Montenegro & 15.04 & 18.73 & 22.83 \\
\hline Bosnia and Herzegovina & Slovenia & 98.69 & 122.45 & 148.86 \\
\hline Bulgaria & Albania & 94.34 & 116.66 & 141.46 \\
\hline Bulgaria & Austria & 776.42 & 964.90 & $1,174.33$ \\
\hline Bulgaria & Belgium & 564.93 & 697.28 & 844.34 \\
\hline Bulgaria & Croatia & 454.61 & 565.57 & 688.86 \\
\hline Bulgaria & Non-Balkan route countries & 57.80 & 69.28 & 82.03 \\
\hline Bulgaria & Germany & $1,237.17$ & $1,541.23$ & $1,879.07$ \\
\hline Bulgaria & Greece & 206.75 & 252.66 & 303.67 \\
\hline Bulgaria & Italy & $1,201.91$ & $1,488.92$ & $1,807.83$ \\
\hline Bulgaria & fYR of Macedonia & 787.11 & 971.40 & $1,176.17$ \\
\hline Bulgaria & Netherlands & 364.84 & 447.43 & 539.18 \\
\hline Bulgaria & Poland & 301.45 & 376.98 & 460.91 \\
\hline Bulgaria & Romania & $1,270.41$ & $1,579.29$ & $1,922.49$ \\
\hline Bulgaria & Serbia & 626.57 & 783.36 & 957.58 \\
\hline Bulgaria & Sweden & 210.39 & 262.32 & 320.01 \\
\hline Croatia & Bosnia and Herzegovina & 59.09 & 73.73 & 90.00 \\
\hline Croatia & Slovenia & 105.02 & 130.31 & 158.42 \\
\hline Czech Republic & Denmark & 74.17 & 92.68 & 113.25 \\
\hline Non-Balkan route countries & Belgium & $1,317.26$ & $1,625.88$ & $1,968.80$ \\
\hline Non-Balkan route countries & Denmark & 87.03 & 108.76 & 132.90 \\
\hline Non-Balkan route countries & France & $1,125.26$ & $1,402.41$ & $1,710.35$ \\
\hline Non-Balkan route countries & Germany & $1,188.24$ & $1,480.27$ & $1,804.75$ \\
\hline
\end{tabular}




\begin{tabular}{|c|c|c|c|c|}
\hline Non-Balkan route countries & Ireland & 289.78 & 361.63 & 441.46 \\
\hline Non-Balkan route countries & Italy & $1,461.13$ & $1,810.04$ & $2,197.72$ \\
\hline Non-Balkan route countries & Norway & 79.34 & 97.57 & 117.82 \\
\hline Non-Balkan route countries & Portugal & 126.03 & 156.87 & 191.13 \\
\hline Non-Balkan route countries & Spain & $1,660.30$ & $2,059.51$ & $2,503.08$ \\
\hline Non-Balkan route countries & Switzerland & 155.99 & 192.69 & 233.47 \\
\hline Non-Balkan route countries & United Kingdom & $10,600.09$ & $13,158.96$ & $16,002.14$ \\
\hline France & Non-Balkan route countries & 376.06 & 468.68 & 571.59 \\
\hline Germany & Austria & 241.15 & 299.69 & 364.73 \\
\hline Germany & Non-Balkan route countries & 393.04 & 490.61 & 599.03 \\
\hline Germany & Netherlands & 662.35 & 812.27 & 978.84 \\
\hline Germany & Norway & 292.03 & 359.11 & 433.64 \\
\hline Germany & Portugal & 115.79 & 144.13 & 175.61 \\
\hline Germany & Switzerland & 192.96 & 238.37 & 288.81 \\
\hline Greece & Non-Balkan route countries & 49.54 & 59.01 & 69.54 \\
\hline Greece & Italy & $1,735.18$ & $2,149.54$ & $2,609.93$ \\
\hline Greece & fYR of Macedonia & 248.86 & 307.13 & 371.88 \\
\hline Hungary & Austria & 747.81 & 929.35 & $1,131.06$ \\
\hline Hungary & Slovakia & 71.86 & 90.14 & 110.46 \\
\hline Hungary & Slovenia & 84.36 & 104.68 & 127.25 \\
\hline Hungary & Sweden & 33.22 & 41.42 & 50.53 \\
\hline Iran (Islamic Republic of) & Bulgaria & 952.26 & $1,176.46$ & $1,425.56$ \\
\hline Iran (Islamic Republic of) & Non-Balkan route countries & $4,583.27$ & $4,913.74$ & $5,280.93$ \\
\hline Iran (Islamic Republic of) & Sweden & 83.19 & 103.72 & 126.53 \\
\hline Iran (Islamic Republic of) & Turkey & $42,330.29$ & $50,313.69$ & $59,184.13$ \\
\hline Italy & Non-Balkan route countries & 328.98 & 407.34 & 494.41 \\
\hline Italy & Germany & 481.55 & 599.90 & 731.40 \\
\hline Italy & Spain & 451.32 & 559.83 & 680.41 \\
\hline Italy & Sweden & 114.22 & 142.41 & 173.73 \\
\hline Italy & Switzerland & 250.59 & 309.55 & 375.06 \\
\hline Kosovo & Albania & 143.90 & 177.95 & 215.78 \\
\hline Kosovo & Montenegro & 131.81 & 164.17 & 200.12 \\
\hline Kosovo & Slovenia & 109.43 & 135.78 & 165.06 \\
\hline Luxembourg & France & 251.84 & 313.86 & 382.78 \\
\hline fYR of Macedonia & Albania & 986.74 & $1,220.22$ & $1,479.64$ \\
\hline fYR of Macedonia & Kosovo & 574.22 & 709.09 & 858.95 \\
\hline fYR of Macedonia & Slovenia & 72.31 & 89.72 & 109.07 \\
\hline fYR of Macedonia & Switzerland & 57.77 & 71.37 & 86.47 \\
\hline Montenegro & Bosnia and Herzegovina & 213.18 & 266.01 & 324.72 \\
\hline Montenegro & Croatia & 49.76 & 61.91 & 75.40 \\
\hline Netherlands & Austria & 405.52 & 503.97 & 613.36 \\
\hline Netherlands & France & 809.39 & $1,008.74$ & $1,230.24$ \\
\hline Netherlands & Germany & 540.17 & 672.93 & 820.44 \\
\hline Netherlands & Ireland & 371.51 & 463.63 & 565.98 \\
\hline Netherlands & Luxembourg & 30.18 & 37.51 & 45.66 \\
\hline Netherlands & Portugal & 340.61 & 423.95 & 516.55 \\
\hline Netherlands & Spain & 273.34 & 339.06 & 412.08 \\
\hline
\end{tabular}




\begin{tabular}{|c|c|c|c|c|}
\hline Netherlands & United Kingdom & $1,008.63$ & $1,252.12$ & $1,522.66$ \\
\hline Poland & Non-Balkan route countries & 48.48 & 60.78 & 74.44 \\
\hline Poland & Germany & 640.03 & 797.33 & 972.10 \\
\hline Romania & Hungary & 735.35 & 912.23 & $1,108.78$ \\
\hline Romania & Poland & 150.75 & 188.52 & 230.49 \\
\hline Serbia & Bosnia and Herzegovina & 133.77 & 166.92 & 203.76 \\
\hline Serbia & Croatia & 40.80 & 50.76 & 61.83 \\
\hline Serbia & Hungary & 73.78 & 91.52 & 111.24 \\
\hline Serbia & Montenegro & 58.71 & 73.12 & 89.13 \\
\hline Serbia & Slovakia & 88.43 & 110.93 & 135.94 \\
\hline Slovenia & Italy & 381.92 & 473.12 & 574.46 \\
\hline Slovenia & Switzerland & 115.55 & 142.73 & 172.94 \\
\hline Spain & Non-Balkan route countries & 134.35 & 166.62 & 202.48 \\
\hline Spain & Portugal & 157.10 & 195.54 & 238.25 \\
\hline Turkey & Albania & $1,109.35$ & $1,371.84$ & $1,663.50$ \\
\hline Turkey & Belgium & 623.20 & 769.21 & 931.44 \\
\hline Turkey & Bulgaria & $8,358.51$ & $10,326.40$ & $12,512.94$ \\
\hline Turkey & Czech Republic & 316.13 & 395.62 & 483.94 \\
\hline Turkey & Non-Balkan route countries & 446.28 & 453.02 & 460.51 \\
\hline Turkey & France & $4,527.72$ & $5,642.87$ & $6,881.92$ \\
\hline Turkey & Germany & $4,919.64$ & $6,128.73$ & $7,472.17$ \\
\hline Turkey & Greece & $2,448.91$ & $2,992.66$ & $3,596.82$ \\
\hline Turkey & Hungary & 268.01 & 332.48 & 404.12 \\
\hline Turkey & Italy & $1,966.80$ & $2,436.47$ & $2,958.32$ \\
\hline Turkey & fYR of Macedonia & 950.21 & $1,172.70$ & $1,419.90$ \\
\hline Turkey & Netherlands & $3,622.29$ & $4,442.17$ & $5,353.16$ \\
\hline Turkey & Poland & $1,206.01$ & $1,508.19$ & $1,843.95$ \\
\hline Turkey & Romania & 175.13 & 217.71 & 265.02 \\
\hline Turkey & Serbia & 262.04 & 327.62 & 400.48 \\
\hline Turkey & Slovenia & 218.85 & 271.56 & 330.12 \\
\hline Turkey & Spain & 402.31 & 499.04 & 606.52 \\
\hline Turkey & Switzerland & 83.64 & 103.33 & 125.19 \\
\hline Turkey & United Kingdom & $1,499.62$ & $1,861.63$ & $2,263.86$ \\
\hline United Kingdom & Denmark & 519.17 & 648.77 & 792.78 \\
\hline
\end{tabular}

Note: different assumptions on per-user annual consumption of illicit opiates determines the three estimates (see Box A 10).

Source: based on UNODC data.

\subsubsection{Cross-check validity of demand-side estimates with supply-side estimates}

Given the data limitations, the present study performs a simple discrepancy analysis by crosschecking the estimates of the demand for illicit opiates with those of supply in order to verify the consistency of its findings. ${ }^{119}$

To estimate the quantity of opiates produced in Afghanistan, which are exported to the Balkan route $\left(E X_{a f}\right)$, it is necessary to purge total Afghan opium production $\left(O P_{a f}\right)$ of internal seizures $\left(S_{a f}\right)$ and internal consumption $\left(I C_{a f}\right)$. Although some studies acknowledge that part of opium produced may be stockpiled or even lost, there are no elements with which to compute a sound estimate of them. ${ }^{120}$ The next step is to determine the share of exports directed solely to the Balkan route (s_ebr). It follows that the estimate of total supply is: $E X_{a f}=\left(O P_{a f}-S_{a f}-I C_{a f}\right) \cdot s_{-} e b r$.

\footnotetext{
${ }^{119}$ OECD, Measuring the Non-Observed Economy. A Handbook.
}

${ }^{120}$ UNODC, The Global Afghan Opium Trade. 
UNODC provides annual estimates of total opium production $\left(O P_{a f}\right)$, seizures $\left(S_{a f}\right)$ and consumption $\left(I C_{a f}\right)$ for Afghanistan from 2009 to 2012 (see Table A 12). ${ }^{121}$ Available data indicates that 81 per cent of the raw opium and 49 per cent of the heroin available for export in Afghanistan are destined for the Balkan route (s_ebr) (see Table A 13). ${ }^{122}$ Considering all these factors, the average quantity of opium available for export is 3,766 tons (range: 2,943-4,461 tons).

Table A 12. Potential opium production, seizures, consumption and remainder for export in Afghanistan (tons), 2009-2012 average

\begin{tabular}{|c|c|c|c|c|c|}
\hline & $\begin{array}{l}\text { Afghan Opium } \\
\text { Survey } 2012\end{array}$ & $\begin{array}{l}\text { Afghan Opium } \\
\text { Survey } 2011\end{array}$ & $\begin{array}{l}\text { Afghan Opium } \\
\text { Survey } 2010\end{array}$ & $\begin{array}{l}\text { Afghan Opium } \\
\text { Survey } 2009\end{array}$ & $\begin{array}{c}\text { Average } \\
2009-2012\end{array}$ \\
\hline \multicolumn{6}{|l|}{$\begin{array}{l}\text { Potential opium } \\
\text { production }\end{array}$} \\
\hline Low estimate & 2,800 & 4,800 & 3,000 & 3,400 & \multirow{5}{*}{-} \\
\hline Best estimate & 3,700 & 5,800 & 3,600 & 4,000 & \\
\hline High estimate & 4,200 & 6,800 & 4,200 & 4,600 & \\
\hline Seizures & 507 & 227 & 93 & 238 & \\
\hline Consumption & 258 & 258 & 298 & 156 & \\
\hline \multicolumn{6}{|l|}{ Remainder for export } \\
\hline Low estimate & 1,996 & 4,276 & 2,564 & 2,935 & 2,943 \\
\hline Best estimate & 2,935 & 5,315 & 3,209 & 3,606 & 3,766 \\
\hline High estimate & 3,455 & 6,335 & 3,834 & 4,219 & 4,461 \\
\hline Converted into heroin & $42.0 \%$ & $50.0 \%$ & $52.0 \%$ & $58.0 \%$ & $50.5 \%$ \\
\hline
\end{tabular}

Source: elaboration on UNODC.

Table A 13. Shares of opium and heroin trafficked to the Islamic Republic of Iran according to the estimate method (percentages), 2009 and 2010

\section{Afghan Opium Survey 2010}

Afghan Opium Survey 2009

Average

\begin{tabular}{|lrr|}
\hline Method & Opium & Heroin \\
\hline Seizures & $95 \%$ & $72 \%$ \\
\hline Opium flows & $71 \%$ & $62 \%$ \\
\hline Trafficking route & $81 \%$ & $31 \%$ \\
\hline Seizures & $95 \%$ & $53 \%$ \\
\hline Opium flows & $64 \%$ & $57 \%$ \\
\hline Trafficking route & $77 \%$ & $28 \%$ \\
\hline Lab location & & $39 \%$ \\
& $\mathbf{8 1 \%}$ & $\mathbf{4 9 \%}$
\end{tabular}

Source: elaboration on UNODC.

Afghanistan may export 204 tons of illicit opiates in pure heroin equivalent (range: 159-241 tons) (see Table A 14). This value relies on the share of illicit opiates destined for export and a conversion factor of 18.5 units of opium to produce a single unit of pure heroin equivalent. ${ }^{123}$ Combining these values with the information on the share of opiates exported to the Islamic Republic of Iran (81 per cent of opium and 49 per cent of heroin production); shows that 130.7 tons (range: 102.2-154.7 tons) of illicit opiates in pure heroin equivalent are exported to the Islamic Republic of Iran.

\footnotetext{
${ }^{121}$ UNODC and Islamic Republic of Afghanistan - Ministry of Counter Narcotics, Afghanistan Opium Survey (Vienna, 2012, 2011, 2010, 2009). ${ }^{122}$ UNODC and Islamic Republic of Afghanistan - Ministry of Counter Narcotics, Afghanistan Opium Survey (Vienna, 2010, 2009).

${ }^{123}$ UNODC and Islamic Republic of Afghanistan - Ministry of Counter-Narcotics, Afghan Opium Survey (Vienna, 2014).
} 
Table A 14. Quantity of opiates available on the Balkan route, estimated from supply (tons), 2009-2012 average

\begin{tabular}{lrrr} 
& \multicolumn{3}{c}{ Illicit opiates (tons) } \\
& Low estimate & Best estimate & High estimate \\
\hline Illicit opiates available for export in opium equivalent & 2,942 & 3,766 & 4,460 \\
\hline Illicit opiates available for export in pure heroin equivalent & 159.0 & 203.6 & 241.1 \\
\hline Afghan opium available along the Balkan route in pure & 102.2 & 130.7 & 154.7
\end{tabular}

heroin equivalent

Source: elaboration on UNODC.

The previous part presented the estimate of the combined quantity of illicit opiates consumed and seized in the Balkan route countries. It emerges from the analysis that the total demand for illicit opiates in pure heroin equivalent is 170.0 tons (range: 151.2-191.0 tons) for the period 2009-2012. The net import (imports minus exports) from nonBalkan route countries is 15.3 tons (range: 11.6-19.3 tons). Consequently, the estimate of the flow of illicit opiates to the Balkan route applying the demand-based approach is 154.8 tons (range: 139.6-171.7 tons).

The discrepancy analysis indicates that, on adopting a supply-side approach, the best estimate of the flow of illicit opiates to the Balkan route would be 16 per cent lower. Moreover, the best estimate of the demand-side approach (154.8 tons) is closer to the higher estimate of the supply-side approach (154.7 tons) than to its best estimate (130.7 tons) (see Figure A 1). Given the difficulties in estimating the size of an illegal market like the one for illicit opiates, some differences were expected. ${ }^{124}$ The fact that the demand-side approach adopted determines a higher volume of illicit opiates than the supply-side approach suggests that the final estimates of the gross profit may be upwardbiased.

Figure A 1. Crosscheck validity of the demand-side estimates with supply-side estimates (tons)
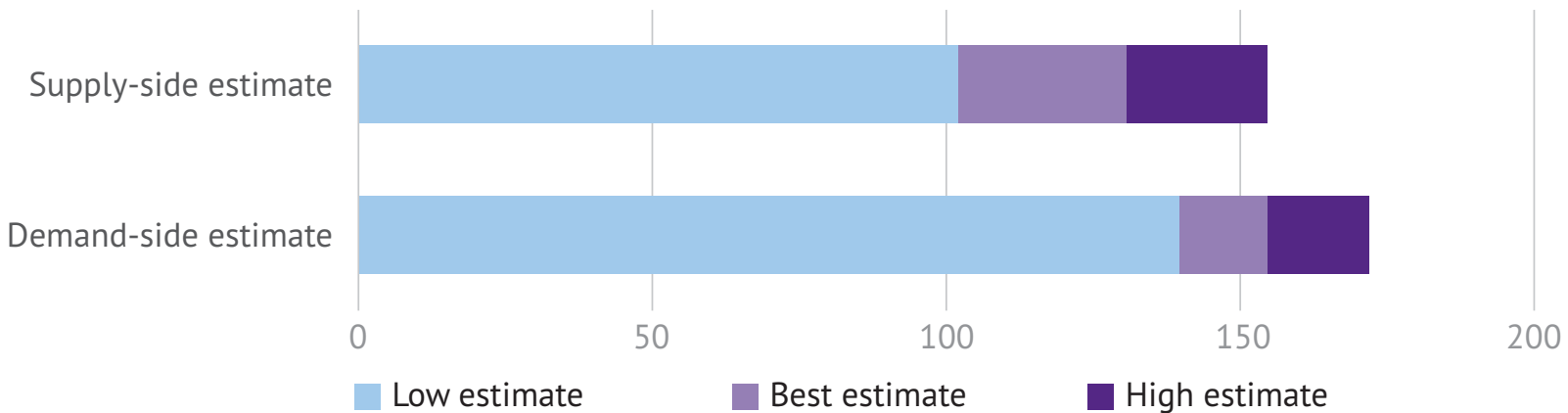

Source: based on UNODC data.

\section{Annex.1.3. The gross profit of illicit opiate trafficking - Step 3}

UNODC and the Financial Action Task Force have developed a framework to estimate the amount of money originating from opiate trafficking. The framework approaches opiate trafficking as a business aimed at achieving economic profits. Production, manufacturing, distribution and retail are the constituent parts of this business. ${ }^{125}$

The map of the country network and the estimates of the volumes of opiate shipments allow application of this framework to calculate the gross profit generated on the Balkan route. The operationalization of the framework generates the formula [ $G P=R+D$ ], where $R$ is the gross profit at retail level (Annex 1.3.1) and $D$ is the gross profit at distribution level inclusive of the costs of producing raw opium and of the costs of manufacturing heroin (Annex 1.3.2).

\footnotetext{
${ }^{124}$ Peter Reuter and Victoria Greenfield, "Measuring Global Drug Markets. How Good Are the Numbers and Why Should We Care about Them?," World Economics 2, no. 4 (2001): 159-73.

${ }^{125}$ Islamic Republic of Afghanistan - Ministry of Counter Narcotic, Afghanistan Drug Report 2013, December 2014, http://www.unodc.org/ documents/afghanistan//Afghanistan_Drug_Report_2013.pdf.
} 
The resulting estimate includes transactions mutually agreed by purchasers and the sellers and follows basic principles of economic accounting. In this way, the resulting gross profit is GDP comparable (see Annex 2). ${ }^{126}$

\subsubsection{Gross profit at the Retail level}

Retail is the last stage of the supply chain of illicit opiates. Here gross profit at the retail level is obtained by subtracting the cost of purchasing the illicit opiates at the wholesale level from the revenues at retail. In particular, total consumption $\left(C_{i}\right)$ multiplied by the price at retail $\left(R P_{i}\right)$ gives the revenue at the retail level. The wholesale price at sale $\left(p r_{i w h}{ }^{s}\right)$, multiplied by quantities purchased at the wholesale level $\left(R Q_{i}\right)$, gives the costs sustained by retailers. With respect to country $i$, the gross profit at the retail level is: $R_{i}=C_{i} \cdot R P_{i}-R Q_{i} \cdot p r_{i w h}{ }^{s}$ (see Table A 15). $R Q_{i}$ is obtained by summing the national consumption $\left(C_{j}\right)$ and seizures at the retail level $\left(S_{i}^{\perp-R}\right)$.

Table A 15. Gross profit at the retail level made from illicit opiates trafficked on the Balkan route (millions of United States dollars), by country/territory, 2009-2012 average

\begin{tabular}{|c|c|c|c|}
\hline & Low estimate & Best estimate & High estimate \\
\hline Albania & 105 & 132 & 162 \\
\hline Austria & 483 & 607 & 745 \\
\hline Belgium & 63 & 79 & 97 \\
\hline Bosnia and Herzegovina & 12 & 16 & 19 \\
\hline Bulgaria & 128 & 161 & 197 \\
\hline Croatia & 75 & 94 & 115 \\
\hline Czech Republic & 57 & 72 & 88 \\
\hline Denmark & 237 & 299 & 366 \\
\hline France & 2,279 & 2,865 & 3,517 \\
\hline Germany & 1,460 & 1,836 & 2,253 \\
\hline Greece & 107 & 134 & 165 \\
\hline Hungary & 17 & 21 & 26 \\
\hline Iran (Islamic Republic of) & 3,471 & 4,329 & 5,283 \\
\hline Ireland & 255 & 321 & 394 \\
\hline Italy & 448 & 564 & 692 \\
\hline Kosovo & 10 & 12 & 15 \\
\hline Luxembourg & 25 & 31 & 38 \\
\hline fYR of Macedonia & 15 & 18 & 23 \\
\hline Montenegro & 4 & 5 & 6 \\
\hline Netherlands & 29 & 36 & 44 \\
\hline Norway & 196 & 246 & 302 \\
\hline Poland & 118 & 148 & 182 \\
\hline Portugal & 79 & 99 & 122 \\
\hline Romania & 47 & 59 & 73 \\
\hline Serbia & 15 & 18 & 23 \\
\hline Slovakia & 79 & 99 & 121 \\
\hline Slovenia & 35 & 44 & 54 \\
\hline Spain & 314 & 394 & 484 \\
\hline Sweden & 328 & 413 & 507 \\
\hline Switzerland & 274 & 344 & 422 \\
\hline Turkey & 23 & 30 & 36 \\
\hline United Kingdom & 1,286 & 1,618 & 1,985 \\
\hline Balkan route & 12,072 & 15,144 & 18,556 \\
\hline Afghanistan & 92 & 92 & 92 \\
\hline
\end{tabular}

Note: different assumptions on per-user annual consumption of illicit opiates determines the three estimates (see Box A 10).

Source: based on UNODC data.

${ }^{126}$ OECD, Measuring the Non-Observed Economy. A Handbook. 


\subsubsection{Gross profit at the Distribution level}

The study divides the distribution level into two sub-levels; starting from final consumption, the first sub-level is wholesale $(W i)$ and the second is international trafficking $(T I)$. Wholesale refers to the handling of large quantities of drugs domestically. ${ }^{127}$ International trafficking refers to the traffic of large quantities of illicit opiates across international boundaries and their distribution to wholesalers in final markets. ${ }^{128}$

Whilst scholars agree on the existence of multiple stages in the supply chain of illicit drugs between production and the final consumer, their number and their true nature are debated. There is no unique definition of the different levels of the heroin market and how revenue at these levels should be divided. ${ }^{129}$ Therefore, the modelling adopted by the current study has to be intended as an operationalization necessary to quantify a complex and fluid phenomenon rather than an exact representation of the supply chain of opiate trafficking.

\subsubsection{Gross profit at the Wholesale level}

The gross profit at the wholesale level in a country is given by the difference between the value of the sale to retailers active in the country and the cost of purchasing products from international traffickers.

Wholesalers sell to retailers a volume equivalent to internal consumption $\left(C_{i}\right)$ plus seizures at the retail level $\left(S_{i}^{i_{i}-R}\right)$. Revenues at the wholesale level are given by this volume times the wholesale price at which wholesalers sell illicit opiates to final retailers $\left(p r_{i w h}{ }^{s}\right.$ ) (see Annex 4 for the calculation of prices). The wholesale price at purchase $\left(p r_{i w h}{ }^{p}\right)$ multiplied by the purchased quantities at the wholesale level gives the total costs sustained by wholesalers. The volume purchased by wholesalers is equal to internal consumption $\left(C_{i}\right)$ plus seizures at the retail level $\left(S_{i}^{I-R}\right)$ plus seizures at the wholesale level $\left(S_{i}{ }^{-W}\right)$. In order to make the quantities comparable, all the prices are purityadjusted (see Annex 3 for the calculus of purities). With respect to country $i$, the revenues at the wholesale level are: $W_{i}=\left(C_{i}+S_{i}^{\lfloor-R}\right) \cdot p r_{i w h}{ }^{S}-\left(C_{i}+S_{i}^{\lfloor-R}+S_{i}^{!-W}\right) \cdot p r_{i w h}{ }^{p}($ see Table A 16).

\footnotetext{
${ }^{127}$ Peter Reuter and Franz Trautmann, “Global Illicit Drug Markets 1998 - 2007” (Lisbon: Timbros Institute, RAND Corporation, 2009).

${ }^{128}$ FATF/OECD, "Financial Flows Linked to the Production and Trafficking of Afghan Opiates" (Paris: Financial Action Task Force/ Organisation for Economic Co-operation and Development, 2014).

${ }^{129}$ UNDCP, "Economic and Social Consequences of Drug Abuse and Illicit Trafficking" (Vienna: United Nations International Drug Control Programme, 1998); UNODC, World Drug Report 2005 (Vienna: United Nation Office on Drugs and Crime, 2005), http://www.unodc.org/ pdf/WDR_2005/volume_1_web.pdf; Timothy J. Moore et al., "Monograph No. 09: Heroin Markets in Australia: Current Understandings and Future Possibilities," DPMP Monograph Series (Fitzroy: Turning Point Alcohol and Drug Centre, 2005); Martin Bouchard and Chris Wilkins, Illegal Markets and the Economics of Organized Crime (New York: Routledge, 2010); EMCDDA, "Pilot Study on Wholesale Drug Prices in Europe"; FATF/OECD, "Financial Flows Linked to the Production and Trafficking of Afghan Opiates."
} 
Table A 16. Gross profit at the wholesale level made from illicit opiates trafficked on the Balkan route (millions of United States dollars), by country/territory, 2009-2012 average

\begin{tabular}{|c|c|c|c|}
\hline & Low estimate & Best estimate & High estimate \\
\hline Albania & 51 & 64 & 79 \\
\hline Austria & 138 & 174 & 213 \\
\hline Belgium & 7 & 9 & 11 \\
\hline Bosnia and Herzegovina & 9 & 12 & 14 \\
\hline Bulgaria & 77 & 97 & 119 \\
\hline Croatia & 48 & 61 & 75 \\
\hline Czech Republic & 32 & 40 & 49 \\
\hline Denmark & 69 & 87 & 106 \\
\hline France & 846 & 1,064 & 1,307 \\
\hline Germany & 252 & 317 & 389 \\
\hline Greece & 14 & 17 & 22 \\
\hline Hungary & 2 & 3 & 4 \\
\hline Iran (Islamic Republic of) & 602 & 759 & 933 \\
\hline Ireland & 135 & 170 & 209 \\
\hline Italy & 330 & 415 & 510 \\
\hline Kosovo & 4 & 5 & 6 \\
\hline Luxembourg & 4 & 5 & 6 \\
\hline fYR of Macedonia & 3 & 4 & 5 \\
\hline Montenegro & 2 & 2 & 3 \\
\hline Netherlands & 11 & 13 & 16 \\
\hline Norway & 55 & 70 & 86 \\
\hline Poland & 34 & 42 & 52 \\
\hline Portugal & 20 & 25 & 31 \\
\hline Romania & 21 & 27 & 33 \\
\hline Serbia & 3 & 4 & 5 \\
\hline Slovakia & 14 & 17 & 21 \\
\hline Slovenia & 14 & 18 & 22 \\
\hline Spain & 113 & 142 & 175 \\
\hline Sweden & 50 & 64 & 78 \\
\hline Switzerland & 34 & 43 & 52 \\
\hline Turkey & 9 & 11 & 14 \\
\hline United Kingdom & 642 & 809 & 993 \\
\hline Balkan route & 3,645 & 4,589 & 5,638 \\
\hline Afghanistan & 61 & 61 & 61 \\
\hline
\end{tabular}

Note: different assumptions on per-user annual consumption of illicit opiates determine the three estimates (see Box A 10).

Source: based on UNODC data.

\subsubsection{Gross profit at the international trade level $-T_{i}$}

The combination of five elements gives the gross profit at the international trade level $\left(T_{i}\right)$. The first two are the revenues from the sale of opiates to national wholesalers $\left(W r_{i}\right)$ and from the international trade of illicit opiates $\left(T r_{i}\right)$. The other three are the costs related to the purchases of illicit opiates on the international market $\left(T C_{i}\right)$, to the manufacturing of heroin $\left(C M_{i}\right)$, and to the production of raw opium $\left(C P_{i}\right)\left[T_{i}=W r_{i}+T r_{i}-T C_{i}-C M_{i}-C P_{i}\right]$ (see Table A 17). 
The estimate does not directly asses the monetary value of ancillary services and costs as cross-border transportation, guard services and bribes. The margins of traffickers are assumed to include these elements of the opiate economy, which consequently enter into the estimate of the gross profit.

Table A 17. Gross profit at the international trade level made from illicit opiates trafficked on the Balkan route (millions of United States dollars), by country/territory, 2009-2012 average

\section{Low estimate}

Albania

Austria

Belgium

Bosnia and Herzegovina

Bulgaria

Croatia

Czech Republic

Denmark

France

Germany

Greece

Hungary

Iran (Islamic Republic of)

Ireland

Italy

Kosovo

Luxembourg

fYR of Macedonia

Montenegro

Netherlands

Norway

Poland

Portugal

Romania

Serbia

Slovakia

Slovenia

Spain

Sweden

Switzerland

Turkey

United Kingdom

Balkan route

Afghanistan

\begin{tabular}{|c|}
\hline 100 \\
\hline 180 \\
\hline 28 \\
\hline 28 \\
\hline \\
\hline \\
\hline
\end{tabular}

6,724
Best estimate

$100 \quad 124$

180

$28 \quad 35 \quad 43$

$10 \quad 13 \quad 16$

$\begin{array}{lll}288 & 358 & 436\end{array}$

$\begin{array}{lll}54 & 68 & 83\end{array}$

$38 \quad 48 \quad 59$

$\begin{array}{lrr}80 & 101 & 124\end{array}$

$916 \quad 1,150 \quad 1,410$

$377 \quad 473 \quad 579$

$\begin{array}{lll}54 & 67 & 81\end{array}$

$\begin{array}{lrr}22 & 27 & 33\end{array}$

$\begin{array}{lll}2,020 & 2,433 & 2,892\end{array}$

$144 \quad 180 \quad 221$

$\begin{array}{lll}430 & 539 & 659\end{array}$

$\begin{array}{lll}6 & 8 & 9\end{array}$

$\begin{array}{lll}5 & 6 & 7\end{array}$

$\begin{array}{lll}13 & 16 & 19\end{array}$

$3 \quad 4 \quad 5$

$108 \quad 134 \quad 162$

$\begin{array}{lll}59 & 74 & 91\end{array}$

$\begin{array}{lll}69 & 87 & 106\end{array}$

$\begin{array}{lll}27 & 34 & 41\end{array}$

$39 \quad 49 \quad 60$

$\begin{array}{lll}9 & 11 & 14\end{array}$

$\begin{array}{lll}14 & 17 & 21\end{array}$

$25 \quad 31 \quad 38$

$144 \quad 181 \quad 221$

$\begin{array}{lll}56 & 71 & 87\end{array}$

$\begin{array}{lll}40 & 51 & 62\end{array}$

$\begin{array}{llr}588 & 724 & 876\end{array}$

$\begin{array}{lrr}776 & 973 & 1,192\end{array}$

8,311

$197 \quad 204$

10,073

213

Note: different assumptions on per-user annual consumption of illicit opiates determine the three estimates (see Box A 10).

Source: based on UNODC data. 


\subsubsection{Revenues from sale to wholesalers - $W r_{i}$}

International traffickers sell to wholesalers a volume equivalent to internal consumption $\left(C_{i}\right)$ plus seizures at the retail $\left(S_{i}^{!-R}\right)$ and wholesale levels $\left(S_{i}^{\perp-W}\right)$. Revenues from distributing illicit opiates within the country are given by this volume times the unitary price at which traffickers sell illicit opiates to wholesalers ( $p r_{i w h}{ }^{p}$ ) (see Annex 4). In order to make the quantities comparable, all prices are purity-adjusted (see Annex 3 ). With respect to country $i$, the revenues from sale to wholesalers are: $W r_{i}=\left(C_{i}+S_{i} i^{R}+S_{i}{ }^{\lfloor} W\right) \cdot\left(W P_{i}^{R}\right)$

\subsubsection{Revenues from the international trade of illicit opiates - $\operatorname{Tr}_{i}$}

International traffickers generate revenues from the international trade of opiates by importing illicit opiates into their countries and by exporting illicit opiates to other countries. Therefore, with respect to country $i$, the revenues deriving from the international trade are: $\operatorname{Tr}_{i}=\left(\sum_{j=1}^{J} X_{i j} \cdot p r_{i j e x c}{ }^{E}\right) a_{i j}+\left(\sum_{k=1}^{K} I_{i k} \cdot p r_{i k \text { exc }}{ }^{\prime}\right) a_{i k}$

Where:

$\operatorname{Tr}_{i} \quad$ is the revenue derived from the international opiate trade in country $i$

$J \quad$ is the total number of $j$ countries to which $i$ exports opiates

$K \quad$ is the total number of $k$ countries from which $\mathrm{i}$ imports opiates

$X_{j i} \quad$ is the amount of opiates exported to country j

$I_{i k} \quad$ is the amount of opiates imported from country $k$

$\operatorname{pr}_{i j \operatorname{exc}}{ }^{E}$ is the export price at which $\mathrm{i}$ exports to $\mathrm{j}$

$\operatorname{pr}_{i k e x c}{ }^{l}$ is the import price at which $\mathrm{i}$ imports from $\mathrm{k}$

$a_{i j} \quad$ measures the relative involvement of $\mathrm{i}$ citizens in export to $\mathrm{j}$

$a_{i k} \quad$ measures the relative involvement of $\mathrm{i}$ citizens in import from $\mathrm{k}$

By introducing the coefficient $a$, the study attempts to take the nationality of the traffickers into account, rather than allocate the gross profit to the exporting or to the importing countries without considering the actors active between the two countries. $a$ is estimated starting from data on the nationalities of people convicted of drug-related crimes provided by the Delta ARQ database. ${ }^{130}$ The relative importance of actors in one of the two countries involved in the transaction is based on the cumulated shares of people of the two nationalities convicted in the two countries. Hence, the study does not allocate any share of the gross profit at the international trade level to third countries even if the actors from third countries take part in the specific traffic. Specifically, $a_{i j}$, which indicates the relative weight of $i$ actors in the trade between $i$ and $j$, is estimated according to the following formula:

$$
a_{i j}=\left(A_{i}^{i} / A^{i}+A_{i}^{j} / A^{j}\right) /\left(A_{i}^{i} / A^{i}+A_{i}^{j} / A^{j}+A_{j}^{i} / A^{i}+A_{j}^{j} / A^{j}\right)
$$

Conversely, the relative weight of the actors of $\mathrm{j}$ nationality is: $a_{j i}=1-a_{i j}$

Where:

$A_{i}^{i} \quad$ is the number of actors of $i$ nationality convicted for drug-related crimes in $\mathrm{i}$

$A_{i}^{j} \quad$ is the number of actors of $\mathrm{i}$ nationality convicted for drug-related crimes in $\mathrm{j}$

$A_{j}^{j} \quad$ is the number of actors of $\mathrm{j}$ nationality convicted for drug-related crimes in $\mathrm{j}$

$A_{j}^{i} \quad$ is the number of actors of $\mathrm{j}$ nationality convicted for drug-related crimes in $\mathrm{i}$

$A^{i} \quad$ is the total number of people convicted of drug-related crimes in $\mathrm{i}$

$A^{j} \quad$ is the total number of people convicted of drug-related crimes in $\mathrm{j}$

Data used for this estimate cover the 2009-2012 period. The numbers of convictions in each year are summed. Actors in the two countries are considered to have the same relative weight whenever data for one or both countries are not available; in this case $a_{i j}=a_{j i}$. This is a strong assumption given that the actual involvement of citizens of the countries in the opiate trafficking may be strongly unbalanced. No other data allow account to be taken of these possible differences. Likely differences in the levels of law enforcement in the countries may bias the estimate of the coefficient inflating the weight of the countries in which the fight against drug trafficking is more robust. The study deals with this potential bias by taking the numbers of convictions in the form of ratios.

${ }^{130}$ UNODC, Delta Annual Reports Questionnaire Database (2014). 


\subsubsection{Costs of purchase - $T c_{i}$}

Costs for international traffickers derive from their purchase of illicit opiates along the Balkan route. The cost of the illicit opiates that they import is the average exchange price of the countries where they purchase those illicit opiates multiplied by the volume that they import (see Annex.4.1 for the estimate of the exchange prices). The cost of the illicit opiates that they export, on the other hand, is their own average exchange price multiplied by the volume that they export.

\subsubsection{Costs of manufacturing - $C M_{i}$}

While the vast majority of opium is converted to heroin in Afghanistan, regional data show that some heroin may also be manufactured outside Afghanistan (see Table A 18).

The unitary costs for processing raw opium into refined products $(U Z H)$ and volume of raw opium to be converted into refined products $\left(O_{R i}\right)$ determine the total cost of manufacturing $\left(C M_{i}\right)\left[C M_{i}=O_{R i} \cdot U Z H\right]$. The estimate for the cost of manufacturing is based on UNODC data. ${ }^{131}$ These costs enter the estimate of the gross profit generated by international traffickers.

Table A 18. Cost of manufacturing heroin (millions of United States dollars), 2009-2012 average

\section{Low estimate}

Afghanistan Iran (Islamic Republic of)

100

Best estimate

124
High estimate

152

Note: different assumptions on per-user annual consumption of illicit opiates determines different estimates of the demand for heroin of the Balkan route countries and consequently of the costs of manufacturing heroin.

Source: based on UNODC data.

\subsubsection{Cost of production - $\mathrm{CP}_{\mathrm{i}}$}

The cost of opium production $(C P)$ is given by the quantity of opium destined for the Balkan route $\left(E X_{A F}\right)$ multiplied by the unitary cost to produce it $(U Z O)^{132}\left[C P=E X_{A F} \cdot U Z O\right]$. The study takes the farm-gate price as unitary production cost. ${ }^{133}$ The UNODC Afghan Opium Surveys provide this information. ${ }^{134}$ Obviously, international traffickers have to absorb the costs of the production of opium that then contribute to the estimate of the gross profit at the international trade level.

Table A 19. Cost of production of raw opium (millions of United States dollars), 2009-2012 average

\section{Low estimate}

998
Best estimate

1,092

High estimate

$\begin{array}{llcc}\text { Afghanistan } & 998 & 1,092 & 1,197\end{array}$

Note: different assumptions on per-user annual consumption of illicit opiates determine different estimates of the demand for illicit opiates in the Balkan route countries and consequently of the costs of production of raw opium.

Source: based on UNODC data.

\footnotetext{
${ }^{131}$ UNODC and Islamic Republic of Afghanistan - Ministry of Counter Narcotics, Afghanistan Opium Survey 2011 (Vienna, 2011); UNODC and Islamic Republic of Afghanistan - Ministry of Counter Narcotics, Afghan Opium Survey 2014 (Vienna, 2014).

${ }^{132}$ Claudia Costa Storti and Paul De Grauwe, "Modelling the Cocaine and Heroin Markets in the Era of Globalization and Drug Reduction Policies," March 2008.

${ }^{133}$ Ibid.

${ }^{134}$ UNODC and Islamic Republic of Afghanistan - Ministry of Counter Narcotics, Afghanistan Opium Survey 2011 (Vienna, 2011); UNODC and Islamic Republic of Afghanistan Ministry of Counter-Narcotics, Afghan Opium Survey 2014 (Vienna, 2014).
} 


\subsubsection{Total gross profit - $G P_{i}$}

On combining the four dimensions estimated above (retail, wholesale and international distribution, cost of production, and of manufacturing) it is possible to obtain the final estimate of the gross profit (see Table A 20).

Table A 20. Total gross profit (millions of United States dollars) made from illicit opiates trafficked on the Balkan route, by country/territory, 2009-2012 average

Low estimate

Albania
Austria
Belgium
Bosnia and Herzegovina
Bulgaria
Croatia
Czech Republic
Denmark
France
Germany
Greece
Hungary
Iran (Islamic Republic of)
Ireland
Italy
Kosovo
Luxembourg
fYR of Macedonia
Montenegro
Netherlands
Norway
Poland
Portugal
Romania
Serbia
Slovakia
Slovenia
Spain
Sweden
Salkerland
Singdom
Suute
Surey

\section{Balkan route}

Afghanistan

\begin{tabular}{|c|c|c|}
\hline Low estimate & Best estimate & High estimate \\
\hline 255 & 320 & 392 \\
\hline 801 & 1,007 & 1,235 \\
\hline 98 & 123 & 151 \\
\hline 32 & 40 & 49 \\
\hline 493 & 616 & 752 \\
\hline 177 & 223 & 273 \\
\hline 127 & 160 & 196 \\
\hline 387 & 486 & 597 \\
\hline 4,041 & 5,079 & 6,233 \\
\hline 2,089 & 2,625 & 3,220 \\
\hline 174 & 218 & 267 \\
\hline 41 & 51 & 63 \\
\hline 6,093 & 7,521 & 9,108 \\
\hline 534 & 672 & 824 \\
\hline 1,208 & 1,518 & 1,862 \\
\hline 20 & 25 & 31 \\
\hline 33 & 42 & 51 \\
\hline 31 & 39 & 47 \\
\hline 9 & 11 & 14 \\
\hline 148 & 183 & 223 \\
\hline 310 & 390 & 479 \\
\hline 221 & 277 & 340 \\
\hline 126 & 158 & 194 \\
\hline 107 & 135 & 165 \\
\hline 27 & 33 & 41 \\
\hline 106 & 133 & 163 \\
\hline 74 & 93 & 114 \\
\hline 571 & 717 & 880 \\
\hline 435 & 547 & 671 \\
\hline 348 & 437 & 536 \\
\hline 620 & 765 & 926 \\
\hline 2,705 & 3,399 & 4,170 \\
\hline 22,442 & 28,044 & 34,268 \\
\hline 349 & 357 & 366 \\
\hline
\end{tabular}

Note: different assumptions on per-user annual consumption of illicit opiates determine the three estimates (see Box A 10).

Source: based on UNODC data. 



\section{Annex 2. Estimating the monetary value of illicit opiate trafficking on the Balkan route}

The model outlined above elaborates the gross profit originating from the trade of Afghan opium across the Balkan route countries.

The estimate of the gross profit follows basic principles of economic accounting; consequently, it is possible to compare gross profit and GDP to gain insights into the potential economic effects of opiate trafficking in the Balkan route countries $\left(E_{i}\right) \cdot{ }^{135} \mathrm{GDP}$ measures final purchases by households, businesses and governments by summing consumption, investment, government spending and net exports. It is the best proxy for economic development and it allows the most comprehensive analyses of the impact of external events on the economy of a country as well as of a region. ${ }^{136}$

$$
E_{i}=G P_{i} / G D P_{i}
$$

\footnotetext{
${ }^{135}$ Besides the gross profit, this analysis produces, or may easily produce, other measurements, such as the turnover and the funds deriving from the opium trade available for reinvestment in the legal economy. All these measurements can be compare with the GDP in order to gain an idea of the possible impacts that opiates trafficking may have.

${ }^{136} \mathrm{~J}$. Steven Landefeld, "GDP: One of the Great Inventions of the 20th Century.," Survey of Current Business, January 1, 2000, http://www. highbeam.com/doc/1G1-62290079.html.
} 
Table A 21. Gross profit share of GDP (percentage) in Balkan route countries/territory 2009-2012 average

\begin{tabular}{|c|c|c|c|}
\hline & Low estimate & Best estimate & High estimate \\
\hline Albania & $2.08 \%$ & $2.60 \%$ & $3.19 \%$ \\
\hline Austria & $0.20 \%$ & $0.26 \%$ & $0.31 \%$ \\
\hline Belgium & $0.02 \%$ & $0.03 \%$ & $0.03 \%$ \\
\hline Bosnia and Herzegovina & $0.19 \%$ & $0.23 \%$ & $0.29 \%$ \\
\hline Bulgaria & $0.98 \%$ & $1.22 \%$ & $1.50 \%$ \\
\hline Croatia & $0.30 \%$ & $0.37 \%$ & $0.46 \%$ \\
\hline Czech Republic & $0.06 \%$ & $0.08 \%$ & $0.10 \%$ \\
\hline Denmark & $0.12 \%$ & $0.15 \%$ & $0.19 \%$ \\
\hline France & $0.15 \%$ & $0.19 \%$ & $0.24 \%$ \\
\hline Germany & $0.06 \%$ & $0.08 \%$ & $0.09 \%$ \\
\hline Greece & $0.06 \%$ & $0.08 \%$ & $0.09 \%$ \\
\hline Hungary & $0.03 \%$ & $0.04 \%$ & $0.05 \%$ \\
\hline Iran (Islamic Republic of) & $1.34 \%$ & $1.66 \%$ & $2.01 \%$ \\
\hline Ireland & $0.25 \%$ & $0.31 \%$ & $0.38 \%$ \\
\hline Italy & $0.06 \%$ & $0.07 \%$ & $0.09 \%$ \\
\hline Kosovo & $0.33 \%$ & $0.41 \%$ & $0.50 \%$ \\
\hline Luxembourg & $0.06 \%$ & $0.08 \%$ & $0.10 \%$ \\
\hline fYR of Macedonia & $0.32 \%$ & $0.40 \%$ & $0.49 \%$ \\
\hline Montenegro & $0.22 \%$ & $0.27 \%$ & $0.33 \%$ \\
\hline Netherlands & $0.02 \%$ & $0.02 \%$ & $0.03 \%$ \\
\hline Norway & $0.07 \%$ & $0.09 \%$ & $0.11 \%$ \\
\hline Poland & $0.05 \%$ & $0.06 \%$ & $0.07 \%$ \\
\hline Portugal & $0.06 \%$ & $0.07 \%$ & $0.09 \%$ \\
\hline Romania & $0.06 \%$ & $0.08 \%$ & $0.10 \%$ \\
\hline Serbia & $0.07 \%$ & $0.08 \%$ & $0.10 \%$ \\
\hline Slovakia & $0.12 \%$ & $0.15 \%$ & $0.18 \%$ \\
\hline Slovenia & $0.15 \%$ & $0.19 \%$ & $0.24 \%$ \\
\hline Spain & $0.04 \%$ & $0.05 \%$ & $0.06 \%$ \\
\hline Sweden & $0.09 \%$ & $0.11 \%$ & $0.14 \%$ \\
\hline Switzerland & $0.06 \%$ & $0.07 \%$ & $0.09 \%$ \\
\hline Turkey & $0.09 \%$ & $0.11 \%$ & $0.13 \%$ \\
\hline United Kingdom & $0.11 \%$ & $0.14 \%$ & $0.18 \%$ \\
\hline Balkan route & $0.12 \%$ & $0.15 \%$ & $0.19 \%$ \\
\hline Afghanistan & $2.09 \%$ & $2.14 \%$ & $2.19 \%$ \\
\hline
\end{tabular}

Note: different assumptions on per-user annual consumption of illicit opiates determine the three estimates (see Box A 10).

Source: based on UNODC and the World Bank data. 


\section{Annex 3. Estimating purities}

Purity levels are fundamental for estimating the size of the opiate economy and understanding how it works. Despite the centrality of this class of data and international efforts in fighting illicit opiate production and trafficking, purity series are not available in most countries. ${ }^{137}$ Even consumers, who are able to report how much they spend or how frequently they inject, smoke or inhale drugs, are usually unware of the purity of the substances that they buy. ${ }^{138}$ The problem is reflected in retail purity levels that vary enormously in certain markets.

UNODC provides the most comprehensive series of data on heroin purity currently available. ${ }^{139}$ However, UNODC data are also incomplete or incoherent for some countries, ${ }^{140}$ or for some years. Given the need to perform cross-country analyses based on multiple years (2009-2012 averages), the present study imputes missing data according to the interpolation criteria outlined below (see Box A 12). ${ }^{141}$

The imputation process yields a simple average of the purity data for all Balkan route countries for 2009-2012 (see Table A 22). These values are the bases for the estimates of purity-adjusted prices (see Annex 4) and seizures (see Annex.1.2 and Box A 11).

\section{Box A 12. Interpolation criteria}

The UNODC Delta ARQ database presents three estimates of the purity - minimum registered value $(m)$, maximum registered value $(M)$, and typical value $(T)$ - for both a street level (ST_pu) and a wholesale level (WS_pu). ${ }^{142}$ Whenever data are missing for a given country in one more year, the current study imputes the missing data according to the following criteria:

- $T$ is missing; $M$ and $m$ are reported in year $y(2009-2012)$, then $T_{i y}=\left(\overline{M_{i y} ; m_{i y}}\right)$.

- A datum is missing in year $y$, but it is available for two or three years $(z)$ different from $y$. The datum is imputed by the weighted average of the data of the available years. The temporal distance between the missing datum and the available one gives the weights $\left(w_{z}\right)$. Weights are designed to sum to 1 and to halve every additional year of distance from the missing datum [ex. $T_{i y}$ is missing: $T_{i y}=\sum_{z=1}^{z} T_{i z} w_{z}$ ]. - A datum is available in year $y$, but it is not available in any other year $(z)$. The missing datum is assumed to change in time as the equivalent datum changes in the countries $J$ linked to $i$ in the opiate network (see Annex.1.2). The relative relevance of the $J$ countries is given by weights $(s)$, which depends on the shares of illicit opiates exported to and from the country considered $(i)$ [e.g. $m_{\mathrm{i} z}$ is missing, $m_{i y}$ is available: $\left.m_{i z}=\sum_{j=1}^{j}\left[\left(m_{j z}-m_{j y}\right) / m_{j y} s_{j i}\right] m_{i y}\right] \cdot{ }^{143}$

- Two data among $m, M$, and $T$ are missing for the entire period; the third is available. The missing data are imputed by the relative difference with respect to the available one in the countries $J$ linked to $i$ in the opiate network (see Annex.1.2). The relative relevance of the $J$ countries is given by weight $(s)$, which depends on the shares of illicit opiates exported to and from the country considered $(i)$ [ex. $M_{i y}$ is missing, $m_{i y}$ is available: $M_{i y}=\left(\sum_{j=1}^{j} M_{j y} s_{j i} / \sum_{j=1}^{j} m_{j y} s_{j i}\right) m_{i y}$. Equivalently $T_{i y}$ would be: $\left.\left.T_{i y}=\left(\sum_{j=1}^{j} T_{j y} s_{j i} / \sum_{j=1}^{J} m_{j y} s_{j i}\right) m_{i y}\right)\right]$

- A datum is available at the street level (ST_pu), but not at the wholesale level (WS_pu), or vice versa. The missing datum is imputed by the weighted average of the value in the linked countries adjusted by the per cent difference between the value at the available level in the country $(i)$ and in the linked countries

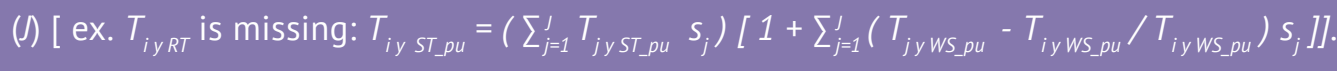

\footnotetext{
${ }^{137}$ Kilmer and Pacula, "Estimating the Size of the Illegal Drug Market: A Demand-Side Approach"; UNODC, The Global Afghan Opium Trade, 2011.

${ }^{138}$ Paoli, Greenfield, and Reuter, The World Heroin Market, 95.

${ }^{139}$ UNODC, Drug Situation Analysis Report - Islamic Republic of Iran (Vienna, 2011), https://www.paris-pact.net/upload/8adad0c19394d428589a714af3f 14cad.pdf; UNODC, Delta Annual Reports Questionnaire Database, 2014.

${ }^{140}$ Whenever the reported or imputed purity levels at street level are higher than those at wholesale level, the data are inverted.

${ }^{141} \mathrm{i}$ indicates the country considered; $\mathrm{j}$ indicates a country linked to $\mathrm{i}$ through imports or exports.

${ }^{142}$ UNODC, Delta Annual Reports Questionnaire Database, 2014.

${ }^{143}$ In no cases are Balkan route countries included in the calculation of missing values, regardless of their links. The Islamic Republic of Iran does not concur with the estimates of the missing values.
} 
- No data are available for the country considered for the period considered. Each missing datum is imputed by averaging the data of the country exporting to the country considered and the data of the country importing from the country considered. Weights $(s)$ depend on the shares of illicit opiates exported to and from the country considered. Both importer weights $(s o)$ and exporter weights $(s x)$ sum to 1 [e.g. $M_{i y}$ is missing: $\left.M_{i y}=\left(\overline{\sum_{j o=1}^{J O} M_{j o y} s o_{j 0} ; \sum_{j x=1}^{J X} M_{j x y} s x_{j x}}\right)\right]$.

Table A 22. Purity levels from Delta ARQ database (percentages), Balkan route countries/territory, 2009-2012 averages

\begin{tabular}{|c|c|c|c|c|c|c|}
\hline & \multicolumn{3}{|c|}{ Street level - ST_pu } & \multicolumn{3}{|c|}{ Wholesale level - WS_pu } \\
\hline & $\begin{array}{c}\text { Minimum } \\
m_{s T_{-} p u}\end{array}$ & $\begin{array}{c}\text { Typical } \\
T_{\text {sT_pu }}\end{array}$ & $\begin{array}{l}\text { Maximum } \\
M_{\text {ST_pu }}\end{array}$ & $\begin{array}{l}\text { Minimum } \\
m_{w s \_p u}\end{array}$ & $\begin{array}{c}\text { Typical } \\
T_{\text {ws_pu }}\end{array}$ & $\begin{array}{l}\text { Maximum } \\
M_{w s \_p u}\end{array}$ \\
\hline Albania & $1 \%$ & $5 \%$ & $13 \%$ & $27 \%$ & $37 \%$ & $50 \%$ \\
\hline Austria & $0 \%$ & $7 \%$ & $43 \%$ & $0 \%$ & $23 \%$ & $47 \%$ \\
\hline Belgium & $1 \%$ & $20 \%$ & $62 \%$ & $5 \%$ & $44 \%$ & $71 \%$ \\
\hline Bosnia and Herzegovina & $3 \%$ & $22 \%$ & $50 \%$ & $7 \%$ & $24 \%$ & $56 \%$ \\
\hline Bulgaria & $1 \%$ & $13 \%$ & $48 \%$ & $15 \%$ & $41 \%$ & $60 \%$ \\
\hline Croatia & $1 \%$ & $14 \%$ & $45 \%$ & $1 \%$ & $16 \%$ & $54 \%$ \\
\hline Czech Republic & $2 \%$ & $14 \%$ & $39 \%$ & $9 \%$ & $28 \%$ & $60 \%$ \\
\hline Denmark & $5 \%$ & $17 \%$ & $42 \%$ & $22 \%$ & $50 \%$ & $72 \%$ \\
\hline France & $2 \%$ & $9 \%$ & $37 \%$ & $19 \%$ & $18 \%$ & $55 \%$ \\
\hline Germany & $0 \%$ & $17 \%$ & $64 \%$ & $2 \%$ & $44 \%$ & $67 \%$ \\
\hline Greece & $0 \%$ & $14 \%$ & $70 \%$ & $8 \%$ & $40 \%$ & $76 \%$ \\
\hline Hungary & $7 \%$ & $21 \%$ & $43 \%$ & $7 \%$ & $25 \%$ & $45 \%$ \\
\hline Iran (Islamic Republic of) & $7 \%$ & $11 \%$ & $15 \%$ & $20 \%$ & $58 \%$ & $96 \%$ \\
\hline Ireland & $10 \%$ & $27 \%$ & $63 \%$ & $12 \%$ & $38 \%$ & $72 \%$ \\
\hline Italy & $3 \%$ & $24 \%$ & $56 \%$ & $13 \%$ & $28 \%$ & $74 \%$ \\
\hline Kosovo & $1 \%$ & $26 \%$ & $61 \%$ & $3 \%$ & $44 \%$ & $72 \%$ \\
\hline Luxembourg & $0 \%$ & $16 \%$ & $49 \%$ & $13 \%$ & $36 \%$ & $66 \%$ \\
\hline fYR of Macedonia & $1 \%$ & $22 \%$ & $57 \%$ & $3 \%$ & $47 \%$ & $71 \%$ \\
\hline Montenegro & $1 \%$ & $16 \%$ & $35 \%$ & $16 \%$ & $35 \%$ & $57 \%$ \\
\hline Netherlands & $1 \%$ & $37 \%$ & $63 \%$ & $4 \%$ & $47 \%$ & $73 \%$ \\
\hline Norway & $1 \%$ & $14 \%$ & $66 \%$ & $2 \%$ & $44 \%$ & $67 \%$ \\
\hline Poland & $8 \%$ & $19 \%$ & $32 \%$ & $21 \%$ & $27 \%$ & $41 \%$ \\
\hline Portugal & $1 \%$ & $22 \%$ & $59 \%$ & $2 \%$ & $27 \%$ & $66 \%$ \\
\hline Romania & $6 \%$ & $25 \%$ & $44 \%$ & $25 \%$ & $38 \%$ & $51 \%$ \\
\hline Serbia & $1 \%$ & $31 \%$ & $66 \%$ & $4 \%$ & $42 \%$ & $73 \%$ \\
\hline Slovakia & $3 \%$ & $8 \%$ & $12 \%$ & $32 \%$ & $44 \%$ & $57 \%$ \\
\hline Slovenia & $3 \%$ & $15 \%$ & $44 \%$ & $7 \%$ & $22 \%$ & $44 \%$ \\
\hline Spain & $1 \%$ & $31 \%$ & $69 \%$ & $4 \%$ & $43 \%$ & $79 \%$ \\
\hline Sweden & $8 \%$ & $22 \%$ & $60 \%$ & $44 \%$ & $42 \%$ & $80 \%$ \\
\hline Switzerland & $6 \%$ & $14 \%$ & $27 \%$ & $11 \%$ & $36 \%$ & $60 \%$ \\
\hline Turkey & $0 \%$ & $44 \%$ & $79 \%$ & $0 \%$ & $54 \%$ & $80 \%$ \\
\hline United Kingdom & $2 \%$ & $26 \%$ & $52 \%$ & $24 \%$ & $50 \%$ & $72 \%$ \\
\hline Afghanistan & $8 \%$ & $19 \%$ & $32 \%$ & $20 \%$ & $52 \%$ & $96 \%$ \\
\hline
\end{tabular}

Source: based on UNODC data. 


\section{Annex 4. Estimating prices}

The Delta ARQ database of UNODC provides six levels of prices per country (minimum ( $m$ ), typical $(t)$ and maximum $(M)$ price at the street (ST_pr) and at the wholesale (WS_pr) level). Additional information concerning prices in Afghanistan come from the UNODC Afghan Opium Surveys. ${ }^{144}$

This study estimates possible missing data on prices by applying the same methodology as used for missing data on purities (see Annex 3 and Box A 12). The averages of the data on prices in 2009-2012 taken from the Delta ARQ database are the bases for the estimate of the purity-adjusted international trade (see Annex.4.1), wholesale (see Annex.4.2), and retail prices (see Annex.4.3) actually used to estimate the gross profit (see Table A 23).

Table A 23. Heroin prices from Delta ARQ database (Unites States dollars per kilogram), Balkan route countries/ territory, 2009-2012 averages

\begin{tabular}{|c|c|c|c|c|c|c|}
\hline & \multicolumn{3}{|c|}{ Street level - ST_pr } & \multicolumn{3}{|c|}{ Wholesale level - WS_pr } \\
\hline & $\begin{array}{l}\text { Minimum } \\
m_{\text {ST_pr }}\end{array}$ & $\begin{array}{c}\text { Typical } \\
T_{S T_{p} p r}\end{array}$ & $\begin{array}{c}\text { Maximum } \\
M_{S T, p r}\end{array}$ & $\begin{array}{l}\text { Minimum } \\
m_{w s_{\_} p r}\end{array}$ & $\begin{array}{l}\text { Typical } \\
T_{\text {WS_pr }}\end{array}$ & $\begin{array}{c}\text { Maximum } \\
M_{w s \_p r}\end{array}$ \\
\hline Albania & 28,350 & 30,728 & 33,750 & 18,152 & 20,347 & 23,518 \\
\hline Austria & 39,330 & 62,216 & 78,660 & 28,979 & 36,322 & 45,851 \\
\hline Belgium & 10,502 & 35,502 & 105,198 & 9,698 & 15,608 & 21,086 \\
\hline Bosnia and Herzegovina & 28,047 & 33,735 & 39,422 & 18,973 & 19,888 & 22,313 \\
\hline Bulgaria & 42,977 & 45,435 & 47,893 & 19,357 & 28,077 & 36,797 \\
\hline Croatia & 67,606 & 74,367 & 81,128 & 18,930 & 22,407 & 25,884 \\
\hline Czech Republic & 40,213 & 53,249 & 113,213 & 25,606 & 26,968 & 46,973 \\
\hline Denmark & 72,463 & 104,466 & 172,700 & 27,004 & 45,007 & 54,009 \\
\hline France & 36,150 & 50,644 & 64,143 & 9,956 & 13,706 & 20,876 \\
\hline Germany & 24,907 & 53,435 & 96,734 & 17,920 & 32,526 & 40,520 \\
\hline Greece & 11,462 & 29,495 & 47,528 & 12,075 & 17,326 & 22,577 \\
\hline Hungary & 17,442 & 50,590 & 131,877 & 20,056 & 24,067 & 29,415 \\
\hline Iran (Islamic Republic of) & 10,177 & 20,150 & 47,424 & 1,687 & 4,597 & 8,171 \\
\hline Ireland & 172,291 & 202,143 & 279,189 & 40,568 & 40,568 & 67,613 \\
\hline Italy & 47,646 & 56,262 & 64,948 & 27,071 & 31,052 & 35,033 \\
\hline Kosovo & 28,800 & 37,606 & 53,025 & 19,057 & 22,150 & 26,293 \\
\hline Luxembourg & 34,329 & 80,192 & 154,158 & 12,902 & 19,398 & 26,229 \\
\hline fYR of Macedonia & 19,381 & 25,304 & 33,742 & 12,109 & 13,127 & 14,396 \\
\hline Montenegro & 24,831 & 27,873 & 34,841 & 13,988 & 15,401 & 17,197 \\
\hline Netherlands & 27,417 & 54,825 & 89,280 & 12,072 & 37,917 & 51,119 \\
\hline Norway & 98,152 & 141,093 & 184,035 & 31,556 & 40,800 & 51,413 \\
\hline Poland & 20,348 & 46,880 & 80,797 & 12,386 & 26,452 & 38,835 \\
\hline Portugal & 22,913 & 49,218 & 89,203 & 27,208 & 29,806 & 34,010 \\
\hline Romania & 48,329 & 56,319 & 64,309 & 20,603 & 25,345 & 30,087 \\
\hline Serbia & 16,387 & 26,089 & 34,169 & 18,507 & 20,379 & 23,380 \\
\hline Slovakia & 28,588 & 55,668 & 82,759 & 16,192 & 27,804 & 36,783 \\
\hline Slovenia & 33,788 & 50,509 & 77,701 & 14,857 & 21,734 & 30,356 \\
\hline Spain & 39,190 & 79,540 & 133,759 & 26,237 & 43,628 & 56,758 \\
\hline Sweden & 86,367 & 204,836 & 433,397 & 33,777 & 43,712 & 56,196 \\
\hline Switzerland & 20,360 & 56,401 & 122,160 & 18,782 & 28,078 & 39,575 \\
\hline Turkey & 8,992 & 39,047 & 69,102 & 3,728 & 18,454 & 37,239 \\
\hline United Kingdom & 48,920 & 64,589 & 109,502 & 27,891 & 36,143 & 44,219 \\
\hline Afghanistan & 6,108 & 6,108 & 6,108 & 1,768 & 3,035 & 5,120 \\
\hline
\end{tabular}

Source: based on UNODC data.

${ }^{144}$ UNODC and Islamic Republic of Afghanistan - Ministry of Counter Narcotics, Afghanistan Opium Survey (Vienna, 2009, 2010, 2011, 2012). 


\section{Annex. 4.1. International trade prices}

International trade prices are the prices at which transnational traffickers trade illicit opiates. They are not specific to a single country but rather to each pair of countries between which opiate trafficking takes place. The study estimates a range of purity-adjusted international trade prices for each country; and then combines the ranges of prices of the countries trading illicit opiates with each other to determine the specific exchange price at which the transactions occur.

The averages of prices and purity levels in 2009-2012 collected from the Delta ARQ database are combined as follows to obtain three purity-adjusted international trade prices for each country:

- The minimum purity-adjusted international trade price $\left(p r_{i j t}{ }^{m}\right)$ is obtained by adjusting the minimum price at wholesale level $\left(m_{\text {ws pr }}\right)$ by the maximum purity at wholesale level $\left.\left[p r_{i i t}{ }^{m}=m_{\text {ws pr }} / M_{\text {ws pu }}\right)\right]$ (see Table A 24). - The typical purity-adjusted international trade price $\left(p r_{i i t}{ }^{t}\right)$ is obtained by adjusting the typical price at the wholesale level by the average between the typical $\left(T_{\text {ws_pu }}\right)$ and the maximum purity $\left(M_{\text {ws_pu }}\right)$ at the wholesale level $\left[p r_{i i t}{ }^{t}=m_{\text {w__pr }} /\left(\overline{M_{\text {ws_pu }} ; T_{\text {ws_pu }}}\right)\right]$ (see Table A 24).

- The maximum purity-adjusted international trade price $\left(\mathrm{pr}_{i i t}{ }^{M}\right)$ is obtained by adjusting the maximum price at the wholesale level $\left(M_{\text {w__pr }}\right)$ by the typical purity at the wholesale level $\left(T_{\text {ws_pu }}\right)\left[p r_{i i t}{ }^{M}=M_{\text {ws pr }} / T_{\text {ws } p \text { pu }}\right]$ (see Table A 24).

The estimate of the actual exchange price $\left(p r_{i j \text { exc }}\right)$ at which the exporting country $(j)$ and an importing country $(i)$ exchange illicit opiates depends on two conditions describing the relation between the ranges of purity-adjusted international trade prices of the two countries:

1. The average of the typical purity-adjusted international trade prices of the two countries is included in both the two national ranges: $\left[p r_{j i t}{ }^{m} \leqslant\left(\overline{p r_{j i t}{ }^{t} ; p r_{i i t}{ }^{t}}\right) \leqslant p r_{j i t}{ }^{M} \wedge p r_{i i t}{ }^{m} \leqslant\left(\overline{p r_{j i t}{ }^{t} ; p r_{i i t}{ }^{t}}\right) \leqslant p r_{i i t}{ }^{M}\right]$.

2. The average of the typical purity-adjusted international trade prices of the two countries is higher than the average importing price of the exporting country

- $\left[\left(\overline{p r_{j i t}{ }^{t} ; p r_{i i t}{ }^{t}}\right) \geqslant \sum_{k=i}^{K} p r_{j k e x c} / K\right]$,

where $k$ is a country exporting illicit opiates to the country $j$ and $K$ is the total number of $k$ countries exporting to $j$.

If the two conditions hold simultaneously, the average of the typical purity-adjusted international trade prices of $\mathrm{i}$ and $\mathrm{j}$ is taken as the exchange price between the two countries: $p r_{i j e x c}=\left(\overline{p r_{j i t}{ }^{t} ; p r_{i t}{ }^{t}}\right)$.

If only condition 1 holds, then the exchange price is the maximum purity-adjusted international trade price of the exporter $\left(p r_{j i t}{ }^{M}\right)$, if the average of the typical prices is higher than the maximum price of the exporting country, while it is the minimum price of the importing country $\left(\mathrm{pr}_{i i t}{ }^{\mathrm{m}}\right)$ if the average is lower than the minimum of the importing country:

$$
\begin{gathered}
p r_{i j e x c}=p r_{j i t}{ }^{M} \text { if }\left(\overline{p r_{j i t}{ }^{t} ; p r_{i i t}{ }^{t}}\right) \geqslant p r_{j i t}{ }^{M} V \\
p r_{i j e x c}=p r_{i i t}{ }^{m} \text { if }\left(\overline{p r_{j i t}{ }^{t} ; p r_{i i t}{ }^{t}}\right) \leqslant p r_{i i t}{ }^{m}
\end{gathered}
$$

If only condition 2 holds, then the exchange price is the average price at import for the exporter increased by 10 per cent $\left[t p_{i j}=\left(\sum_{k=i}^{K} t p_{j k} / K\right)(1+0.1)\right]$ where $k$ is a country exporting illicit opiates to the country $j$, which, in turn, exports to country $i$.

The study excludes from the trafficking network pairs of countries whose ranges of purity-adjusted international trade prices do not overlap (see Annex 1.2.1). 
Table A 24. Database purity adjusted prices at the wholesale level (United States dollars per kilogram of pure heroin equivalent), Balkan route countries/territory, 2009-2012 average

\begin{tabular}{|c|c|c|c|}
\hline & Minimum price $p r_{i i t}{ }^{m}$ & Typical price $p r_{i i t}{ }^{t}$ & Maximum price $p r_{i i t}{ }^{M}$ \\
\hline Albania & 36,304 & 47,045 & 64,432 \\
\hline Austria & 61,944 & 103,410 & 195,411 \\
\hline Belgium & 13,686 & 27,173 & 47,904 \\
\hline Bosnia and Herzegovina & 33,743 & 49,546 & 92,769 \\
\hline Bulgaria & 32,533 & 55,736 & 89,204 \\
\hline Croatia & 34,829 & 64,157 & 166,992 \\
\hline Czech Republic & 42,417 & 61,046 & 167,847 \\
\hline Denmark & 37,493 & 73,727 & 107,872 \\
\hline France & 18,204 & 39,079 & 117,947 \\
\hline Germany & 26,866 & 58,830 & 92,354 \\
\hline Greece & 15,795 & 29,799 & 56,679 \\
\hline Hungary & 44,755 & 68,641 & 116,209 \\
\hline Iran (Islamic Republic of) & 1,757 & 5,970 & 14,088 \\
\hline Ireland & 56,738 & 74,130 & 178,163 \\
\hline Italy & 36,373 & 60,350 & 123,009 \\
\hline Kosovo & 26,523 & 38,207 & 59,626 \\
\hline Luxembourg & 19,626 & 37,979 & 72,038 \\
\hline fYR of Macedonia & 17,066 & 22,341 & 30,913 \\
\hline Montenegro & 24,435 & 33,512 & 49,602 \\
\hline Netherlands & 16,511 & 62,960 & 107,997 \\
\hline Norway & 46,960 & 73,466 & 117,180 \\
\hline Poland & 30,490 & 78,741 & 146,203 \\
\hline Portugal & 41,386 & 63,979 & 123,972 \\
\hline Romania & 40,229 & 56,670 & 78,693 \\
\hline Serbia & 25,441 & 35,637 & 56,166 \\
\hline Slovakia & 28,221 & 54,781 & 83,341 \\
\hline Slovenia & 33,526 & 65,208 & 135,853 \\
\hline Spain & 33,202 & 71,216 & 130,477 \\
\hline Sweden & 41,986 & 71,258 & 133,048 \\
\hline Switzerland & 31,174 & 58,497 & 110,700 \\
\hline Turkey & 4,640 & 27,415 & 68,587 \\
\hline United Kingdom & 38,737 & 59,081 & 87,824 \\
\hline Afghanistan & 1,842 & 4,101 & 9,845 \\
\hline
\end{tabular}

Source: based on UNODC data.

\section{Annex. 4.2. Wholesale prices}

The wholesale level refers to the handling of large quantities of illicit opiates domestically. This study estimates two different wholesale prices for each country. The highest is the price at which wholesalers sell drugs to national retailers $\left(p r_{i w h}{ }^{s}\right)$. The lowest is the price at which the exchange of illicit opiates between traffickers and wholesalers takes place $\left(p r_{i w h}{ }^{p}\right)$ (see Table A 25). 
The price at which wholesalers resell opiates to retailers $\left(p r_{i w h}{ }^{s}\right)$ is calculated taking the average of the minimum price at the street level $\left(m_{\text {ST_pr }}\right)$ adjusted for the typical purity at the street level $\left(T_{\text {ST_pu }}\right)$ and the typical price at the wholesale level $\left(T_{\text {w__pr }}\right)$ adjusted for maximum purity at the wholesale level $\left(M_{\text {w__pr }}\right)$ (see Table A 22 and Table A 23).

The price at which wholesalers purchase opiates $\left(p r_{i w h}{ }^{p}\right)$ is given by the average between the average importing price and the price at which wholesalers re-sell opiates to retailers as described above. The average importing price depends on the international exchange price, the calculus of which is described in the previous section (see Annex.4.1).

Table A 25. Purity-adjusted wholesale prices (United States dollars per kilogram of pure heroin equivalent), Balkan route countries/territory, 2009-2012 average

\begin{tabular}{|c|c|c|}
\hline & $\begin{array}{l}\text { Wholesale purchasing price } \\
\qquad \operatorname{pr}_{i w h}^{p}\end{array}$ & $\begin{array}{l}\text { Wholesale selling price } \\
\operatorname{pr}_{i w h} s\end{array}$ \\
\hline Albania & 176,516 & 330,634 \\
\hline Austria & 237,169 & 391,695 \\
\hline Belgium & 35,726 & 50,197 \\
\hline Bosnia and Herzegovina & 77,783 & 110,418 \\
\hline Bulgaria & 126,424 & 213,141 \\
\hline Croatia & 191,780 & 325,380 \\
\hline Czech Republic & 142,667 & 226,396 \\
\hline Denmark & 168,829 & 273,522 \\
\hline France & 149,499 & 267,332 \\
\hline Germany & 85,344 & 118,688 \\
\hline Greece & 50,447 & 70,122 \\
\hline Hungary & 78,720 & 99,144 \\
\hline Iran (Islamic Republic of) & 29,771 & 53,302 \\
\hline Ireland & 228,294 & 411,627 \\
\hline Italy & 106,287 & 160,809 \\
\hline Kosovo & 59,313 & 84,924 \\
\hline Luxembourg & 90,294 & 146,357 \\
\hline fYR of Macedonia & 46,982 & 60,511 \\
\hline Montenegro & 72,271 & 104,708 \\
\hline Netherlands & 69,768 & 90,999 \\
\hline Norway & 236,360 & 405,008 \\
\hline Poland & 92,270 & 127,557 \\
\hline Portugal & 86,029 & 114,832 \\
\hline Romania & 94,958 & 135,429 \\
\hline Serbia & 48,120 & 54,729 \\
\hline Slovakia & 133,151 & 209,834 \\
\hline Slovenia & 115,819 & 182,075 \\
\hline Spain & 82,085 & 127,444 \\
\hline Sweden & 159,658 & 262,813 \\
\hline Switzerland & 93,156 & 127,040 \\
\hline Turkey & 26,979 & 44,594 \\
\hline United Kingdom & 82,412 & 137,181 \\
\hline Afghanistan & 10,635 & 21,270 \\
\hline
\end{tabular}

Source: based on UNODC data. 


\section{Annex 4.3. Retail prices}

The retail price is the price at which the study assumes final consumers purchase illicit opiates; it enters the calculation of the gross profit at the retail level (see Annex 1.3.1).

The purity-adjusted retail price $\left(p r_{i r t}\right)$ is obtained by dividing the 2009-2012 average of the typical price at the street level $\left(T_{\text {W__pr }}\right)$ by the 2009-2012 average of typical purity at the street level $\left(T_{\text {ST_pu }}\right)\left[p r_{i r t}=T_{i \text { w__pr }} / T_{\text {ist_pu }}\right]$ (see Table A 26). Considering the registered retail prices and the opium to heroin conversion factors, the purity-adjusted price of opium in the Islamic Republic of Iran is $\$ 17,760$ per kilogram of opium, while the price in Afghanistan is $\$ 9,435$ per kilogram. ${ }^{145}$

Table A 26. Purity-adjusted retail price (United States dollars per kilogram of pure heroin equivalent), Balkan route countries/territory, 2009-2012 average

\begin{tabular}{|c|c|c|c|}
\hline Country & $\begin{array}{l}\text { National purity- } \\
\text { adjusted retail price }\end{array}$ & Country & $\begin{array}{l}\text { National purity-adjusted } \\
\text { retail price }\end{array}$ \\
\hline Albania & 646,895 & Luxembourg & 515,494 \\
\hline Austria & 930,131 & FYR of Macedonia & 117,651 \\
\hline Belgium & 177,445 & Montenegro & 179,390 \\
\hline Bosnia and Herzegovina & 154,039 & Netherlands & 147,976 \\
\hline Bulgaria & 356,355 & Norway & 995,952 \\
\hline Croatia & 532,144 & Portugal & 227,035 \\
\hline Czech Republic & 377,318 & Romania & 223,933 \\
\hline Denmark & 633,126 & Serbia & 84,842 \\
\hline France & 583,788 & Slovakia & 654,923 \\
\hline Germany & 311,122 & Slovenia & 341,279 \\
\hline Greece & 215,033 & Spain & 252,507 \\
\hline Hungary & 238,068 & Sweden & 931,075 \\
\hline Iran (Islamic Republic of) & 183,184 & Switzerland & 397,193 \\
\hline Ireland & 756,863 & United Kingdom & 246,288 \\
\hline Italy & 234,524 & Poland & 250,923 \\
\hline Kosovo & 143,923 & Turkey & 89,457 \\
\hline Afghanistan & 32,695 & & \\
\hline
\end{tabular}

Source: based on UNODC data.

${ }^{145}$ UNODC,Delta Annual Reports Questionnaire Database, 2014. 
